\title{
AVALIAÇÃO DO IOGURTE PRODUZIDO COM LEITE CONTENDO DIFERENTES NÍVEIS DE CÉLULAS SOMÁTICAS
}

\section{ANDREZZA MARIA FERNANDES}

Dissertação de Mestrado apresentada à

Comissão de Pós-Graduação da Faculdade de Zootecnia e Engenharia de Alimentos da USP, como parte dos requisitos para a obtenção do Título de Mestre em Zootecnia, na área de 


\section{AVALIAÇÃO DO IOGURTE PRODUZIDO COM LEITE CONTENDO DIFERENTES NÍVEIS DE CÉLULAS SOMÁTICAS}

\section{ANDREZZA MARIA FERNANDES}

Dissertação de Mestrado apresentada à

Comissão de Pós-Graduação da Faculdade de Zootecnia e Engenharia de Alimentos da USP, como parte dos requisitos para a obtenção do Título de Mestre em Zootecnia, na área de 


\section{FICHA CATALOGRÁFICA}

preparada pela

Biblioteca da Faculdade de Zootecnia e Engenharia de Alimentos da Universidade de São Paulo

\begin{tabular}{|l|}
\hline F636a \\
Fernandes, Andrezza Maria \\
Avaliação do iogurte produzido com leite contendo diferentes \\
níveis de células somáticas/ Andrezza Maria Fernandes - \\
Pirassununga, 2003. \\
87 p. \\
Dissertação (Mestrado) -- Faculdade de Zootecnia e \\
Engenharia de Alimentos, Universidade de São Paulo. \\
Departamento de Zootecnia \\
Área de concentração: Qualidade e Produtividade Animal. \\
Orientador: Prof. Dr. Carlos Augusto Fernandes de Oliveira. \\
Unitermos: 1. Células somáticas, contagem 2. Iogurte \\
3. Leite, qualidade 4. Proteólise, lipólise, viscosidade I. Título. \\
\end{tabular}




\section{DEDICATÓRIA}

"Aprender é a única coisa de que a mente nunca se cansa, nunca tem medo e nunca se arrepende."

(Leonardo da Vinci)

A minha mãe Valéria,

pelo incentivo e por toda a dedicação.

Ao Luiz,

pelo carinho e apoio. 


\section{AGRADECIMENTOS}

Ao Prof. Dr. Carlos Augusto Fernandes de Oliveira pela orientação, incentivo e exemplo de profissionalismo.

À FAPESP pelo auxílio financeiro durante a Iniciação Científica e o Mestrado.

À Comissão de Pós-Graduação da FZEA.

À Faculdade de Zootecnia e Engenharia de Alimentos da Universidade de São Paulo pela estrutura disponibilizada aos seus estudantes.

À Clínica do leite (ESALQ/ USP) pela agilização nos resultados de CCS.

À Roice pelo imprescindível auxílio durante o experimento e pela amizade.

Ao Fábio, Evanilson, Osvaldo e Dorival pela colaboração nas atividades no laticínio.

À Juliana, Coelho, André, Zé, Valmir, Tadeu e Marco pelo auxílio na obtenção do leite.

Ao Apolinário, Marcos e Anderson pela colaboração no uso de alguns equipamentos.

À Érica e Conceição pelo suporte administrativo.

Aos meus familiares, especialmente minha avó Edith.

Aos graduandos: Aline e Suedem, pelo auxílio nos processamentos; Marina e Natália, pela colaboração no experimento piloto; Daniela e Andréa, pelo convívio na Faculdade.

Aos amigos Samantha, Marina, Laura, Fernanda, Sabrina, Fábio Garcia, Fábio Kaneto, Helena, Karine, Aya, Nídia e Sandra.

Aos Pós Graduandos: Evelise, Gustavo, Arlindo, Bruno, Mário, Flávio, Márcia Coalho, Rodrigo, Otaviano e José Henrique.

A todos que colaboraram na realização desse experimento. 


\section{SUMÁRIO}

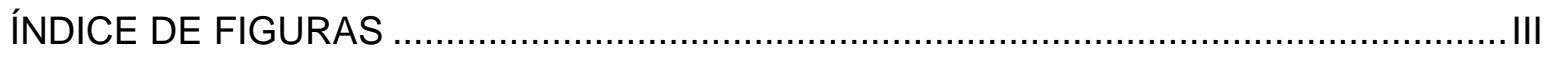

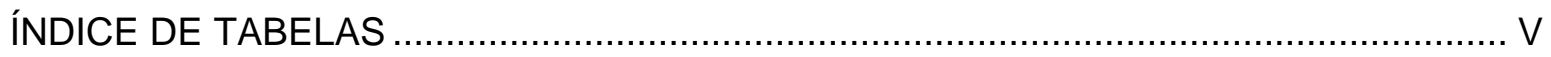

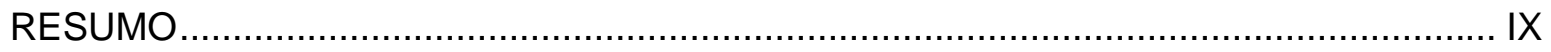

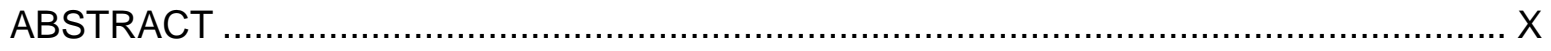

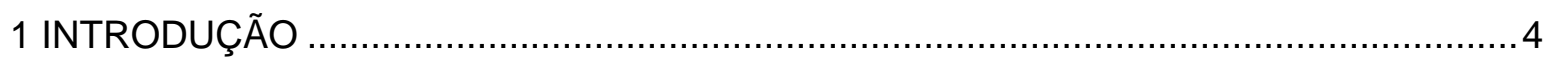

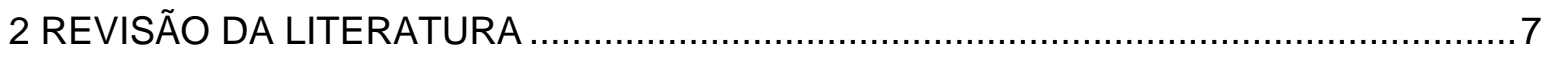

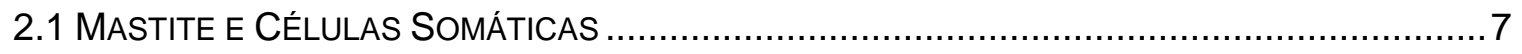

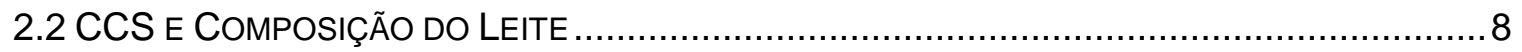

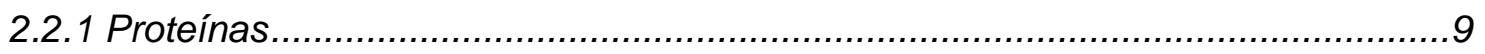

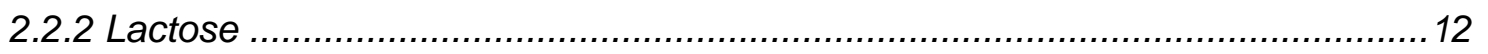

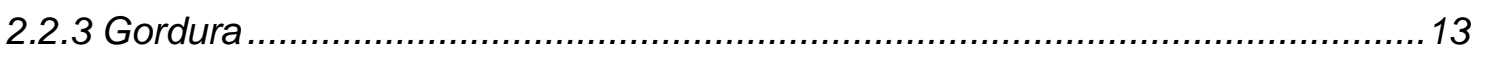

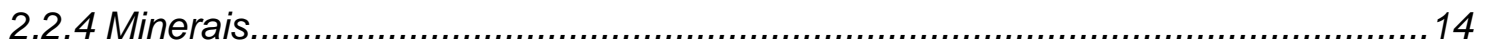

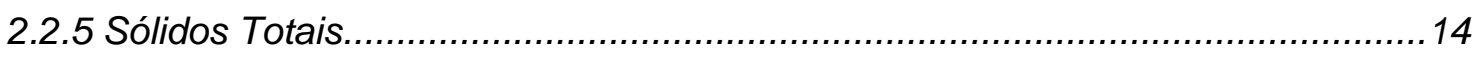

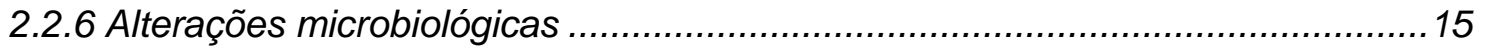

2.3 CCS E QUALIDADE DOS PRODUTOS LÁCTEOS....................................................

2.3.1 Leites Pasteurizado e Ultra-High Temperature (UHT) .................................16

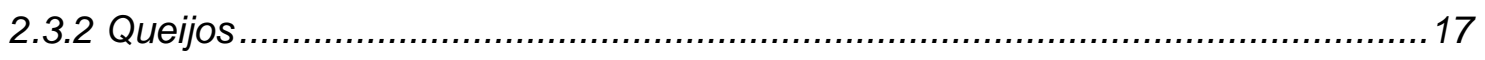

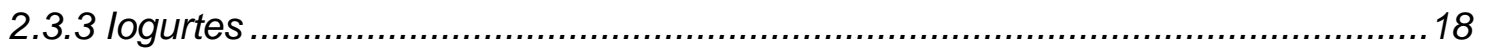

2.3.4 Outros Produtos Lácteos ................................................................20

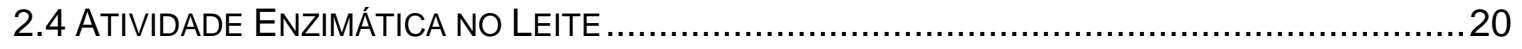

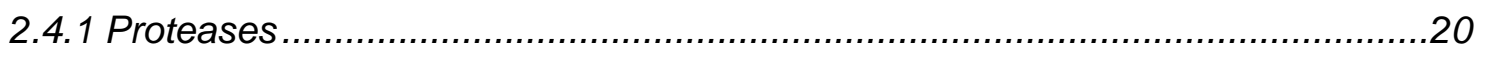

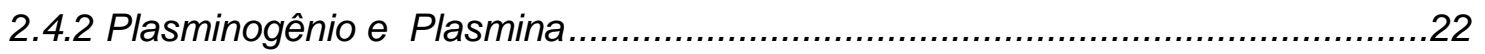

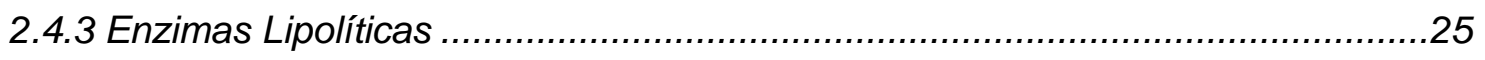

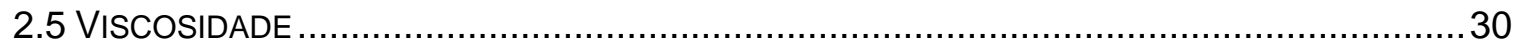

2.6 ASPECTOS DA TECNOLOGIA DE FABRICAÇÃO DE IOGURTES ............................................ 32

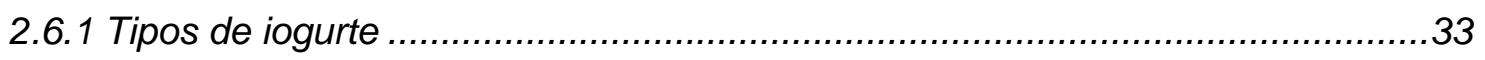

2.6.2 Padronização do Teor de Sólidos Totais ..........................................................33 


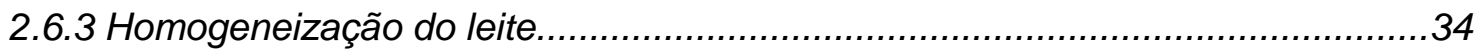

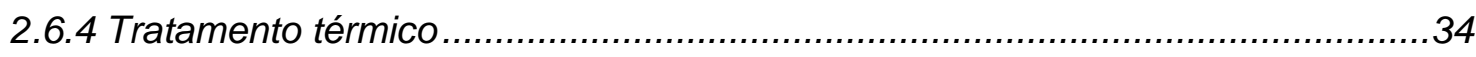

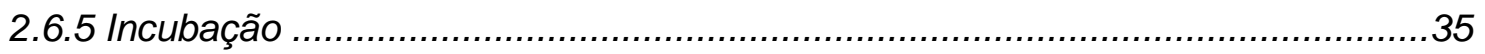

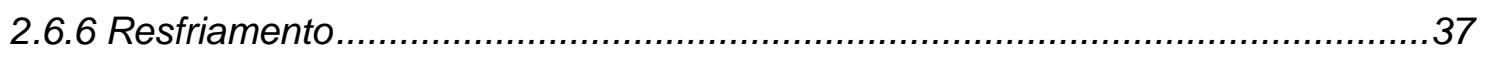

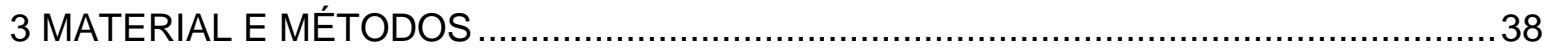

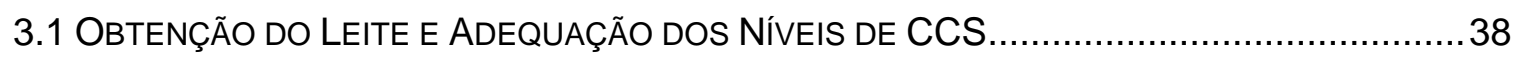

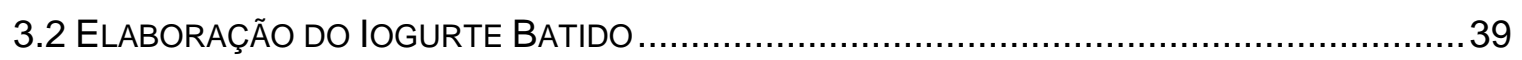

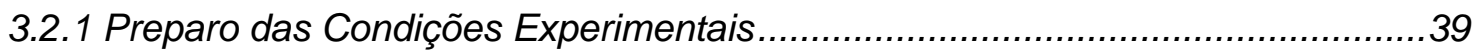

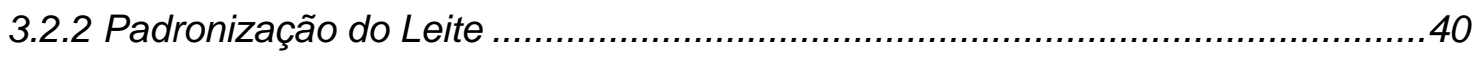

3.2.3 Tratamento Térmico do Leite .................................................................... 40

3.2.4 Semeadura, Incubação e Embalagem ......................................................41

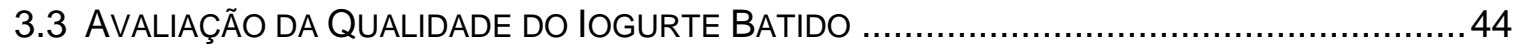

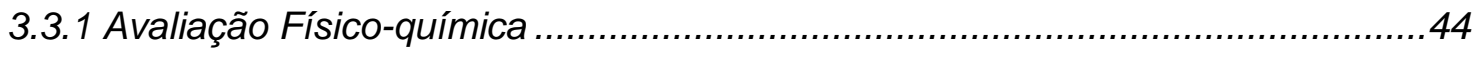

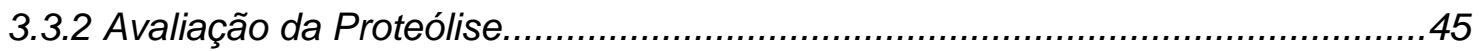

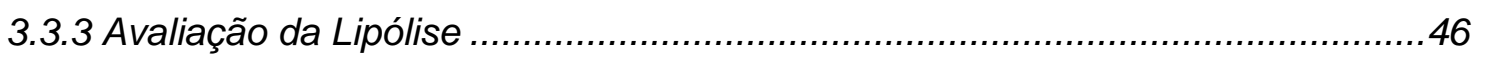

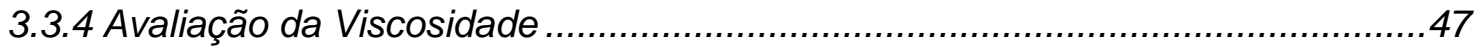

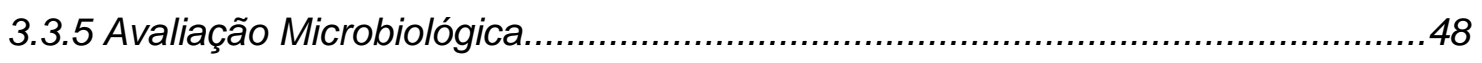

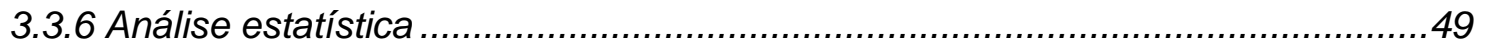

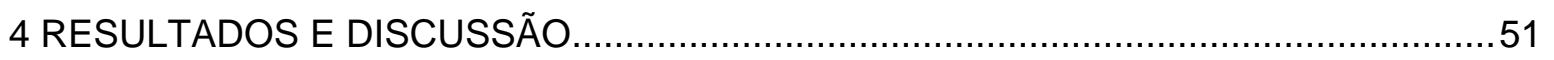

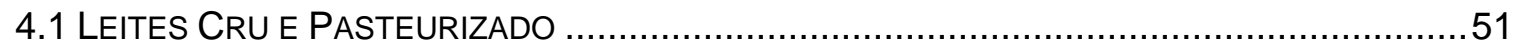

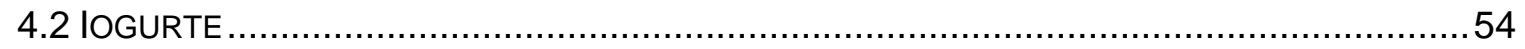

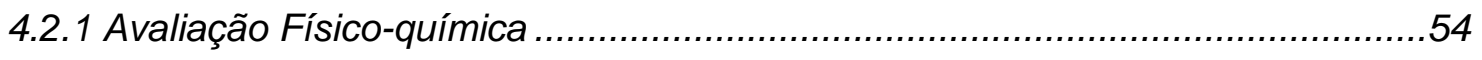

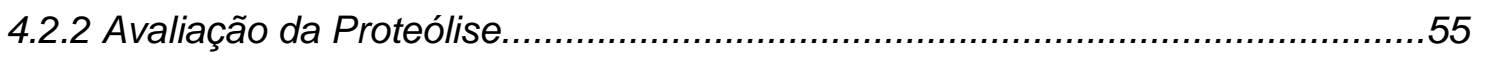

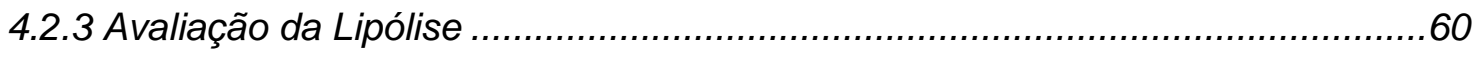

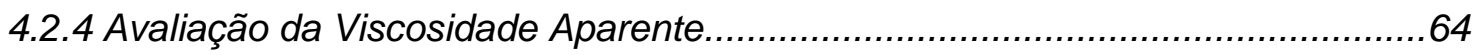

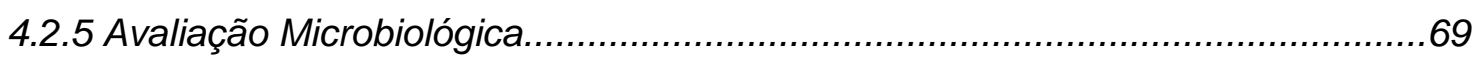

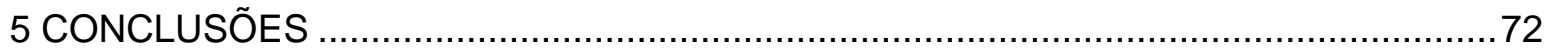

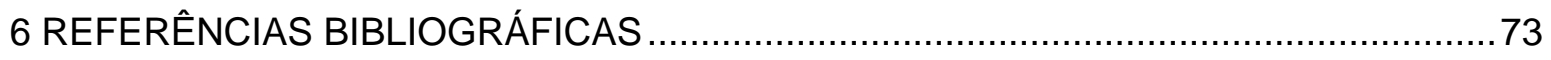




\section{ÍNDICE DE FIGURAS}

FIGURA 1. REPRESENTAÇÃO ESQUEMÁTICA DO SISTEMA DA ENZIMA PLASMINA NO LEITE

(BASTIAN \& BROWN, 1996).

FIgURA 2. ADIÇÃO DE CULTIVO STARTER AO LEITE CONTIDO NA IOGURTEIRA.

FIGURA 3. AGITAÇÃo PARA A QUEBRA DO COÁGULO.

FIGURA 4. DETALHE MOSTRANDO O ENVASE DO IOGURTE.

FIGURA 5. IOGURTES ARMAZENADOS EM CÂMARA FRIA.

FIGURA 6. MENSURAÇÃO DA VISCOSIDADE APARENTE DO IOGURTE. 48

FIGURA 7: FLUXOGRAMA DAS OPERAÇÕES PARA A OBTENÇÃO DO LEITE, PROCESSAMENTO DO IOGURTE, AMOSTRAGEM E RESPECTIVAS ANÁLISES. 50

FIgURA 8. CURVA DE CALIBRAÇÃO CONSTRUÍDA COM O PADRÃO DE ÁCIDO PALMÍTICO,

OBTIDA NA ANÁLISE DE ÁCIDOS GRAXOS LIVRES NOS IOGURTES. .60

FIGURA 9. EVOLUÇÃO DAS CONCENTRAÇÕES DE ÁCIDOS GRAXOS LIVRES (EXPRESSO EM ÁCIDO PALMÍTICO) DOS IOGURTES NOS DIAS 1, 10, 20 E 30 APÓS A FABRICAÇÃO. ...62

FIGURA 10. RELAÇÃO ENTRE A CONTAGEM DE CÉLULAS SOMÁTICAS (LOG CCS) E A CONCENTRAÇÃO DE ÁCIDOS GRAXOS LIVRES (AGL - EXPRESSO EM ÁCIDO PALMÍTICO) NO IOGURTE NO $1^{\circ}$ DIA APÓS A FABRICAÇÃO.

FIGURA 11. RELAÇÃo ENTRE A CONTAGEM DE CÉLULAS SOMÁTICAS (LOG CCS) E A CONCENTRAÇÃO DE ÁCIDOS GRAXOS LIVRES (AGL - EXPRESSO EM ÁCIDO PALMÍTICO) NO IOGURTE NO $30^{\circ}$ DIA APÓS A FABRICAÇÃO. 64

FIGURA 12. CURVA DE VISCOSIDADE APARENTE DOS IOGURTES NO DIA 1 APÓS FABRICAÇÃO. 65

FIGURA 13. CURVA DE VISCOSIDADE APARENTE DOS IOGURTES NO DIA 10 APÓS

FABRICAÇÃO. 65

FIGURA 14. CURVA DE VISCOSIDADE APARENTE DOS IOGURTES NO DIA 20 APÓS FABRICAÇÃO. 66 
FIGURA 15. CURVA DE VISCOSIDADE APARENTE DOS IOGURTES NO DIA 30 APÓS

FABRICAÇÃO. 66

FIGURA 16. EVOLUÇÃO DAS MÉDIAS DE VISCOSIDADE APARENTE DOS IOGURTES NOS DIAS

1, 10, 20 E 30 APÓS A FABRICAÇÃO. 68

FIGURA 17. EVOLUÇÃO DA CONTAGEM DE BACTÉRIAS LÁCTICAS DOS IOGURTES NOS DIAS 1, 10, 20 E 30 A FABRICAÇÃO. .71 


\section{ÍNDICE DE TABELAS}

TABELA 1. CONTAGEM DE CÉLULAS SOMÁTICAS (CCS) NO LEITE UTILIZADO NAS REPETIÇÕES DE LOTES DE IOGURTES.

TABELA 2. VALORES DE DENSIDADE, ACIDEZ, PH E ÍNDICE CRIOSCÓPICO (IC) DO LEITE $\mathrm{CRU}^{1}$, DE ACORDO COM A CONTAGEM DE CÉLULAS SOMÁTICAS (CCS)*

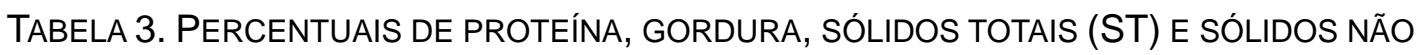
GORDUROSOS (SNG) DO LEITE CRU ${ }^{1}$, DE ACORDO COM A CONTAGEM DE CÉLULAS SOMÁTICAS (CCS).

TABELA 4. VALORES DE MESÓFILOS E PSICROTRÓFICOS DO LEITE CRU ${ }^{1}$, DE ACORDO COM A CONTAGEM DE CÉLULAS SOMÁTICAS (CCS)*.

TABELA 5. VALORES DE MESÓFILOS, PSICROTRÓFICOS E COLIFORMES TOTAIS DO LEITE PASTEURIZADO ${ }^{1}$, DE ACORDO COM A CONTAGEM DE CÉLULAS SOMÁTICAS (CCS) ${ }^{*} .54$

TABELA 6. VALORES DE ACIDEZ, PH, GORDURA, SÓLIDOS TOTAIS (ST) E SÓLIDOS NÃO GORDUROSOS (SNG) DO IOGURTE ${ }^{1}$, DE ACORDO COM A CONTAGEM DE CÉLULAS SOMÁTICAS (CCS)*.....

Tabela 7. Percentuais de proteína total, PRoteína Verdadeira e caseína do IOGURTE ${ }^{1}$, DE ACORDO COM A CONTAGEM DE CÉLULAS SOMÁTICAS (CCS)*...

TABELA 8. VALORES OBTIDOS NO CÁLCULO DO ÍNDICE DE PROTEÓLISE E RELAÇÕES NNC / NT E NNP / NT DO IOGURTE ${ }^{1}$, DE ACORDO COM A CONTAGEM DE CÉLULAS SOMÁTICAS (CCS)*....

TABELA 9. CORRELAÇÃo (R) ENTRE A CONTAGEM DE CÉLULAS SOMÁTICAS (LOG) E O ÍNDICE DE PROTEÓLISE E AS RAZÕES NNC / NT E NNP / NT DO IOGURTE*. 60

TABELA 10. CONCENTRAÇÕES DE ÁCIDOS GRAXOS LIVRES (AGL) DO IOGURTE ${ }^{1}$, DE ACORDO COM A CONTAGEM DE CÉLULAS SOMÁTICAS (CCS).

TABELA 11. CORRELAÇÃo (R) ENTRE A CONTAGEM DE CÉLULAS SOMÁTICAS (LOG) E A CONCENTRAÇÃO DE ÁCIDOS GRAXOS LIVRES DO IOGURTE. 
TABELA 12. VISCOSIDADE APARENTE DO IOGURTE ${ }^{1}$, DE ACORDO COM A CONTAGEM DE CÉLULAS SOMÁTICAS (CCS).

TABELA 13. CoRRELAÇÃo (R) ENTRE A CONTAGEM DE CÉLULAS SOMÁTICAS (LOG) E A VISCOSIDADE APARENTE DO IOGURTE. 68

TABELA 14. CONTAGEM DE BACTÉRIAS LÁCTICAS E COLIFORMES TOTAIS DO IOGURTE ${ }^{1}$, DE ACORDO COM A CONTAGEM DE CÉLULAS SOMÁTICAS (CCS)...... 70 


\section{LISTA DE ABREVIATURAS, SÍMBOLOS E SIGLAS}

\begin{tabular}{|c|c|}
\hline AGL & Ácidos graxos livres \\
\hline C & Caseína \\
\hline${ }^{\circ} \mathrm{C}$ & Graus centígrados \\
\hline $\operatorname{CCS}$ & Contagem de células somáticas \\
\hline CECS & Contagem eletrônica de células somáticas \\
\hline $\mathrm{CHM}$ & Clorofórmio:Heptano:Metanol \\
\hline CMT & California Mastitis Test \\
\hline CS & Células somáticas \\
\hline $\mathrm{cP}$ & Centipoise \\
\hline${ }^{\circ} \mathrm{D}$ & Graus Dornic \\
\hline g & Grama \\
\hline HT-ST & High Temperatute - Short Time \\
\hline IC & Índice crioscópico \\
\hline L & Litro \\
\hline LLP & Lipase lipoproteica \\
\hline $\log$ & Logarítmo \\
\hline meq & Miliequivalente \\
\hline MGGL & Membrana do glóbulo de gordura do leite \\
\hline $\mathrm{Mg}$ & Miligrama \\
\hline $\mathrm{mL}$ & Mililitro \\
\hline MRS & Ágar De Man, Rogosa e Sharpe \\
\hline NMP & Número mais provável \\
\hline NNC & Nitrogênio não caseinoso \\
\hline NNP & Nitrogênio não protéico \\
\hline NT & Nitrogênio total \\
\hline$P$ & Probabilidade \\
\hline PCA & Plate count agar \\
\hline PV & Proteína verdadeira \\
\hline r & Coeficiente de correlação \\
\hline$r^{2}$ & Coeficiente de determinação \\
\hline rpm & Rotações por minuto \\
\hline SNG & Sólidos não gordurosos \\
\hline ST & Sólidos totais \\
\hline
\end{tabular}


$\mathrm{ufc} / \mathrm{mL}$

UHT

$\mu \mathrm{mol}$

WMT
Unidade formadora de colônia por mililitro

Ultra High Temperature

Micromol

Wisconsin Mastitis Test 


\section{RESUMO}

O objetivo do presente estudo foi avaliar as características físico-químicas, microbiológicas, índices de proteólise, lipólise e viscosidade do iogurte natural batido, elaborado a partir de leite integral contendo três níveis de células somáticas (CS): $<400.000$ células $/ \mathrm{mL}, 400.000-800.000$ células $/ \mathrm{mL}$ e $>800.000$ células $/ \mathrm{mL}$. Cada tipo de leite foi obtido da ordenha de animais previamente selecionados de acordo com o nível de CS e a composição do leite. Para a fabricação do iogurte, o leite foi padronizado quanto ao teor de sólidos totais (ST) e transferido para tanque multi-uso, no qual foi submetido à pasteurização $\left(90^{\circ} \mathrm{C}, 15\right.$ minutos), seguida da adição da cultura starter, incubação $\left(42^{\circ} \mathrm{C}\right.$, aprox. 3 horas) e envase do produto. iogurte foi mantido em câmara fria a $5^{\circ} \mathrm{C}$, sendo que os parâmetros de qualidade foram avaliados mediante a colheita de amostras nos dias 1, 10, 20 e 30 após a fabricação. A seqüência de elaboração foi repetida seis vezes, no período de março a agosto/2003. As análises efetuadas no produto incluíram: pH, acidez, percentuais de gordura, ST, sólidos não-gordurosos (SNG), nitrogênios total (NT), não caseinoso (NNC) e não protéico (NNP), ácidos graxos livres (AGL), viscosidade aparente, contagem de bactérias láticas e coliformes a $30^{\circ}$ e $45^{\circ} \mathrm{C}$. Não foram constatadas diferenças $(P>0,05)$ entre os parâmetros físico-químicos e microbiológicos obtidos no leite e no iogurte. Os índices de proteólise dos iogurtes, estimados através da relação NT - NNC / NT - NNP, mantiveram-se constantes, não apresentando diferenças entre os tratamentos $(P>0,05)$. A viscosidade do iogurte produzido com leite contendo mais de 800.000 células $/ \mathrm{mL}$ foi maior $(\mathrm{P}<$ 0,05) em relação aos outros tratamentos nos dias 10, 20 e 30 após a fabricação, observando-se uma correlação positiva $(P<0,05)$ com os níveis de CS no $10^{\circ}$ e $20^{\circ}$ dia de armazenamento. A concentração de $A G L$ foi maior $(P<0,05)$ no iogurte de alta contagem de CS no $1^{\circ}$ e $30^{\circ}$ dia de armazenamento, sendo observada uma correlação positiva $(P<0,05)$ com o nível de CS nos mesmos dias. Os resultados indicam que o aumento dos níveis de CS no leite não apresenta efeitos sobre a proteólise do iogurte, porém origina um aumento na viscosidade e no grau de lipólise do produto durante o armazenamento por 30 dias.

Palavras-chave: Contagem de células somáticas, iogurte, qualidade do leite, proteolise, lipólise, viscosidade. 


\section{ABSTRACT}

The aim of the present study was to evaluate physical, chemical and microbiological characteristics, as well as proteolysis, lipolysis and viscosity of plain stirred yoghurt produced from whole milk with somatic cell counts (SCC) at levels of $<400,000$ cells $/ \mathrm{mL}, 400,000-800,000$ cells $/ \mathrm{mL}$ and $>800,000$ cells $/ \mathrm{mL}$. Each milk treatment was obtained from selected cows, according to its SSC status and milk composition. Yoghurts were produced after standardisation of milk total solids (TS), followed by pasteurisation $\left(90^{\circ} \mathrm{C}, 15\right.$ minutes), addition of starter culture, incubation $\left(42^{\circ} \mathrm{C}\right.$, approx. 3 hours) and packaging. Yoghurts were stored at $5^{\circ} \mathrm{C}$, and quality evaluation was conducted in samples collected on days 1, 10, 20 and 30 after production. Manufacturing procedures were repeated for six times, from March to August/2003. Yoghurt analyses included: $\mathrm{pH}$, acidity, fat, protein, TS, solids non-fat (SNF), total nitrogen (TN), non-casein nitrogen ( $\mathrm{NCN})$ and non-protein nitrogen (NPN), free fatty acids (FFA), apparent viscosity, lactic bacteria counts and coliforms at 30 and $45^{\circ} \mathrm{C}$. There were no differences $(P>0.05)$ in physical, chemical and microbiological parameters of milk and yoghurt among treatments. Proteolysis, as estimated by TN - NCN / TN - NPN relation, was constant for all treatment yoghurts $(P>0.05)$. Viscosity of high SCC yoghurt $(>800,00$ cells $/ \mathrm{mL})$ increased $(P<0.05)$ on 10, 20 and 30 days storage, and a positive correlation $(P<0.05)$ with SCC was observed on days 20 and 30. FFA content was higher $(P<0.05)$ on days 1 and 30 of storage, and besides there was a positive correlation $(P<0.05)$ between SCC and FFA levels on the same days of storage. Results indicate that high SCC milk do not affect proteolysis of yoghurt, although it increases viscosity and lypolisis during storage for 30 days.

Keywords: Somatic cell count, yoghurt, milk quality, proteolysis, lipolysis, viscosity. 


\section{INTRODUÇÃo}

No Brasil, a atividade de produção de iogurtes tem crescido em grandes proporções nos últimos anos, saltando de aproximadamente 60 mil toneladas em 1980 para 470 mil toneladas em 1998. O consumo interno do produto também aumentou, principalmente no período de 1994 a 1997, quando variou de 1,4 para 3,0 kg/habitante/ano (ANUÁRIO MILKBIZZ, 1999). Estes dados justificam a contínua busca do setor industrial por produtos com qualidade e competitividade no mercado. Em 2001 foram vendidas 326 mil toneladas de iogurtes no país. Em 2002, a previsão de comercialização do produto foi de 400 mil toneladas, o que deve ter movimentado o valor de $\mathrm{R} \$ 1,2$ bilhão. O consumo do produto aumentou $89,4 \%$ entre 1994 e 1995, sendo que, no período de 1994 a 1997, o consumo de iogurte foi maior que o de frango (39,9\%), de carne bovina $(27,15 \%)$ e de biscoitos $(42,6 \%)$ (MILKPOINT, 2002).

A mastite é a doença de maiores custos no rebanho leiteiro, sendo que as perdas relativas à enfermidade são duas vezes mais elevadas do que as perdas relacionadas à infertilidade e às doenças reprodutivas. Cada quarto infectado com um patógeno causador de mastite produz aproximadamente $727 \mathrm{~kg}$ a menos de leite por lactação em comparação aos quartos não infectados (PHILPOT \& NICKERSON, 2002). A mastite ocasiona um aumento na liberação de células de diversos tipos no leite, sendo que a gravidade da doença é proporcional à 
contagem de células somáticas (CCS) obtida no produto (BIBALKE, 1984).

Considerando a relação direta entre a ocorrência de mastite e a perda das características do leite, justifica-se a crescente importância da CCS como parâmetro para avaliar a qualidade do leite não processado. Nas últimas décadas, muitos países têm estabelecido limites de referência, cujos valores compreendem: 750.000 células/mL nos Estados Unidos, 400.000 células/mL na União Européia (PHILPOT, 2002) e na Nova Zelândia (LARANJA \& AMARO, 1998), e 500.000 células/mL no Canadá (PHILPOT \& NICKERSON, 2002). Adicionalmente, diversos países têm instituído o sistema de pagamento do leite por qualidade, de acordo com parâmetros composicionais, físico-químicos e de higiene. A contagem de células somáticas (CCS) pode também vir a ser um critério de pagamento por qualidade, a exemplo do que já ocorre em alguns locais dos EUA.

A legislação brasileira contemplava apenas as características físicoquímicas do leite, como acidez, teores de gordura e extrato seco, densidade e índice crioscópico, além da contagem global de microrganismos mesófilos (MINISTÉRIO DA AGRICULTURA, 1980). Recentemente, o Ministério da Agricultura, Pecuária e Abastecimento reformulou, através da Instrução Normativa $N^{\circ} 51$, de 18 de setembro de 2002, os itens utilizados para a avaliação da qualidade do leite, incluindo, pela primeira vez no Brasil, a CCS como um dos critérios para aceitação do leite. Esta norma estabeleceu que o limite máximo legal fixado a partir de 2005 é de 1.000 .000 células/mL, nas regiões Sul, Sudeste e Centro-Oeste, e a partir de 2007 para as regiões Norte e Nordeste (MINISTÉRIO DA AGRICULTURA, 2003). Desta forma, é de fundamental importância o estudo do impacto da CCS sobre a qualidade do leite e derivados, uma vez que a adoção de novos critérios para avaliação da qualidade do leite deve ser embasada em resultados de pesquisa que subsidiem as utilidades destes parâmetros. 
Com base nos aspectos mencionados, e considerando que existem poucos dados disponíveis na literatura sobre os efeitos da contagem de células somáticas sobre a qualidade do iogurte, constituíram objetivos do presente trabalho:

a) Determinar as características fisico-químicas, microbiológicas, índices de proteólise, lipólise e viscosidade do iogurte natural batido, produzido a partir de leite integral contendo três níveis de CCS $(<400.000$ células $/ \mathrm{mL}, 400.000$ 800.000 células $/ \mathrm{mL}$ e >800.000 células $/ \mathrm{mL}$ );

b) Avaliar as possíveis diferenças entre os parâmetros do iogurte produzido com os três tipos de leite durante o armazenamento por 30 dias. 


\section{REVISÃO DA LITERATURA}

\subsection{Mastite e Células Somáticas}

A mastite é definida como uma inflamação da glândula mamária, de origem predominantemente bacteriana (INTERNATIONAL DAIRY FEDERATION, 1987). Em processos infecciosos do tecido glandular, observa-se freqüentemente um aumento na liberação de células de diversos tipos no leite, as quais podem ser enumeradas no produto através de técnicas de contagem de células somáticas (LARANJA \& AMARO, 1998).

A CCS tem sido utilizada em países desenvolvidos há mais de 25 anos, quando se tornou uma prática acessível aos produtores pelo advento de equipamentos eletrônicos (FONSECA \& SANTOS, 2000). Inicialmente utilizada apenas para diagnóstico de mastite subclínica (LARANJA \& AMARO, 1998), atualmente tem também importância na estimativa de perdas na produção e como indicativo da qualidade do leite (FONSECA \& SANTOS, 2000).

As células somáticas (CS) estão presentes normalmente no leite e são constituídas, em sua grande maioria, por leucócitos, sobretudo neutrófilos, e células de descamação do epitélio secretor da glândula (BIBALKE, 1984; NICKERSON, 1994). Em um quarto infectado, aproximadamente $99 \%$ de todas as células do leite são leucócitos, enquanto que o percentual remanescente é formado por células epiteliais secretoras do tecido mamário. A distribuição das células em uma glândula 
sadia é de $60 \%$ de macrófagos, $25 \%$ de linfócitos e 15\% de neutrófilos (PHILPOT \& NICKERSON, 2002). Durante a evolução da mastite há um influxo maior dessas células para a glândula mamária, conduzindo à elevação do seu número no leite (BIBALKE, 1984; NICKERSON, 1994).

A CCS é um fenômeno dinâmico, estando sujeita a variações significativas. O estágio de lactação, a idade da vaca, a estação do ano, o tamanho do rebanho, o nível de produção de leite e a presença de outras doenças são fatores que podem afetar a concentração de células somáticas no leite. Porém, o fator que exerce maior influência sobre o nível de CS do leite é a infecção intramamária. As vacas com mastite subclínica contribuem com um número substancial de CS no leite do rebanho (PHILPOT e NICKERSON, 2002).

A ocorrência de células somáticas no leite pode ser estimada indiretamente através de métodos qualitativos, como o California Mastitis Test (CMT) ou o Wisconsin Mastitis Test (WMT). Contudo, a CCS é realizada, geralmente, através de técnicas diretas, como a microscopia óptica e a contagem em equipamentos eletrônicos (AMERICAN PUBLIC HEALTH ASSOCIATION, 1992). A contagem eletrônica de células somáticas (CECS) é atualmente o método mais moderno e preciso de avaliação da saúde da glândula mamária de vacas individuais e do rebanho (FONSECA \& SANTOS, 2000).

\subsection{CCS e Composição do Leite}

A mastite é uma doença extremamente complexa que resulta em uma redução na quantidade de leite sintetizado e em mudanças nos níveis de componentes específicos do leite, reduzindo sua qualidade (POLITIS \& NG-KWAIHANG, 1988a). A mastite determina consideráveis prejuízos à indústria de laticínios, relacionados às alterações que provoca na composição do leite, reduzindo os 
teores de cálcio, lactose, caseína e gordura, além de aumentar os níveis de íons sódio, cloro e de proteínas séricas (KITCHEN, 1981; OLIVEIRA et al., 1999). As alterações de composição do leite ocorrem em conseqüência à inflamação, que causa diminuição na capacidade de síntese da glândula mamária e aumento da permeabilidade vascular (KITCHEN, 1981; SHUSTER et al., 1991; OLIVEIRA et al., 1999).

\subsubsection{Proteínas}

A fração nitrogenada do leite é constituída pela caseína, pelas proteínas do soro e pelos compostos nitrogenados não protéicos (TAMIME \& ROBINSON, 1991). As proteínas do leite pertencem a duas principais categorias, as quais podem ser separadas baseando-se na solubilidade em pH 4,6 a $20^{\circ} \mathrm{C}$. Sob estas condições, o grupo das caseínas precipita, e as proteínas que permanecem solúveis são denominas séricas. Aproximadamente $80 \%$ do nitrogênio total do leite de bovinos é constituído por caseína. A caseína bovina pode ser classificada em quatro tipos de proteína com diferentes propriedades: $\alpha_{s 1^{-}}, \alpha_{s 2^{-}}, \beta-$, e $\kappa^{-}$, perfazendo, respectivamente, 38\%, 10\%, 34\% e 15\% da caseína total (FOX et al., 2000).

A fração de proteína sérica do leite de bovinos contém quatro principais proteínas: $\beta$-lactoglobulina (50\%), $\alpha$-lactalbumina (20\%), soroalbumina (10\%) e imunoglobulinas (10\%), como $\lg _{1}$ (principalmente), $\lg _{2}$, $\lg A$ e $\lg M$ (FOX et al., 2000). As temperaturas de desnaturação das proteínas séricas são $78^{\circ} \mathrm{C}, 62^{\circ} \mathrm{C}$ e $64^{\circ} \mathrm{C}$ para a $\beta$-lactoglobulina, $\alpha$-lactoalbumina e soroalbumina respectivamente. As imunoglobulinas são muito termolábeis (BROWN, 1988).

Os resultados experimentais são conflitantes no que se refere aos efeitos de elevadas CCS no leite sobre a concentração de proteína total do leite medida pela concentração de nitrogênio total. Diversos autores relataram que o leite de vacas 
com alta CCS apresenta maiores níveis de proteína total, quando comparado ao de vacas sadias (MILLER et al, 1983; AULDIST et al, 1995; KLEl et al., 1998; URECH et al., 1998; MARQUES et al., 2002; SOMERS et al., 2003). WEAVER e KROGER (1976) afirmam que a proteína total do leite aumenta com a CCS, assim como as proteínas séricas. KLEl et al. (1998) reportaram que um aumento na CCS de 83.000 para 872.500 células $/ \mathrm{mL}$ influencia a composição do leite. Assim, o leite com alta CCS apresenta maiores valores de proteína, porém menores teores de caseína como porcentagem da proteína verdadeira.

De forma contrária, HAENLEIN et al. (1973), MITCHELL et al. (1986) e VERDI et al. (1987) não identificaram diferenças entre os teores de proteína total de vacas com altas CCS e vacas sadias. ROGERS et al. (1989a) relataram redução no teor de proteína total no leite de vacas com elevada CCS.

Segundo SCHULTZ (1977), os efeitos das mastites sobre a proteína do leite são de natureza qualitativa, uma vez que os valores absolutos de proteína bruta não sofrem alterações significativas. Assim, o leite proveniente de vacas com mastite apresenta menor teor de caseína, que é a proteína nobre do leite, porém há aumento dos níveis de proteínas séricas, como soroalbuminas e imunoglobulinas. BALLOU et al. (1995) observaram que a porcentagem de caseína foi significativamente maior quando o leite era proveniente de um grupo de vacas que apresentava baixa CCS em relação a grupos de maiores contagens.

De acordo com HAENLEIN et al. (1973), exceto para proteína total, todas as outras concentrações mudam com o aumento da contagem de leucócitos no leite. Amostras de leite com maiores contagens apresentam menores valores para caseína total, menor relação caseína:proteína total e maiores quantidades de proteínas do soro do que amostras com baixas contagens. Adicionalmente, ocorre um decréscimo nas quantidades de $\alpha_{s 1}$-caseína, $\beta$-caseína, $\beta$-lactoglobulina e $\alpha$ - 
lactalbumina, enquanto que as quantidades de imunoglobulinas, soroalbuminas e $\kappa$ caseína aumentam (HAENLEIN et al., 1973). O decréscimo da $\beta$-caseína é mais pronunciado que o da $\alpha_{s 1}$-caseína (ANDERSON \& ANDREWS, 1977; ANDREWS, 1983).

As alterações na caseína compreendem também o balanço entre caseína micelar e solúvel, encontrando-se no leite com alta CCS maior concentração de caseína solúvel e menor de caseína micelar (SHARMA \& RANDOLPH, 1974). No leite normal, cerca de $95 \%$ do total de caseína é encontrada em micelas, enquanto que no leite de vacas com mastite clínica há apenas 46\% (SINGH \& GANGULI, 1975).

ANDERSON \& ANDREWS (1977) afirmaram que no leite com alta CCS as concentrações de soroalbumina e imunoglobulinas aumentam acentuadamente, concordando com RANDOLPH et al. (1974), os quais reportaram que no leite considerado positivo no WMT foram encontradas concentrações $68 \%$ maiores de soroalbumina, cinco vezes mais imunoglobulinas, maiores teores de $\alpha_{s^{-}}$e $\kappa$ caseínas, e menores concentrações de $\beta$-lactoglobulina e $\beta$-caseína, 25\% e 22\%, respectivamente, em comparação ao leite negativo.

De acordo com CAFFIN et al. (1985), há uma correlação negativa entre a concentração de $\alpha$-lactalbumina e a CCS $(r=-0,31)$, a qual é amplificada pelo status de infecção dos quartos. Nenhuma correlação foi notada entre a CCS e a concentração de $\beta$-lactoglobulina quando considerado um período completo de amostragem, porém a correlação tornou-se negativa nos quartos infectados pelos patógenos de maior importância, como o Staphylococcus aureus e estreptococos.

A CCS foi correlacionada $(r=0,53)$ às concentrações de soroalbumina no leite. Cerca de $32 \%$ dos quartos infectados pelos patógenos de maior importância apresentam menos de 500.000 células $/ \mathrm{mL}$, enquanto que em $47,5 \%$ deles pode-se 
observar teores de soroalbumina inferiores a $0,2 \mathrm{mg} / \mathrm{mL}$. Para infecções subclínicas, as concentrações de soroalbumina aumentaram pronunciadamente quando a CCS foi maior que 1.000 .000 células/mL (POUTREL et al., 1983).

A alta CCS, segundo POLITIS \& NG-KWAI-HANG (1988b), tem profundo efeito nas propriedades de coagulação do leite, uma vez que estas são intimamente relacionadas à composição do mesmo. As conseqüências mais importantes das alterações na proteína manifestam-se sobre o rendimento industrial e o valor nutritivo dos produtos lácteos, sobretudo queijos e iogurtes.

\subsubsection{Lactose}

A lactose, principal carboidrato no leite, é essencial para a produção de derivados lácteos fermentados. A concentração de lactose no leite sofre variações de acordo com a raça da vaca, fatores individuais, infecção no úbere e estágio de lactação. A lactose e os íons solúveis $\left(\mathrm{Na}^{+}, \mathrm{K}^{+}\right.$e $\left.\mathrm{Cl}^{-}\right)$são os principais componentes responsáveis pela pressão osmótica do leite (FOX et al., 2000).

Durante a mastite, a concentração de $\mathrm{NaCl}$ no leite aumenta, resultando em aumento da pressão osmótica. Este aumento é compensado por meio de uma redução no teor de lactose, havendo uma relação inversa entre a concentração de $\mathrm{NaCl}$ e lactose no leite (FOX et al., 2000). Outros autores concordam que há uma diminuição na concentração de lactose quando se trata de leite de vacas com alta CCS (MILLER et al., 1983; ROGERS et al., 1989a; AULDIST et al., 1995; SOMERS et al, 2003; FERNANDES et al., 2003).

KLEl et al. (1980) reportaram que um aumento de 83.000 células/mL para 870.000 células/mL no leite corresponde a uma diminuição na concentração de lactose de 4,98\% para 4,71\%. MILLER et al. (1983) observaram uma correlação negativa entre a porcentagem de lactose no leite e a severidade da mastite, e esta 
determina uma redução contínua na concentração de lactose no leite com CCS acima de 100.000 células $/ \mathrm{mL}$. O decréscimo na concentração de lactose, segundo MARQUES et al. (2002), pode ser notado a partir de 300.000 células $/ \mathrm{mL}$, e pode ser explicado pela diminuição da capacidade de síntese da glândula, além da possível passagem de lactose do leite para o sangue em vacas com mastite (SHUSTER et al., 1991; MARQUES et al., 2002).

\subsubsection{Gordura}

Os teores de gordura no leite podem sofrer variações relacionadas à raça, a fatores individuais, estágio de lactação, idade, saúde do animal, status nutricional e intervalo entre as ordenhas. Os lipídeos no leite são predominantemente triglicerídeos, os quais perfazem aproximadamente $98 \%$ do total da fração lipídica, enquanto que os $2 \%$ restantes compreendem diglicerídeos, monoglicerídeos, ácidos graxos, fosfolipídeos, esteróis (principalmente colesteróis) e traços de vitaminas lipossolúveis.

Os glóbulos de gordura, que possuem em média de 3 a $4 \mu \mathrm{m}$ de diâmetro (FOX et al., 2000), são envolvidos por uma fina camada (LEE \& SHERBON, 2002) denominada membrana do glóbulo de gordura do leite (MGGL). A MGGL consiste em uma complexa mistura de proteínas, glicoproteínas, triglicerídeos, fosfolipídeos, colesterol, enzimas e outros compostos minoritários. A principal enzima endógena que compõem a MGGL é a xantina oxidase (FOX et al., 2000).

EL-DEEB e HASSAN (1987) reportaram menores teores de gordura no leite de vacas com mastite. De fato, pode-se observar no leite com alta CCS menor concentração de gordura devido ao fato de haver menor síntese de gordura pela glândula mamária (RANDOLPH \& ERWIN, 1974; SCHULTZ, 1977). Entretanto, alguns autores sugerem que a correlação entre a CCS e o percentual de gordura 
pode ser negativa, positiva ou nula, dependendo do valor médio da CCS no leite dos rebanhos (SCHULTZ, 1977; MUNRO et al., 1984). MARQUES et al. (2002) observaram maiores concentrações de gordura de acordo com a elevação dos níveis de CCS.

\subsubsection{Minerais}

As concentrações dos minerais durante a mastite são também alteradas, afetando significativamente a qualidade do leite (AUDIST \& HUBBLE, 1998) e influenciando as características do mesmo para o processamento (MUNRO et al., 1984). O cálcio no leite pode ser encontrado na forma ionizada, ligado às micelas de caseína ou associado ao citrato e fosfato. Durante a mastite, há redução na concentração de cálcio no leite (NEVILLE \& WATTERS, 1983).

TALLAMY e RANDOLPH (1970) reportaram que no leite positivo para o WMT foram encontradas 9\%, 8\% e 4\% menores concentrações de potássio, fósforo inorgânico e cálcio, respectivamente, em relação às amostras de leite negativas. Adicionalmente, as amostras WMT positivas apresentaram aumento de cerca de $38 \%$ nos níveis de sódio, $22 \%$ de cobre, $19 \%$ de ferro, $8 \%$ de zinco e $6 \%$ de magnésio. Em um nível de 250.000 células $/ \mathrm{mL}$, ocorre um significativo aumento nos teores de sódio e na relação sódio:potássio. A alta CCS pode também ocasionar aumento na concentração de cloro e na relação cloro:lactose (ROGERS et al., 1989b).

\subsubsection{Sólidos Totais}

KLEl et al. (1980) e MARQUES et al. (2002) relataram que os sólidos totais não são influenciados pelo aumento da CCS. No entanto, FERNANDES et al. 
(2003) observaram uma correlação negativa entre a CCS e a concentração de sólidos totais quando o nível de CCS supera 1.000 .000 de células/mL.

Significativos decréscimos no teor de sólidos não gordurosos foram observados quando o valor de CCS atingiu 500.000 células/mL (ROGERS et al., 1989a).

\subsubsection{Alterações microbiológicas}

A ocorrência de mastite pode afetar, também, a qualidade microbiológica do leite. Primeiramente, os próprios patógenos causadores da mastite podem gerar aumento na contagem global em placa de microrganismos do leite entregue à indústria. Isto é particularmente importante em rebanhos que apresentam alta prevalência da doença causada por Streptococcus agalactiae e S. uberis. Além disso, outras bactérias causadoras de mastite, tais como Staphylococcus aureus e Escherichia coli, podem gerar toxinas termorresistentes, o que representa um risco considerável à saúde humana (BRAMLEY, 1996).

Os valores de CCS estão diretamente relacionados ao aumento na contagem de bactérias psicrotróficas no leite. Esta associação advém do fato de que a principal fonte destes microrganismos é a superfície externa dos tetos (PACKARD \& GINN, 1991). Assim, quanto melhor a desinfecção dos tetos, mais baixa a CCS e menor a concentração de bactérias psicrotróficas no leite produzido. Deve-se ressaltar que os critérios de higiene da glândula mamária tornam-se ainda mais importantes à medida que se intensificam as ações para o resfriamento do leite na propriedade rural, imediatamente após a ordenha, a exemplo do que vem ocorrendo atualmente no país.

O tratamento das mastites apresenta sérias implicações em Saúde Pública, pela presença de resíduos de antibióticos no leite. Alguns estudos têm demonstrado 
que a maior fonte destes resíduos é representada pela freqüente inoculação intramamária de antibióticos utilizados no combate à mastite (ALLISON, 1995).

\subsection{CCS e Qualidade dos Produtos Lácteos}

Em conseqüência às alterações na composição do leite, diversos efeitos podem ser observados na produção de derivados lácteos, entre os quais destacamse: menor rendimento industrial; diminuição do valor nutritivo dos alimentos lácteos; redução do tempo de prateleira, devido à ação de enzimas que contribuem para conferir sabores estranhos ao alimento; e, em certos casos de mastite, menor qualidade microbiológica do produto final, resultante do aumento da contagem global de microrganismos (KITCHEN, 1981; OLIVEIRA et al., 1999).

\subsubsection{Leites Pasteurizado e Ultra-High Temperature (UHT)}

Em estudo sobre o leite pasteurizado, MA et al. (2000) constataram que a qualidade organoléptica do leite com baixa CCS permaneceu alta mesmo após 21 dias de armazenamento, enquanto que para o leite com altos níveis de células somáticas, houve defeitos sensoriais significativos perceptíveis após os 21 dias. O decréscimo na qualidade sensorial observado entre 14 e 21 dias de armazenamento foi provavelmente causado por altos níveis de enzimas lipolíticas e proteolíticas. De fato, o leite pasteurizado com alta CCS foi mais suscetível à lipólise durante o armazenamento sob refrigeração.

SANTOS et al. (2003a) afirmaram que a combinação de baixas CCS, baixas temperaturas de armazenamento e baixas contagens bacterianas iniciais pode resultar em um leite fluido que manterá a qualidade sensorial por mais de 61 dias de armazenamento a temperaturas inferiores a $6^{\circ} \mathrm{C}$. 
AULDIST et al. (1996) relacionaram a CCS e o estágio de lactação com a qualidade do leite UHT. Os leites contendo altos níveis de CS (687.000 e 1.463 .000 células/mL para, respectivamente, estágios inicial e avançado de lactação) apresentam menor relação caseína:proteína total, além de maior pH e nível de proteólise quando proveniente de estágio avançado de lactação. Os leites com altas contagens também apresentam tendência de geleificar antes que o de baixas contagens. Segundo MACHADO et al. (1998), o leite UHT com altas contagens apresenta aumento da geleificação e conseqüente diminuição do tempo de prateleira.

\subsubsection{Queijos}

Os níveis de CCS no leite são negativamente relacionados aos teores de gordura, proteína e sólidos totais do queijo (POLITIS \& NG-KWAI-HANG, 1988a), produto lácteo mais estudado. Alterações na composição podem ser observadas, segundo BARBANO et al. (1991), havendo redução da caseína como porcentagem da proteína verdadeira e aumento nas perdas de proteína e gordura no soro. Ocorrem, ainda, alterações negativas nas propriedades organolépticas (MUNRO et al., 1984).

O queijo é também afetado pelas altas contagens no que se refere ao rendimento (GRANDISON \& FORD, 1986), com redução que pode chegar a 5\% (MACHADO et al., 1998), além de aumento no tempo de coagulação (MACHADO et al., 1998; POLITIS \& NG-KWAI-HANG, 1988a). Isto significa uma perda final de 500 $\mathrm{kg}$ de queijo para cada 100.000 litros de leite processado, se for considerado o rendimento médio de $1 \mathrm{~kg}$ de queijo para cada 10 litros de leite utilizado.

Com relação ao coágulo, ocorre diminuição da firmeza, aumento de água e baixa taxa de enrijecimento (POLITIS \& NG-KWAI-HANG, 1988a). De acordo com 
AULDIST \& HUBBLE (1998), modificações no rendimento, tempo de coagulação e firmeza do coágulo são decorrentes das alterações na composição protéica do leite, balanço mineral e perda de sólidos no soro.

O queijo tipo Cheddar elaborado com leite contendo mais de 500.000 células $/ \mathrm{mL}$ apresenta maior umidade e proteólise. O flavor, o corpo e a textura são também afetados (ROGERS \& MITCHELL, 1994), além do tempo de coagulação, firmeza do coágulo e da atividade da cultura starter (KITCHEN, 1981). O tempo de coagulação pode diminuir até $25 \%$ e há maior perda gordura e proteína no soro, resultando em menor rendimento (ROGERS \& MITCHELL, 1994).

Para o queijo tipo Cottage, nota-se também rendimento industrial significativamente menor quando elaborados com leite com alta CCS, além de maior umidade no coágulo e maior proteólise (KLEl et al., 1998). Segundo COONEY et al. (2000), durante o processamento de queijos tipo suíço, como o Emmental, o Gruyere e o Comte, a atividade das proteinases endógenas do leite é claramente aumentada com a elevação da CCS, além de se observar decréscimo na quantidade de proteína total, maior perda de proteína no soro e aumento nos teores de gordura.

\subsection{3 logurtes}

Com relação ao iogurte, são poucos os dados correlacionando a contagem de células somáticas e a qualidade deste produto. ROGERS \& MITCHELL (1994) estudaram a relação entre os níveis de CCS e algumas características do iogurte desnatado. Neste experimento os autores utilizaram misturas de leite com altas e baixas contagens, obtido em duas propriedades leiteiras. Foram avaliados sólidos totais, gordura e pH, além das características organolépticas. Contudo, os resultados obtidos foram conflitantes, visto que a qualidade organoléptica do iogurte 
foi afetada significativamente somente com o leite de uma das propriedades, para níveis acima de 250.000 células $/ \mathrm{mL}$.

OLIVEIRA et al. (2002) realizaram estudo sobre a qualidade do iogurte natural batido produzido com leite contendo diferentes níveis de CCS, constatando decréscimo da qualidade sensorial do produto elaborado com CS acima de 800.000/mL, sobretudo para os atributos consistência, sabor e média geral de aceitação do produto. As médias foram significativas a partir do $10^{\circ}$ dia após a fabricação, com relação à consistência do produto, acentuando-se progressivamente as diferenças ao longo do período de armazenamento, até o $30^{\circ}$ dia. Os parâmetros físico-químicos estudados (acidez, pH, proteína, gordura, ST e SNG) não sofreram variações significativas associadas aos diferentes níveis de CCS utilizados no estudo, porém deve-se ressaltar que a proteína foi analisada como nitrogênio total, não individualizando os teores de caseína e proteínas do soro.

A qualidade do iogurte é diretamente afetada pela qualidade do leite utilizado em sua fabricação (FIGUEIREDO \& PORTO, 2002). As mudanças na composição do leite podem influenciar o crescimento e o metabolismo dos organismos da cultura starter, afetando a coagulação e a textura, flavour, aroma e a qualidade do produto final. A elevada CCS resulta em estimulação do Streptococcus thermophilus, provocando aumento na proteólise, e inibição do Lactobacillus acidophilus, quando ambos são utilizados conjuntamente. No entanto, a adição de starter contendo S. thermophilus e L. bulgaricus, que é tradicionalmente utilizada para a fabricação de iogurte, não demonstrou diferenças consistentes (OKELLOUMA \& MARSHALL, 1986). 


\subsubsection{Outros Produtos Lácteos}

Com relação a outros produtos lácteos, diversos autores têm reportado que os altos níveis de CCS interferem com a qualidade e a produção dos derivados. Há inibição do crescimento do Lactobacillus acidophilus em leites fermentados produzidos com leite contendo altos níveis de células somáticas (MACHADO et al., 1998) e diminuição no tempo de prateleira de manteigas e leites em pó devido à ação de enzimas que deterioram a gordura (FONSECA \& SANTOS, 2000).

\subsection{Atividade Enzimática no Leite}

As alterações no tempo de prateleira ocorrem no leite fluido e em produtos derivados. Este fenômeno deve-se, principalmente, à ação de enzimas proteolíticas, as quais em grande parte são termoestáveis, permanecendo ativas mesmo após os processos usuais de pasteurização do leite. Os principais efeitos destas enzimas manifestam-se na forma de alterações no sabor dos produtos lácteos. As enzimas proteolíticas geram um sabor amargo no leite armazenado e seus derivados, enquanto que as enzimas lipolíticas predispõem à ocorrência de sabor rançoso, em função da quebra dos ácidos graxos de cadeia longa em ácidos graxos de cadeia curta (RANDOLPH \& ERWIN, 1974; MURPHY et al., 1989; RENEAU \& PACKARD, 1991).

Existem no leite, 50 diferentes tipos de atividade enzimática. No entanto, as enzimas nativas com atividade relevante são a lipase lipoproteica (LLP), a plasmina e a lactoperoxidase (MUIR, 1996).

\subsubsection{Proteases}

O aumento da CCS associado à deterioração na qualidade da proteína (GRANDISON \& FORD, 1986) ocorre devido ao fato de, no leite mastítico, ocorrer 
aumento na atividade proteolítica em conseqüência à presença de altos níveis de proteases, que podem ter origem na plasmina (Enzyme Commission - 3.4.21.7), nas células somáticas (DE RHAM \& ANDREWS, 1982; ANDREWS, 1983; VERDI et al., 1987; SAEMAN et al., 1988) ou nas bactérias (GRIEVE \& KITCHEN, 1985).

A atividade proteolítica pode estar associada em grande parte à CCS (SENYK et al., 1985; VERDI et al., 1987; SAEMAN et al., 1988; BALLOU et al., 1995), o que predispõe o leite a uma substancial hidrólise da $\alpha_{S^{-}}$e $\beta$-caseína por proteases, havendo diminuição nos níveis destas frações no leite (RANDOLPH et al., 1974; ANDERSON \& ANDREWS, 1977; DE RHAM \& ANDREWS, 1982; ANDREWS, 1983; VERDI et al., 1987).

A taxa de proteólise das caseínas pelas proteases de diferentes fontes ocorre de acordo com a seguinte predominância: $\alpha_{S 1^{-}}>\beta \beta^{-}>$-caseína para proteases originárias de leucócitos, $\beta$ - $>\alpha_{\mathrm{S}^{-}}{ }^{-}>$ -caseína para a plasmina (GRIEVE \& KITCHEN, 1985), e $\beta^{-} \approx \kappa^{-}>\alpha_{S_{1}}$-caseína para proteases de origem de microrganismos psicrotróficos (GRIEVE \& KITCHEN, 1985; GASSEM \& FRANK, 1991).

Segundo KORYCKA-DAHL et al. (1983), a qualidade do leite e dos produtos lácteos pode ser influenciada por enzimas proteolíticas, como a plasmina. GASSEM e FRANK (1990), em estudo sobre o efeito da degradação da proteína do leite nas propriedades físico-químicas do iogurte, concluíram que proteases microbianas e a atividade da plasmina podem afetar a qualidade do produto.

As proteases provenientes de contaminações com bactérias psicrotróficas, porém, parecem não causar problemas até que seja alcançado um nível de, no mínimo, $10^{7}$ unidades formadoras de colônias (ufc) $/ \mathrm{mL}$. No leite de boa qualidade microbiológica o sistema plaminogênio-plasmina detém o maior potencial para causar quebra de proteínas (GRIEVE \& KITCHEN, 1985). 
A proteólise pode também estar associada à atividade de macrófagos nas células isoladas do leite com alta CCS (VERDI \& BARBANO, 1991a). A atividade proteolítica associada às células somáticas isoladas do leite bovino é de $27,5 \%$ em pH 6,6 (VERDI \& BARBANO, 1991a). A proteólise no produto refrigerado por 72 horas a $6,7^{\circ} \mathrm{C}$ é 1,5 vezes maior em leites com mais de 1.000 .000 de células $/ \mathrm{mL}$ do que em leites com menos de 60.000 células $/ \mathrm{mL}$. A proteólise aumenta com o aumento da CCS, sendo que as proteases associadas com elevada CCS prejudicam a qualidade do leite cru durante o armazenamento, e também de queijos e de leite pasteurizado ao longo da vida de prateleira (SENYK et al., 1985). Ressalta-se que a proteólise pode se iniciar em baixas contagens, a partir de 250.000 células/mL (LE ROUX et al., 1995).

Existe uma intensa atividade proteolítica associada à alta CCS, fato que pode originar uma quantidade significativa de caseína enzimaticamente degradada. As porcentagens de proteína verdadeira, caseína e nitrogênio não protéico no leite sofrem variações sazonais, mas não são afetadas pelo nível de CCS. Porém, a caseína expressa como porcentagem da proteína verdadeira não varia sazonalmente, mas é menor no leite com alta CCS (VERDI et al., 1987).

\subsubsection{Plasminogênio e Plasmina}

A principal atividade proteolítica endógena no leite é decorrente da ação da plasmina, enzima que normalmente se encontra associada à fração de caseína (RICHARDSON, 1983). A proteólise de origem da plasmina perfaz aproximadamente $90 \%$ da proteólise total (BARRY \& DONNELLY, 1981). Os coeficientes de correlação entre a plasmina e a $\alpha_{S}$-caseína, e entre a plasmina e a $\beta$-caseína, descritos por POLITIS et al. (1989), foram de -0,14 e -0,27, respectivamente. 
A ação da plasmina degrada a $\beta-, \alpha_{S 1}$ e a $\alpha_{S 2}$-caseína, sendo que esta atividade aumenta com a severidade da mastite. A regulação da hidrólise da caseína é crítica para a fabricação de produtos lácteos. Quando a caseína é degradada nos produtos fluidos ou antes da coagulação nos derivados lácteos que formam gel, geralmente a qualidade do produto é afetada (BASTIAN \& BROWN, 1996). A plasmina do leite é idêntica à plasmina do sangue, diferindo apenas no peso molecular (MUIR, 1996).

O plasminogênio, que também está presente no leite, pode ser prontamente ativado por ativadores de plasminogênio (RICHARDSON, 1983). Segundo VERDI \& BARBANO (1991b), qualquer fator que converta plasminogênio em plasmina, resultando em proteólise da caseína, pode ter impacto negativo na funcionalidade da proteína do leite e, visto que constituintes das células somáticas são capazes de realizar esta conversão, conclui-se que a fonte de ativação de plasminogênio no leite são as células somáticas. Isto se confirma pelo fato de os leucócitos do sangue bovino e as enzimas bacterianas extracelulares não serem capazes de converter o plaminogênio em plasmina.

No leite normal, pode-se observar uma taxa de ativação do plasminogênio para plasmina (Figura 1), no entanto uma taxa muito maior ocorre em leites com alta CCS (DE RHAM \& ANDREWS, 1982). ZACHOS et al. (1992) também concluíram que, durante a mastite severa, há maior ação do ativador de plasminogênio. A maior atividade da plasmina pode ocorrer no final da lactação, em vacas mais velhas e no leite mastítico, no qual os maiores níveis foram observados (BASTIAN \& BROWN, 1996). De acordo com URECH et al. (1999), quartos com mastite subclínica produzem leite com $20 \%$ a mais de plasmina ativada e $30 \%$ a mais de plasminogênio, e no leite mastítico a atividade dos ativadores de plasminogênio é cerca de oito vezes maior (ZACHOS et al., 1992). 
A plasmina, bem como a maior parte do plasminogênio, está intimamente associada às micelas de caseína no leite. Menores quantidades das enzimas estão presentes na fração sérica e na membrana lipídica, o que pode ser resultante da associação do plasminogênio e da plasmina a pequenas quantidades de caseína solúvel ou a micelas de caseína presentes nestas frações (POLITIS et al., 1992). A mastite provoca a dissociação das micelas de caseína, transferindo a plasmina e o plasminogênio para o soro. Porém, o grau de ativação do plasminogênio é maior quando este está associado às micelas de caseína em relação àquele solúvel, tanto em leites sadios quanto em leites mastíticos devido à provável presença de inibidores de plasmina e inibidores dos ativadores de plasminogênio (SCHAAR \& FUNKE, 1986).

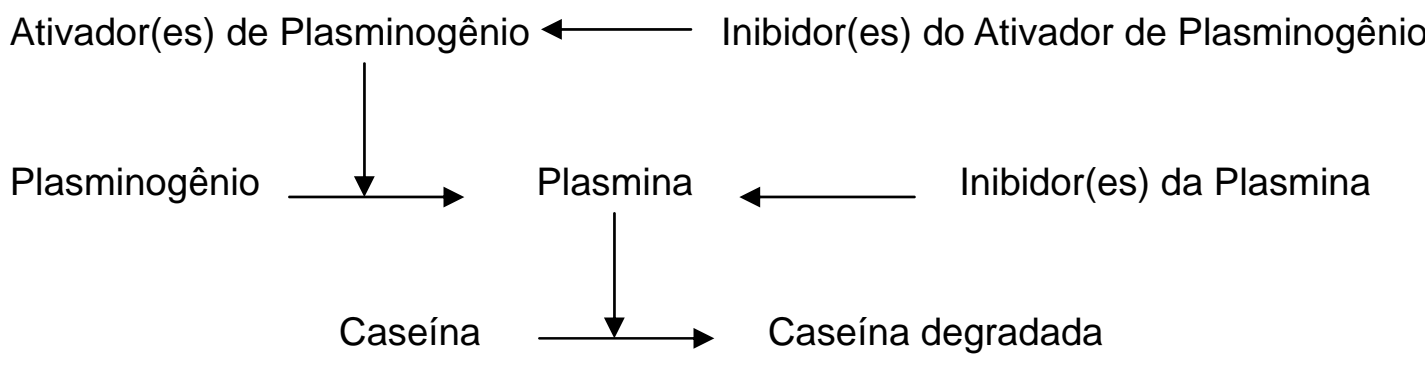

Figura 1. Representação esquemática do sistema da enzima plasmina no leite (BASTIAN \& BROWN, 1996).

Com relação à estabilidade térmica da plasmina e do plasminogênio, a pasteurização do leite $\left(72^{\circ} \mathrm{C}\right.$ por 15 segundos) resulta em um decréscimo de $10 \%$ (KORYCKA-DAHL et al., 1983) a 17\% na atividade da plasmina. A concentração de plasminogênio decresce durante o armazenamento do leite, sendo que a taxa de decréscimo no leite pasteurizado é maior do que no leite cru (RICHARDSON, 1983). A atividade do plasminogênio, de acordo com VERDI e BARBANO (1991b), pode ser anulada pelo aquecimento do leite a $63^{\circ} \mathrm{C}$ por 30 minutos. 
Parte da atividade proteolítica, entretanto, sobrevive à pasteurização (VERDI \& BARBANO, 1988), o que se deve, segundo BASTIAN e BROWN (1996), à característica de termorresistência da plasmina, que pode sobreviver até a tratamentos UHT. A estabilidade térmica da plasmina é pH dependente, sendo estável à pasteurização em pH ácido ou neutro, e rapidamente inativada em $\mathrm{pH}$ alcalino (MUIR, 1996). O leite pasteurizado possui maior atividade do ativador de plasminogênio em relação ao leite cru, diferença atribuída à desnaturação de um inibidor do ativador de plasminogênio pela pasteurização. Os ativadores de plasminogênio são estáveis ao pH e à temperatura, e estão predominantemente associados à fração de caseína (RICHARDSON, 1983).

SAEMAN et al. (1988) relataram que a atividade proteolítica total do leite permanece, após a cura da infecção, significativamente maior que a observada na pré-infecção, o que provavelmente é decorrente da atividade da plasmina. Os efeitos deletérios da mastite na qualidade do leite podem, portanto, continuar após a eliminação da infecção e o retorno dos níveis de CCS a valores baixos. De acordo com VERDI e BARBANO (1988), uma porção de atividade proteolítica das células somáticas sobrevive à pasteurização.

\subsubsection{Enzimas Lipolíticas}

A lipólise pode ser definida como a hidrólise enzimática da gordura. Fatores como a agitação mecânica do leite, nível de constituintes sangüíneos, estágio de lactação, nutrição, ciclo hormonal e mastite podem contribuir para a lipólise (DOWNEY, 1980). A secreção de enzimas lipolíticas por leucócitos no leite cru pode contribuir para a geração de ácidos graxos livres e promover a rancidez hidrolítica no leite (AZZARA \& DIMICK, 1984). 
As enzimas com atividade lipolítica, como a lipase lipoproteica (Enzyme Commission - 3.1.1.34), as lipases de origem das células somáticas e as microbianas, predispõem à ocorrência de sabor rançoso em função da quebra de ácidos graxos de cadeia longa em ácidos graxos de cadeia curta (RANDOLPH \& ERWIN, 1974; MURPHY et al., 1989; RENEAU \& PACKARD,1991). De fato, a LLP catalisa a quebra dos triglicerídeos do leite, produzindo ácidos graxos livres (AGL), sobretudo os de cadeia curta como o butírico, caprílico e capróico, os quais são responsáveis por alguns defeitos de sabor (DOWNEY, 1980; DEETH, 1993; MUIR, 1996) devido ao forte flavor que possuem (DEETH, 1993). Em avaliação sensorial do leite com $2 \%$ de gordura, de acordo com SANTOS et al. (2003b), 34\% dos provadores foram capazes de identificar defeitos de sabor causados pela lipólise, em concentrações de AGL de 0,25 meq/kg de leite.

A distribuição da LLP no leite e a suscetibilidade da gordura à lipólise estão relacionadas ao balanço entre ativadores e inibidores no leite, assim, o leite suscetível contém um baixo número de inibidores (CARTIER \& CHILLIARD, 1990). A LLP sérica, segundo ANDERSON (1982), é mais efetiva em promover lipólise do que a LLP ligada às micelas de caseína. A adição de LLP aos glóbulos de gordura do leite em quantidades correspondentes àquelas presentes no leite causa liberação de 0,5 a $2,5 \mu \mathrm{mol}$ de ácidos graxos $/ \mathrm{mL}$ durante incubação a $4^{\circ} \mathrm{C}$ por 24 horas (SUNDHEIN \& BENGTSSON-OLIVECRONA, 1987).

FITZ-GERALD et al. (1981) afirmam que o leite mastítico possui tendência a apresentar maiores níveis de AGL e menor atividade da LLP. No entanto, AZZARA e DIMICK (1985a) reportaram que a média de atividade da LLP no leite proveniente de quartos com mastite subclínica foi $27 \%$ maior do que a média de atividade da enzima no leite de quartos não mastíticos. De acordo com AZZARA e DIMICK (1985b), macrófagos isolados das secreções mamárias bovinas produzem enzimas 
que podem influenciar a atividade da LLP no leite cru no decorrer do armazenamento.

NEEDS et al. (1986) afirmam que o teor de gordura e a CCS não afetam o nível de lipólise, e que há um aumento significativo dos ácidos graxos saturados de cadeia longa no leite proveniente de quartos com infecção (NEEDS \& ANDERSON, 1984). Porém, RANDOLPH e ERWIN (1974) afirmam que leites positivos para mastite contêm maiores concentrações de AGL e ácidos graxos de cadeia curta, e menores concentrações de ácidos graxos de cadeia longa.

Outros autores reportaram que a concentração de AGL no leite de vacas com mastite é mais alta (TALLAMY \& RANDOLPH, 1969; RANDOLPH \& ERWIN, 1974), e há correlação com o nível de CCS (SALIH \& ANDERSON, 1979; BACHMAN et al., 1988). JURCZAK \& SCIUBIZ (1981) afirmam que apenas em determinados níveis de CCS nota-se correlação com a concentração de AGL e, de acordo com SALIH e ANDERSON (1979), a influência das células é progressivamente menor com o aumento da contagem.

A quantidade de ácidos graxos totais em leites provenientes de vacas com mastite é aproximadamente $4 \%$ menor, enquanto a de AGL é aproximadamente 47\% maior do que em leites negativos para mastite (RANDOLPH \& ERWIN, 1974). Adicionalmente, o acúmulo de AGL em amostras positivas no WMT é de 1,5 a 2,0 vezes mais rápido do que em amostras negativas (TALLAMY \& RANDOLPH, 1969).

Os triglicerídeos, que estão protegidos pela MGGL (DOWNEY, 1980), sofrem alterações de acordo com a severidade da infecção (KITCHEN, 1981). A presença de grande número de células no leite afeta a composição, resultando em menor quantidade de fosfolipídios (RANDOLPH \& ERWIN, 1974), bem como a estabilidade da MGGL (ANDERSON, 1977), o que pode influenciar a quantidade de substrato disponível para lipólise (SALIH \& ANDERSON, 1979). 
A composição da MGGL pode ser alterada por fatores relacionados ao animal, ao ambiente e ao processamento. Os fatores relacionados ao animal incluem a dieta, a estação do ano, o estágio da lactação e a raça da vaca. Fatores ambientais se referem à presença de bactérias no leite, provenientes de contaminações pré ou pós pasteurização, ou à presença de patógenos que provocam mastite. Finalmente, os fatores relacionados ao processamento incluem o resfriamento, a separação, a agitação, o aquecimento e a homogeneização (LEE \& SHERBON, 2002).

Modificações na composição da MGGL do leite com alta CCS podem ocorrer como resultado direto de enzimas leucocíticas extracelulares no leite, conseqüente a uma liberação direta da célula intacta, ou da lise dos leucócitos (ANDERSON, 1977). O leite mastítico contém aproximadamente 10\% a menos de MGGL comparado ao leite normal (ERWIN \& RANDOLPH, 1975).

De acordo com JURCZAK e SCIUBISZ (1981), a lipólise no leite mastítico deve-se ao fenômeno da lipólise espontânea e daquela resultante da atividade das lipases intracelulares que, infiltradas no leite como conseqüência da lise das células somáticas, degradam a gordura. A lipólise espontânea se desenvolve sem que ocorra agitação mecânica do leite cru e é iniciada pelo resfriamento do leite fresco (DOWNEY, 1980). A lipólise induzida é usualmente associada à injúria da MGGL, que pode ocorrer através da agitação, com conseqüente incorporação de ar no leite e rompimento da MGGL (DOWNEY, 1980; DEETH, 1993).

No leite de boa qualidade microbiológica (contendo até $5 \times 10^{3} \mathrm{ufc} / \mathrm{mL}$ ) ou de qualidade razoável $\left(<10^{5} \mathrm{ufc} / \mathrm{mL}\right.$ ), enzimas lipolíticas intrínsecas do leite são primariamente responsáveis pelos defeitos que podem ser desenvolvidos durante o armazenamento sob refrigeração. Contagens acima de $10^{6}$ ou $10^{7} \mathrm{ufc} / \mathrm{mL}$ são 
requeridas no leite para que apenas as enzimas microbiais causem significativa lipólise (DOWNEY, 1980).

Embora os mecanismos não estejam bem determinados, está claro, segundo MURPHY et al. (1989), que a mastite, e conseqüentemente a resposta inflamatória, causa aumento na lipólise espontânea. Mas uma vez que a infecção seja eliminada e os níveis de células somáticas retornem aos níveis de préinfecção, o leite retornará às características lipolíticas de antes de a vaca ser infectada. A mudança na composição química do leite mastítico parece exercer um efeito inibitório na extensão da lipólise (JURCZAK \& SCIUBISZ, 1981).

Outros autores concordam que a mastite causa aumento da atividade lipolítica no leite (TALLAMY \& RANDOLPH, 1969; RANDOLPH \& ERWIN, 1974). Por outro lado, DEETH (1993) afirma que no iogurte poucos problemas são causados pela ação da lipase, porém não menciona a possível influência da CCS.

De acordo com SHIPE \& SENYK (1981), aumentos na lipólise são substanciais no leite pasteurizado durante o armazenamento. Processamentos a $76,7^{\circ} \mathrm{C}$ por 16 segundos são adequados para proteger o leite da lipólise por sete dias após a pasteurização, porém maiores temperaturas podem ser necessárias para garantir maior tempo de prateleira em leites suscetíveis. DEETH (1993) afirma que a lipase do leite é inativada pela pasteurização, não causando lipólise no leite pasteurizado e produtos derivados. Porém, CASTBERG (1992) reportou que a lipase nativa não é completamente inativada em condições de pasteurização HT-ST (high temperature - short time), enquanto que a lipase de origem bacteriana sobrevive ao tratamento UHT. 


\subsection{Viscosidade}

A reologia é o estudo da deformação dos materiais submetidos à aplicação de forças. A viscosidade é a medida da fricção interna do fluido (LEWIS, 1993). A friç̧ão se torna aparente quando uma camada de fluido passa a se mover em relação a outra camada. A força necessária para causar este movimento é denominada cisalhamento. Portanto, fluidos de maior viscosidade requerem mais força para o movimento do que materiais menos viscosos (BROOKFIELD, sem data).

A viscosidade é a propriedade inversa da fluidez, ou seja, é a resistência do alimento a sofrer deslocamentos quando submetido a uma força externa, como a agitação (BOBBIO \& BOBBIO, 1995). A viscosidade aparente, parâmetro para a mensuração de fluidos não-Newtonianos, é usualmente determinada por viscosímetros rotacionais (ROHM, 1992). O iogurte batido pode ser classificado como um fluido não-Newtoniano (HELLINGA et al., 1986) que exibe um comportamento tempo-dependente (ROHM, 1992).

A viscosidade é um importante atributo de qualidade do iogurte batido, podendo ser afetada por uma série de parâmetros tecnológicos (ROHM, 1992). A textura do coágulo é uma importante característica do iogurte natural, determinando a identidade e a aceitação do produto (SHAKER et al., 2000).

Dependendo do processo e da intensidade do aquecimento do leite, uma determinada proporção de $\beta$-lactoglobulina e $\alpha$-lactoalbumina é ligada à caseína. Os filamentos desnaturados de $\beta$-lactoglobulina se desenvolvem na superfície da micela, o que oferece uma barreira à fusão das micelas quando o leite é fermentado, resultando em uma textura inferior do iogurte. Porém, em maiores intensidades de aquecimento, os filamentos de $\alpha$-lactalbumina também precipitam na micela, preenchendo as aberturas formadas pelos filamentos de $\beta$ - 
lactoglobulina, resultando em uma superfície micelar mais macia (MOTTAR et al., 1989).

Durante a fermentação, a coalescência das micelas melhora a textura. A associação, induzida pelo calor, da $\alpha$-lactalbumina com as partículas de caseína parece ser importante para a fusão e hidratação das micelas durante a subseqüente fermentação, o que determina as propriedades reológicas do iogurte (MOTTAR et al., 1989). CHENG et al. (2002) reportaram uma correlação positiva entre a viscosidade do iogurte batido e a concentração de caseína.

Um tempo muito longo de incubação resulta em uma coagulação que reduz a viscosidade aparente. A viscosidade diminui com o aumento no tamanho das partículas e com a diminuição da velocidade de fermentação. A quebra da estrutura está diretamente relacionada à geometria do equipamento utilizado e às condições de processamento, como temperatura e fluxo (BENEZECH \& MAINGONNAT, 1994). WOLFSCHOON-POMBO et al. (1983) afirmam que a viscosidade, a consistência e a estabilidade do iogurte podem ser influenciadas por fatores como a homogeneização, o tratamento térmico, a acidificação, a temperatura de incubação e as condições de armazenamento. Além disso, a adição de 2 a 3\% de leite em pó ao leite resulta em maior termodesnaturação das soroproteínas, porém não em maior viscosidade.

Quanto aos efeitos da CCS na viscosidade de produtos lácteos, os dados disponíveis na literatura são conflitantes. CHRISTEN e NDOMBA (1991), em estudo com leite UHT, concluíram que quanto maior a CCS, menor a viscosidade do produto. KOHLMANN et al. (1991) reportaram que a adição de plasmina no leite UHT causa formação de gel a partir de 90 dias de armazenamento, e esta geleificação é acompanhada de aumento na viscosidade aparente. OLIVEIRA et al. (2002) reportaram que a consistência do iogurte batido contendo alta CCS recebeu 
menores notas a partir do $10^{\circ}$ dia de armazenamento, quando submetido à avaliação sensorial, em relação ao produto contendo baixas contagens. Ressalta-se que a medida instrumental e sensorial da viscosidade, segundo PENNA et al. (1996), apresenta resultados semelhantes e correlacionáveis $(r=0,65)$ entre si.

GASSEM \& FRANK (1991) observaram que o iogurte produzido com leite previamente tratado com proteases microbianas apresentou maior firmeza, sinérese e viscosidade aparente do que o produto com leite não tratado. O iogurte produzido com leite adicionado de plasmina demonstrou, além de menor firmeza, significativamente menor viscosidade aparente e, após oito dias, menor sinérese comparado ao grupo controle. Já no iogurte produzido com leite contendo as duas proteases, observou-se menor capacidade de retenção de água e hidratação da proteína do que no grupo controle. Conclui-se, portanto, que a proteólise do leite resulta em um iogurte com substanciais diferenças nas propriedades físicas.

\subsection{Aspectos da Tecnologia de Fabricação de logurtes}

A acidificação do leite pela fermentação é um dos mais antigos métodos de preservação do leite, o qual adquire com isto qualidades organolépticas especiais (TAMIME \& DEETH, 1980). O leite fermentado foi desenvolvido há muitos anos nas regiões do Mediterrâneo, Oriente Médio e Índia, sendo conhecido como laban ou leben no Líbano e regiões adjacentes, Iben no Marrocos, dahi na Índia e zabadi no Egito. O iogurte, principal tipo de leite fermentado desenvolvido nas últimas décadas, e que tem obtido grande sucesso na aceitação mundial, pode ser considerado similar aos produtos citados, apresentando como diferença o fato da utilização de uma cultura starter termofílica definida (TAMIME \& ROBINSON, 1988).

logurte é o produto lácteo coagulado obtido através da ação de Lactobacillus bulgaricus e Streptococcus thermophilus em leite, no qual podem ser adicionados 
alimentos ou outros ingredientes permitidos. Os microrganismos no produto final têm que ser viáveis e abundantes (FOOD AND AGRICULTURE ORGANIZATION, 2003).

O iogurte, segundo BRANDÃO (1995), é de mais fácil digestibilidade do que o leite, visto que cerca de $50 \%$ da concentração original de lactose é hidrolisada durante a fermentação. As propriedades de alguns tipos de iogurte incluem a prevenção de diarréias, gastroenterites e constipações, além de, possivelmente, apresentarem efeitos hipocolesterolêmicos e anticarcinogênicos.

\subsubsection{Tipos de iogurte}

De acordo com algumas variações nas etapas de elaboração, pode-se obter diferentes tipos de iogurtes. Os tipos variam de acordo com a composição química, o método de produção, o flavor e a natureza do processamento pósincubação. A classificação em dois principais tipos de iogurte, consistente e batido, é baseada na estrutura física do coágulo (TAMIME \& DEETH, 1980). O iogurte consistente é incubado já na embalagem, podendo ser adicionado de frutas e então refrigerado, enquanto que o iogurte batido é incubado em tanque, agitado para haver quebra do coágulo, adicionado ou não de xarope de frutas e finalmente envasado e refrigerado (SPREER, 1991; ROBINSON \& TAMIME, 1993).

\subsubsection{Padronização do Teor de Sólidos Totais}

A tecnologia de fabricação de iogurtes envolve várias etapas de elaboração, iniciando-se pela padronização do teor de sólidos totais, cuja finalidade é melhorar a consistência final do iogurte, diminuir a sinérese e reduzir ligeiramente a produção de ácido durante a fermentação (VARNAM \& SUTHERLAND, 1994). 
A padronização do teor de sólidos totais pode se dar pela adição de leite em pó ou pela concentração do leite (ROBINSON \& TAMIME, 1993). O leite em pó pode ser adicionado em concentrações de 3 a 4\%. A desvantagem deste método é a possibilidade de excessiva produção de ácido devido ao aumento da concentração de lactose. A concentração do leite pode ser realizada por evaporação. Outros métodos de fortificação do extrato seco incluem a adição de soro em pó, a ultrafiltração ou a osmose reversa (TAMIME \& DEETH, 1980).

\subsubsection{Homogeneização do leite}

A homogeneização do leite, realizada antes do tratamento térmico, promove uma dispersão homogênea dos constituintes do leite, estabilizando o coágulo e, conseqüentemente, impedindo a separação da nata durante a incubação. A qualidade organoléptica aumenta, assim como a viscosidade do produto final (TAMIME \& DEETH, 1980; ROBINSON \& TAMIME, 1993; VARNAM \& SUTHERLAND, 1994). A homogeneização é particularmente importante quando se utiliza leite em pó para padronização do extrato seco (TAMIME \& DEETH, 1980).

\subsubsection{Tratamento térmico}

O tratamento térmico do leite elimina microrganismos patogênicos causadores de toxiinfecções, como a Salmonella e o Campylobacter (VARNAM \& SUTHERLAND, 1994). Há também eliminação de microrganismos vegetativos que poderiam competir com a cultura starter, além de expulsar o oxigênio do leite, criando condições para o desenvolvimento da cultura (ROBINSON \& TAMIME, 1993; VARNAM \& SUTHERLAND, 1994).

Durante o tratamento térmico, a $\beta$-lactoglobulina interage com a $\kappa$-caseína, havendo também participação da $\alpha$-lactalbumina. Esta interação aumenta as propriedades hidrofílicas da caseína e facilita a formação de um coágulo estável, 
com menor sinérese. A maioria das proteínas séricas é desnaturada, sendo que a $\beta$-lactoglobulina é quase completamente desnaturada (TAMIME \& DEETH, 1980; VARNAM \& SUTHERLAND, 1994; BRANDÃO, 1995).

Para que a desnaturação das proteínas séricas ocorra, é necessário o aquecimento do leite a temperaturas superiores a $75^{\circ} \mathrm{C}$. O tratamento térmico considerado ótimo atinge $95^{\circ} \mathrm{C}$ por 15 minutos, proporcionando melhores resultados de consistência (SPREER, 1991). O aquecimento também diminui o tempo de coagulação devido, em parte, ao abaixamento do pH (TAMIME \& DEETH, 1980).

\subsubsection{Incubação}

Efetuado o tratamento térmico, segue-se o resfriamento parcial e a inoculação com a cultura starter, que contém os microrganismos Streptococcus salivarius ssp. thermophilus e Lactobacillus delbruekii ssp. bulgaricus, responsáveis pela fermentação láctica (SPREER, 1991; ROBINSON \& TAMIME, 1993). Há uma relação sinérgica entre os microrganismos. O Streptococcus é estimulado por aminoácidos e peptídeos liberados da caseína pelo Lactobacillus, que por sua vez é estimulado pelo ácido fórmico produzido pelo Streptococcus (SOUZA, 1991; VARNAM \& SUTHERLAND, 1994). A proporção dos microrganismos na cultura deve ser de 1:1 (SPREER, 1991; SOUZA, 1991) e a temperatura ótima de incubação é de 42 a 44 C (SOUZA, 1991; BRANDÃO, 1995).

Durante a coagulação, de acordo com TAMIME \& DEETH (1980), a lactose é hidrolisada, dentro da célula bacteriana, pela enzima $\beta$-D-galactosidase, gerando glicose e galactose. A glicose é metabolizada em ácido pirúvico, o qual é convertido em ácido lático. Este auxilia na desestabilização da micela de caseína, conduzindo à coagulação das proteínas e formação do gel. O sabor e aroma do iogurte também 
são devidos ao ácido lático, além de pequenas quantidades de acetaldeído, diacetil e ácido acético.

As bactérias produtoras de ácido lático podem causar um significativo grau de proteólise em muitos produtos fermentados, incluindo o iogurte (TAMIME \& DEETH, 1980). A atividade proteolítica dos cultivos starter é importante pela liberação de peptídeos de tamanho variado e aminoácidos livres, que afetam a estrutura física do iogurte. A liberação de aminoácidos no leite é essencial para o crescimento do S. thermophilus. Os aminoácidos e peptídeos atuam também como precurssores das reações que conduzem à formação de compostos responsáveis pelo flavor do iogurte (TAMIME \& ROBINSON, 1991).

A proteólise no iogurte causada pelas bactérias do cultivo starter aumenta a quantidade de nitrogênio não-proteico solúvel. O Lactobacillus bulgaricus é o mais proteolítico dos microrganismos do iogurte e possui habilidade para hidrolisar a caseína. O Streptococcus thermophilus, embora apresente limitada atividade de proteinases, possui atividade de peptidases e pode hidrolisar os produtos intermediários da degradação da caseína. A maior parte da proteólise ocorre nas primeiras 24 a 48 horas após a fabricação (TAMIME \& DEETH, 1980).

Com a lipase natural do leite completamente inativada pela pasteurização, a lipólise no iogurte pode ser atribuída às enzimas lipolíticas das bactérias starter. As lipases das bactérias produtoras de ácido lático demonstram preferência por triglicerídeos de cadeia curta, além de possuírem maior atividade contra glicerídeos em relação a triglicerídeos. Porém, parece haver apenas um pequeno grau de lipólise no iogurte, sendo a maioria dos ácidos voláteis do produto derivados de componentes não gordurosos (TAMIME \& DEETH, 1980).

O leite contendo alta CCS pode causar uma redução na atividade da cultura starter de até 35\%. Além disso, a presença de altos níveis de AGL no leite pode ser 
prejudicial à quantidade de proteólise gerada pelos microrganismos da cultura starter e à qualidade do iogurte. O ácido cáprico possui efeito inibitório na proteólise provocada pelo L. bulgaricus, sozinho ou em combinação com o S. thermophilus, e afeta a textura do coágulo (TAMIME \& DEETH, 1980).

\subsubsection{Resfriamento}

O resfriamento é realizado imediatamente após o produto atingir a acidez desejável. O objetivo desta etapa é reduzir a atividade metabólica da cultura starter (TAMIME \& DEETH, 1980).

Os critérios de avaliação da qualidade do iogurte, segundo KROGER (1976), devem incluir avaliações sensoriais (sabor, aroma, aparência visual, corpo e textura), acidez titulável e pH, análises de composição (teores de gordura, proteínas e sólidos totais), contagem de coliformes (totais e fecais) e avaliação da vida de prateleira após quatro dias de armazenamento a $15^{\circ} \mathrm{C}$. 


\section{MATERIAL E MÉTODOS}

\subsection{Obtenção do Leite e Adequação dos Níveis de CCS}

O leite utilizado no trabalho foi obtido a partir do rebanho leiteiro disponível no Campus Administrativo da USP em Pirassununga, constituído então por 40 vacas em lactação, da raça Holandesa, com produção média de 800 L/dia. Foram selecionadas, dentre os animais que se apresentavam em estágios intermediários da lactação, e que não foram submetidos ao tratamento com antibióticos nos sete dias anteriores, vacas produtoras de leite com baixa CCS ( $<400.000$ células/mL), com níveis intermediários $(400.000-800.000$ células/mL) e com alta CCS (>800.000 células/mL).

Para a seleção dos animais, foram colhidas amostras de leite de cada vaca em lactação e enviadas ao Laboratório de Fisiologia da Lactação do Departamento de Produção Animal da Escola Superior de Agronomia Luiz de Queiroz (ESALQ) / USP, em Piracicaba/SP, com vistas à realização da contagem de CS, através de contador eletrônico de células somáticas (Somacount, Bentley ${ }^{\circledR}$, EUA), e análise da composição físico-química do leite. Este procedimento foi realizado para que fosse efetuada a seleção das vacas com alta, média e baixa CCS, garantindo-se uma composição homogênea do leite dos diferentes grupos. A colheita das amostras individuais foi efetuada em duas ordenhas, manhã e tarde, com homogeneização do leite por no mínimo 10 segundos no balão medidor e 
posterior colheita em frascos de $60 \mathrm{~mL}$, previamente enviados pela ESALQ, contendo dicromato de potássio como conservante.

As vacas selecionadas foram submetidas à ordenha três dias após as colheitas para análises de CCS e composição, para a obtenção do leite necessário ao experimento, sendo cada grupo ordenhado separadamente. A obtenção do leite foi realizada em sala de apropriada, pertencente ao Campus, contendo todos os equipamentos necessários para a ordenha mecânica. O leite de cada grupo de vacas foi recolhido em latões de polipropileno higienizados, de capacidade de 50 litros cada, em duas ordenhas, manhã e tarde, totalizando 50 litros. Após a obtenção do leite, os latões foram imediatamente transferidos para câmara fria a $5^{\circ} \mathrm{C}$, para resfriamento e armazenamento até o momento de sua utilização.

Complementarmente, as condições sanitárias do leite produzido no local foram avaliadas antes do início do experimento, através da colheita asséptica de amostras (250 $\mathrm{mL}$ cada) retiradas diretamente do tanque de refrigeração, durante três dias consecutivos. As amostras foram imediatamente submetidas ao exame microbiológico para a contagem de microrganismos mesófilos e psicrotróficos, de acordo com os procedimentos descritos pela AMERICAN PUBLIC HEALTH ASSOCIATION - APHA (1992).

\subsection{Elaboração do logurte Batido}

\subsubsection{Preparo das Condições Experimentais}

Antes do início dos processamentos, foram efetuadas análises microbiológicas nos principais pontos de contaminação da linha de produção de iogurte (iogurteira, tubulações, bombas de transferência e envasadora de garrafas), com a finalidade de assegurar a higiene dos produtos. Além disso, realizou-se a desmontagem, a higienização e a sanitização minuciosa de toda a linha de 
processamento, antes e a após a fabricação de cada lote de iogurte. Com isso, foi possível garantir a qualidade microbiológica dos iogurtes e evitar possíveis interferências nos resultados gerados no experimento.

Os três tipos de leites, obtidos nas condições estabelecidas no item anterior, foram utilizados para a fabricação do iogurte, que se realizou no Setor de Laticínios do Campus, 24 horas após a ordenha. Cada tipo de leite foi processado separadamente de acordo com os procedimentos descritos por SPREER (1991), detalhados a seguir.

\subsubsection{Padronização do Leite}

Foram efetuadas análises físico-químicas do leite, para a determinação da acidez titulável, pH, densidade a $15^{\circ} \mathrm{C}$, índice crioscópico (IC), teores de gordura e proteína, sólidos totais (ST) e sólidos não gordurosos (SNG), conforme as técnicas preconizadas pelo INSTITUTO ADOLFO LUTZ (1985).

Em seguida, o conteúdo total dos latões foi vertido em tanque de recepção provido com sistema de bombeamento, e acoplado à iogurteira de capacidade 500 litros. Foi acrescido ao leite quantidade suficiente de leite em pó desnatado necessária para atingir a densidade mínima de 1,035. Este procedimento é adotado regularmente na indústria com a finalidade de reforçar o extrato seco total e, conseqüentemente, auxiliar a formação de gel estável e de consistência típica para o produto (SPREER, 1991).

\subsubsection{Tratamento Térmico do Leite}

$\mathrm{Na}$ iogurteira, na qual foram efetuados os procedimentos de fabricação do iogurte, o leite foi submetido à temperatura de $90^{\circ} \mathrm{C}$, por 15 minutos, seguido de 
resfriamento para cerca de $45^{\circ} \mathrm{C}$. Após este procedimento, foram colhidas duas amostras $(250 \mathrm{~mL})$ do leite para exame microbiológico. Este incluiu a contagem de mesófilos, psicrotróficos e a determinação do Número Mais Provável (NMP) de coliformes a 30 e $45^{\circ} \mathrm{C}$, de acordo com a metodologia preconizada pela APHA (1992).

A contagem de mesófilos foi efetuada mediante a semeadura, em placas, de $1 \mathrm{~mL}$ das diluições $\left(10^{-1}\right.$ e $10^{-2}$, previamente realizadas em água peptonada), seguida da adição de agar PCA e incubação a $35^{\circ} \mathrm{C}$ por 48 horas para posterior contagem das colônias. A contagem de psicrotróficos foi realizada de modo similar, porém com incubação à temperatura de $7^{\circ} \mathrm{C}$ por 10 dias.

A determinação do NMP de coliformes totais foi realizada observando-se a formação de bolhas de gás nos tubos de Duhran invertidos contidos no tubo de ensaio com o caldo Lauril Sulfato. Eram adicionados nos tubos $1 \mathrm{~mL}$ de amostra, 1 $\mathrm{mL}$ da diluição $10^{-1}$ ou $1 \mathrm{~mL}$ da diluição $10^{-2}$, conforme a seqüência de tubos. Estes eram incubados em estufa a $30^{\circ} \mathrm{C}$ por 48 horas para que se procedesse a leitura. $\mathrm{A}$ determinação de coliformes fecais procedeu-se de modo semelhante, porém com repique dos tubos positivos no exame anterior em caldo EC, e incubação a $45^{\circ} \mathrm{C}$ em banho-maria por 24 horas para se efetuar a leitura.

\subsubsection{Semeadura, Incubação e Embalagem}

O cultivo lácteo (Jo-Mix VM, Visbyvac ${ }^{\circledR}$, Alemanha) foi adquirido na forma liofilizada, contendo as bactérias Streptococcus salivarius ssp. thermophilus e Lactobacillus delbruekii ssp. bulgaricus. A cultura mãe foi preparada através de semeadura direta de 0,40 mg em 1 litro de leite, previamente aquecido a $90^{\circ} \mathrm{C}$ por 30 minutos, seguido de incubação a $42^{\circ} \mathrm{C}$ por aproximadamente três horas, até alcançar o valor de $\mathrm{pH}$ de 4,50 a 4,65. Esta cultura foi mantida em temperatura 
inferior a $10^{\circ} \mathrm{C}$, sendo utilizada para o preparo do cultivo starter na semana de produção de iogurte, através da semeadura de 3\% em $10 \mathrm{~L}$ de leite, nas mesmas condições descritas anteriormente.

Para a produção do iogurte, foram acrescidos 1,5 $\mathrm{L}$ de cultivo starter (Figura 2) para o volume de $50 \mathrm{~L}$ leite presente na iogurteira (3\%), seguido de homogeneização e incubação a $42^{\circ} \mathrm{C}$, por aproximadamente três horas, até ser atingido o pH de 4,50 a 4,65. O produto foi então agitado mecanicamente para a quebra do coágulo (Figura 3) e resfriado a $15^{\circ} \mathrm{C}$ na própria iogurteira. Em seguida, o iogurte foi transferido por bombeamento para uma envasadora automática acoplada à iogurteira, e envasado em garrafas de polietileno de capacidade 1.000 $\mathrm{mL}$ (Figura 4).

A elaboração dos iogurtes, conforme descrito, foi repetida seis vezes no período de março a agosto de 2003 , totalizando seis lotes de iogurte para cada nível de CCS definido no experimento.

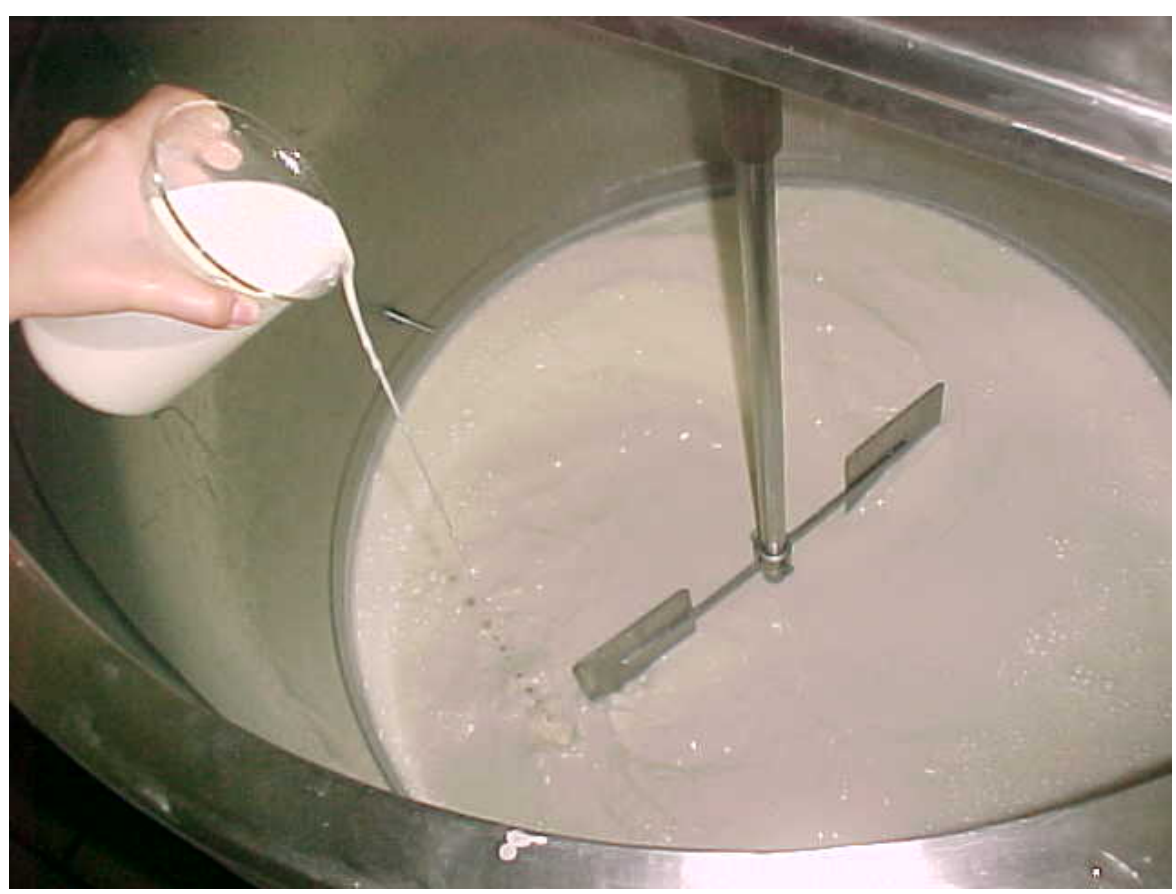

Figura 2. Adição de cultivo starter ao leite contido na iogurteira. 


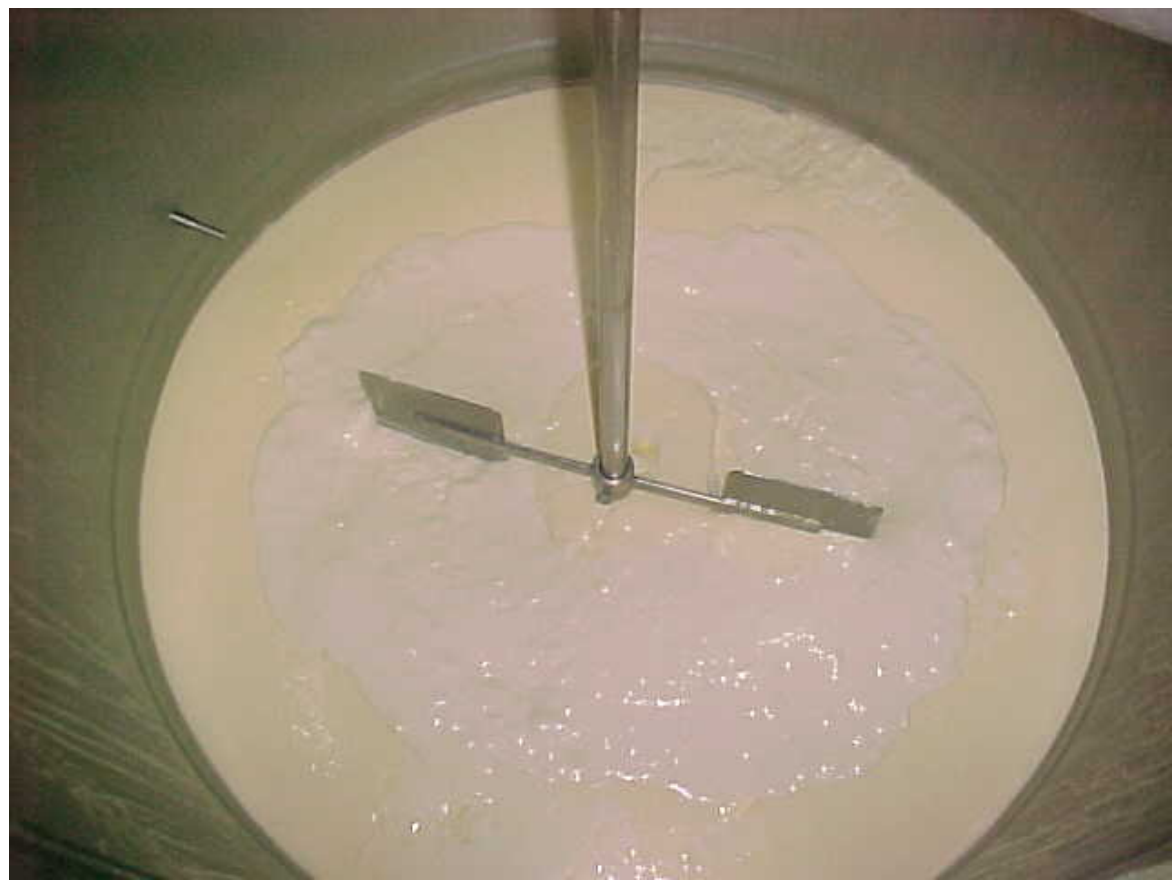

Figura 3. Agitação para a quebra do coágulo.

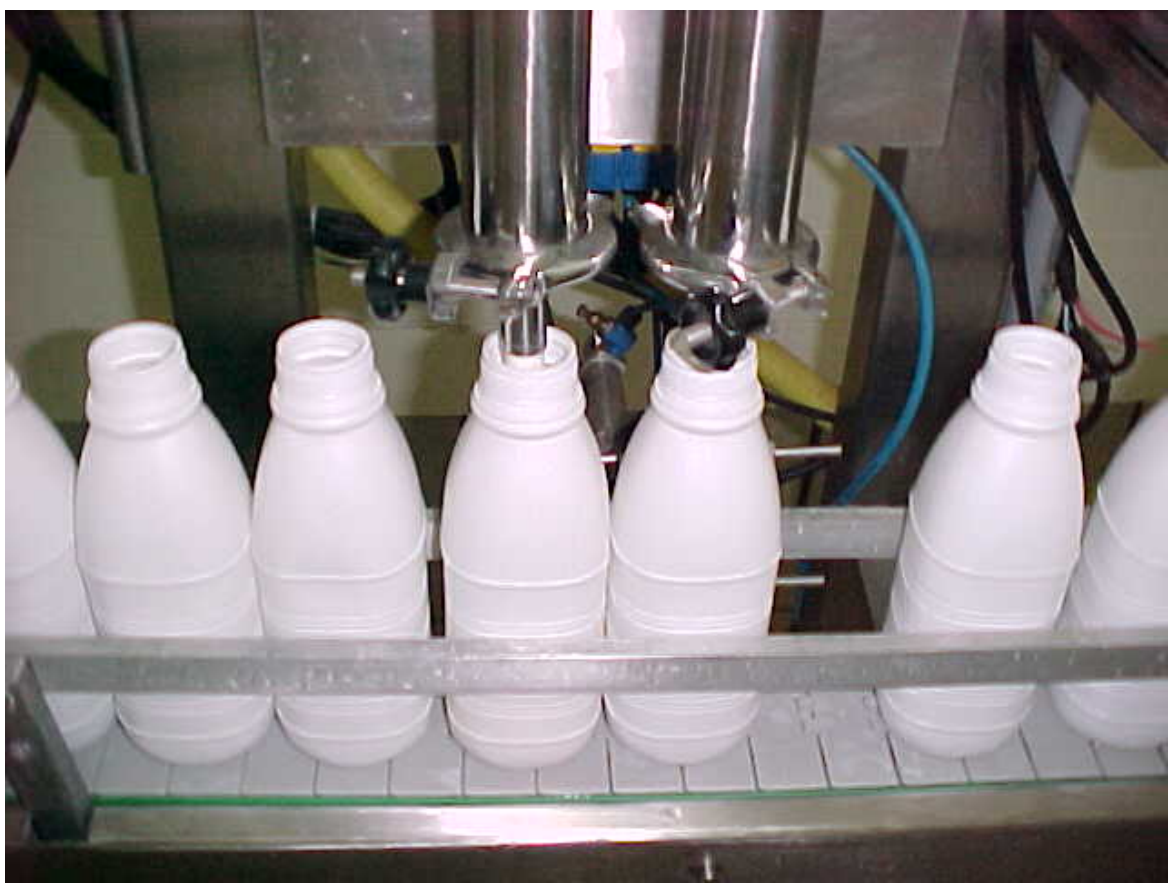

Figura 4. Detalhe mostrando o envase do iogurte. 


\subsection{Avaliação da Qualidade do logurte Batido}

O iogurte processado foi armazenado em câmara fria (Figura 5) à temperatura de $5^{\circ} \mathrm{C}$, por 30 dias, desprezando-se os primeiros 10 litros produzidos em cada lote. Foram colhidas três amostras por lote do produto 24 horas após a fabricação, bem como nos dias 10, 20 e 30, com vistas à execução das análises descritas a seguir.

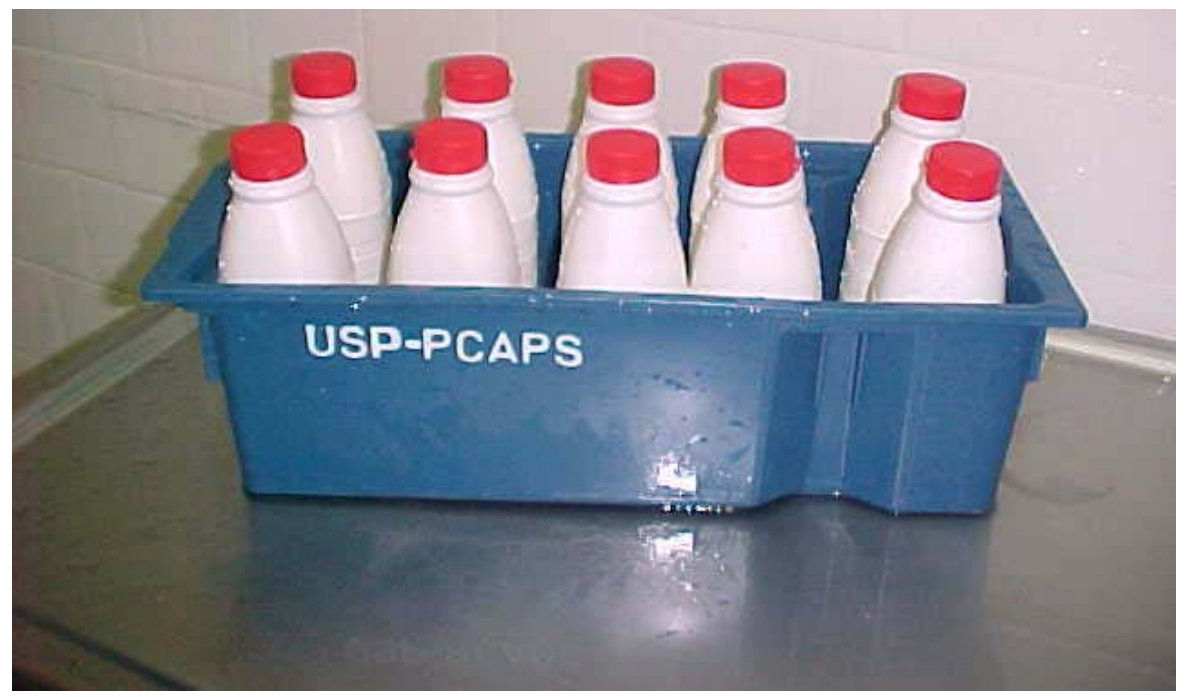

Figura 5. logurtes armazenados em câmara fria.

\subsubsection{Avaliação Físico-química}

De acordo com as técnicas descritas pelo INSTITUTO ADOLFO LUTZ (1985), as análises físico-químicas do iogurte incluíram as seguintes determinações: pH, através da utilização de um pHmetro modelo Tec-2 (Tecnal ${ }^{\circledR}$ ); acidez titulável, obtida pelo cálculo do percentual de ácido lático na amostra a partir do valor obtido na titulação da mesma com $\mathrm{NaOH} 0,1 \%$ até atingir o $\mathrm{pH} 8,3$; percentual de gordura, obtido pelo método de Gerber; ST, obtido pelo método 
gravimétrico; e SNG, calculado pela diferença entre o valor de ST e o percentual de gordura. A proteína total foi determinada pelo método de Kjeldahl, conforme metodologia descrita pela ASSOCIATION OF OFFICIAL ANALYTICAL CHEMISTS AOAC (1995).

\subsubsection{Avaliação da Proteólise}

A proteólise foi estimada através da relação caseína (C) / proteína verdadeira $(P V)$, expressa em termos de nitrogênio $(N)$ - equivalente de proteína, cujos valores foram obtidos conforme descrito abaixo:

$P V=[$ Nitrogênio Total (NT) - Nitrogênio Não Protéico (NNP)] x 6,38

$C=[$ Nitrogênio Total (NT) - Nitrogênio Não Caseinoso (NNC) $] \times$ 6,38

As amostras foram analisadas em duplicata. Para a determinação do NT, utilizou-se o método de Kjeldahl, conforme metodologia preconizada pela AOAC (1995), descrita a seguir. Cerca de 0,1 g da amostra foi pesada, em balança analítica, diretamente no tubo de micro-Kjeldahl, anotando-se o valor obtido. Foram então adicionados ao tubo $1 \mathrm{~g}$, aproximadamente, de mistura catalisadora constituída de sulfato de cobre e sulfato de potássio, e $3 \mathrm{~mL}$ de ácido sulfúrico concentrado. O tubo foi então levado ao bloco digestor para aquecimento por um período de aproximadamente quatro horas. Posteriormente, os tubos já resfriados à temperatura ambiente foram adicionados de $10 \mathrm{~mL}$ de água destilada e homogeneizados para, em seguida, proceder-se a destilação. Esta etapa incluiu a adição de cerca de $25 \mathrm{~mL}$ de hidróxido de sódio $50 \%$ e coleta do destilado em erlenmeyer contendo $15 \mathrm{~mL}$ de solução de ácido bórico 2\%, utilizando-se vermelho de metila e verde de bromocresol como corantes. A titulação do destilado foi efetuada com ácido clorídrico 0,2 N, obtendo-se os valores que, multiplicados por 6,18 , indicam a concentração de proteína total. 
A determinação do NNP foi efetuada após pesagem de cerca de $5 \mathrm{~mL}$ da amostra em becker, anotando-se o peso. A precipitação das proteínas do iogurte foi então conduzida através da adição de $5 \mathrm{~mL}$ de água destilada e $10 \mathrm{~mL}$ de ácido tricloroacético a 15\%, seguindo-se um repouso de 15 minutos antes da etapa de filtração em papel de filtro quantitativo, $n \cdot{ }^{\circ} 42$, para posterior análise de $5 \mathrm{~mL}$ do filtrado através do método de Kjeldahl (AOAC, 1995).

A determinação do NNC foi efetuada através do procedimento descrito por LYNCH \& BARBANO (1998), os quais preconizam a precipitação da caseína com solução de ácido acético e acetato de sódio $(\mathrm{pH}=4,6)$. Uma alíquota de $10 \mathrm{~mL}$ de amostra previamente aquecida a cerca de $38^{\circ} \mathrm{C}$ foi pesada em balão volumétrico de $100 \mathrm{~mL}$, adicionada de $75 \mathrm{~mL}$ de água destilada a $40^{\circ} \mathrm{C}$ e $1 \mathrm{~mL}$ de ácido acético $10 \%$, seguindo-se um repouso de 10 minutos em banho-maria a $40^{\circ} \mathrm{C}$. Após esta etapa, foi adicionado ao balão $1 \mathrm{~mL}$ de acetato de sódio $1 \mathrm{~N}$, seguido de resfriamento a temperatura ambiente para que o volume do balão fosse completado com água destilada a temperatura ambiente e se procedesse a filtração em papel de filtro qualitativo, n. ${ }^{\circ}$ 1. A análise da concentração de nitrogênio em $5 \mathrm{~mL}$ do filtrado foi então efetuada mediante o método de Kjeldahl. O resultado final (NNC) foi subtraído do valor de NT, fornecendo assim a concentração de caseína na amostra.

\subsubsection{Avaliação da Lipólise}

A lipólise do iogurte foi estimada através da alteração nas concentrações de AGL no produto ao longo do período de armazenamento. As amostras foram analisadas em triplicata, de acordo com a metodologia colorimétrica do sabão de cobre, descrita por SHIPE et al. (1980). Uma alíquota de $0,5 \mathrm{~mL}$ da amostra foi transferida para um tubo de ensaio contendo $0,1 \mathrm{~mL}$ de ácido clorídrico 0,7 N. Em 
seguida, $6 \mathrm{~mL}$ do solvente $\mathrm{CHM}$ (clorofórmio:heptano:metanol 49:49:2) foram adicionados ao tubo, e este foi brevemente homogeneizado. Foram então adicionados $2 \mathrm{~mL}$ do reagente cobre (trietanolamina e nitrato de cobre com $\mathrm{pH} 8,3$ ) ao tubo, que foi novamente homogeneizado e submetido, horizontalmente, à agitação constante por 30 minutos a $240 \mathrm{rpm}$. Os tubos foram centrifugados por 10 minutos para posterior retirada de $3 \mathrm{~mL}$ do sobrenadante, o qual foi adicionado a um novo tubo contendo $0,1 \mathrm{~mL}$ de corante, constituído de álcool $\mathrm{N}$-butílico e dietiltiocarbamato de sódio. Foi efetuada então, a leitura da absorbância a 440 nm, em espectrofotômetro, e os valores convertidos em meq/L de AGL utilizando-se a equação obtida através da construção da curva de calibração, utilizando-se ácido palmítico como padrão nas concentrações de 0, 0,156, 0,313, 0,468 e 0,624 meq/L. A equação e a curva de calibração podem ser observadas na Figura 8 (Capítulo 4, item 4.2.3).

\subsubsection{Avaliação da Viscosidade}

A viscosidade aparente do iogurte foi determinada a $5^{\circ} \mathrm{C}$ (PELEGRINE et al., 2000), utilizando-se um viscosímetro rotacional Brookfield ${ }^{\circledR}$, modelo DV-II+ (Figura 6). Cerca de $500 \mathrm{~mL}$ da amostra, previamente homogeneizada, foram transferidos para um becker forma baixa, com capacidade de $600 \mathrm{~mL}$, e em seguida procederam-se as leituras, as quais foram tomadas por um período de 30 minutos, a cada intervalo de 30 segundos. Foi utilizada para esta finalidade, sonda cilíndrica número 3 a uma velocidade de $30 \mathrm{rpm}$, registrando-se os valores de viscosidade aparente em centipoise (cP). 


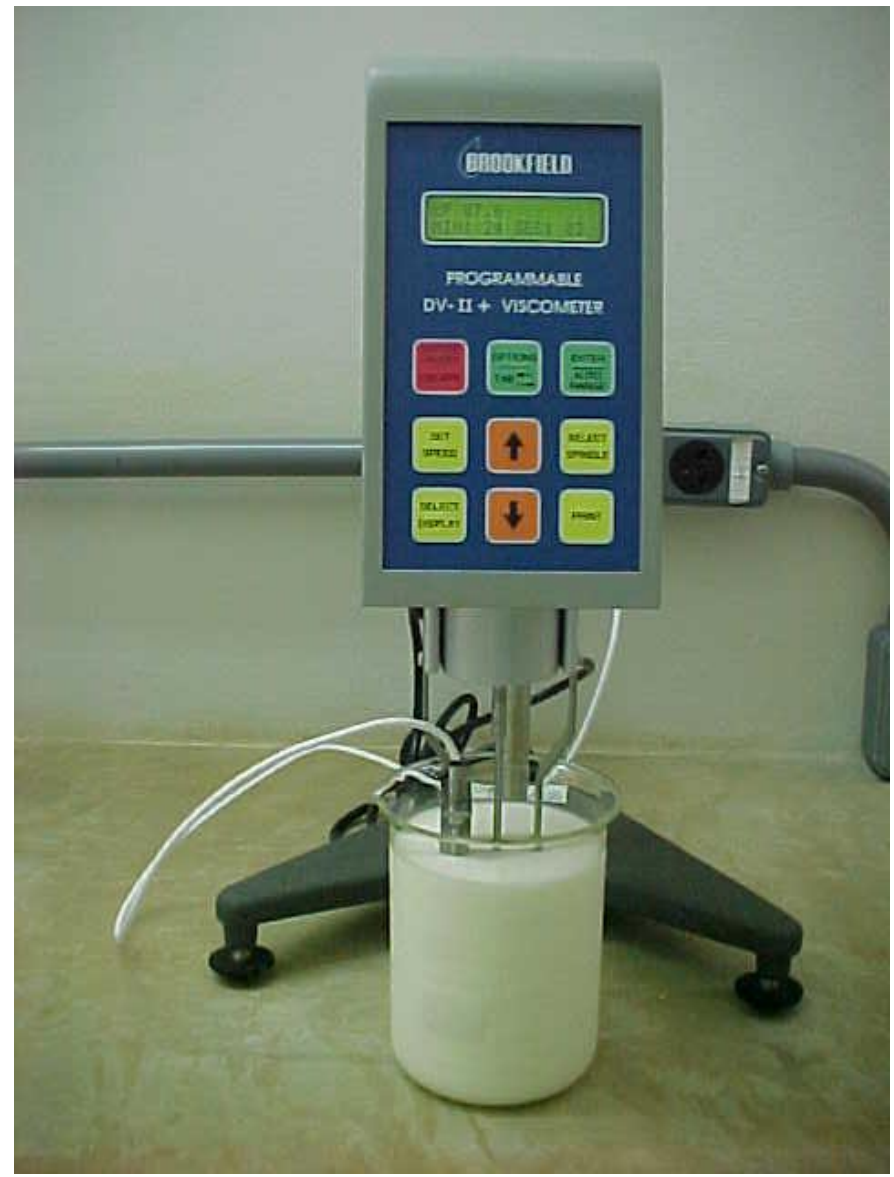

Figura 6. Mensuração da viscosidade aparente do iogurte.

\subsubsection{Avaliação Microbiológica}

Complementarmente, a qualidade microbiológica do iogurte foi avaliada através da determinação do NMP de coliformes a 30 e $45^{\circ} \mathrm{C}$, bem como da contagem de bactérias láticas em agar MRS. A contagem de bactérias láticas foi efetuada através da semeadura de $1 \mathrm{~mL}$ das diluições $10^{-6}$ e $10^{-7}$ em placas, seguida da adição de agar MRS por duas vezes, caracterizando a semeadura em sobrecamada, e incubação a $35^{\circ} \mathrm{C}$ por 48 horas para contagem das colônias (APHA, 1992).

A Figura 7 apresenta, através de um fluxograma, uma síntese das operações para a obtenção do leite, processamento do iogurte, amostragem e respectivas análises realizadas no experimento. 


\subsubsection{Análise estatística}

O delineamento experimental utilizado foi o inteiramente casualizado, considerando-se três tratamentos (baixa, média e alta CCS) e seis repetições. Os resultados obtidos nos exames laboratoriais foram submetidos à análise de variância, de acordo com os procedimentos estabelecidos na General Linear Model do SAS $^{\circledR}$ (SAS Institute, 1992), para a verificação de diferenças estatisticamente significativas nas variáveis estudadas no iogurte produzido a partir dos três tipos de leite. Para a comparação entre as médias, quando aplicável, empregou-se o teste de Tukey, adotando-se, como nível de rejeição, $\alpha=0,05$ (GACULA \& SINGH, 1984). Adicionalmente, os resultados obtidos nas análises de proteólise, lipólise e viscosidade foram utilizados para a determinação do Coeficiente de Correlação de Pearson (r) entre os valores da CCS (transformados em log) e os parâmetros avaliados. O teste t de Student, com aproximação normal, foi utilizado para comparar os valores de correlação a um nível de 5\% de significância (GACULA \& SINGH, 1984). 
Análise Individual dos Animais 1

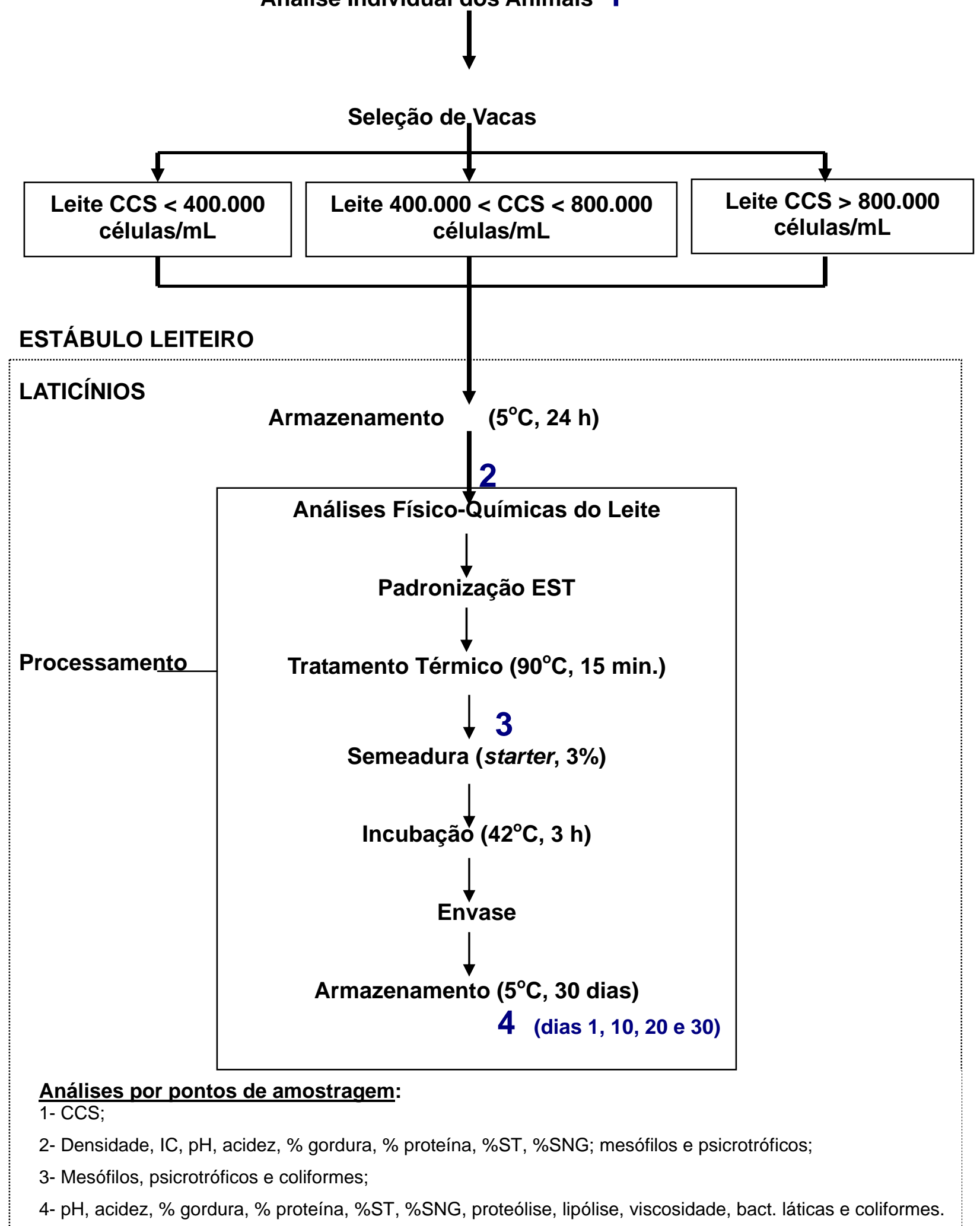

Figura 7: Fluxograma das operações para a obtenção do leite, processamento do iogurte, amostragem e respectivas análises. 


\section{RESULTADOS E DISCUSSÃO}

\subsection{Leites Cru e Pasteurizado}

Os resultados das análises de CCS no leite utilizado em cada repetição, bem como a média dos seis lotes, estão contidos na Tabela 1. As médias foram 147.000 células $/ \mathrm{mL}$ para o leite de baixa CCS, 434.000 células $/ \mathrm{mL}$ para o leite de CCS intermediária, apesar dos valores abaixo de 400.000 nas duas últimas repetições, e 1.943.000 células/mL para o leite de alta contagem.

Tabela 1. Contagem de células somáticas (CCS) no leite utilizado nas repetições de lotes de iogurtes.

\begin{tabular}{|c|c|c|c|c|c|c|c|}
\hline \multirow{2}{*}{$\begin{array}{l}\text { CCS prevista } \\
\text { no leite } \\
\text { (x } 1.000 / \mathrm{mL})\end{array}$} & \multicolumn{6}{|c|}{ CCS obtida nas repetições $(\times 1.000 / \mathrm{mL})$} & \multirow[b]{2}{*}{ Média } \\
\hline & 1 & 2 & 3 & 4 & 5 & 6 & \\
\hline$<400$ & 77 & 162 & 340 & 223 & 51 & 26 & 147 \\
\hline $400-800$ & 424 & 456 & 420 & 713 & 341 & 251 & 434 \\
\hline$>800$ & 2.461 & 1.377 & 3.895 & 1.423 & 1.320 & 1.182 & 1.943 \\
\hline
\end{tabular}

Os resultados apresentados a seguir são referentes às médias de seis lotes de leite destinados à fabricação do iogurte. As Tabelas 2 e 3 demonstram os resultados da análise físico-química do leite cru, cujos valores se encontram de acordo com os padrões e dentro dos limites previstos na legislação brasileira (MINISTÉRIO DA AGRICULTURA, 1980). Os valores de densidade, acidez, pH, 
índice crioscópico, níveis de gordura, ST e SNG semelhantes nos três tipos de leite, o que comprova a eficiência do processo de seleção das vacas quanto à composição físico-química do leite.

Tabela 2. Valores de densidade, acidez, pH e índice crioscópico (IC) do leite $\mathrm{cru}^{1}$, de acordo com a contagem de células somáticas (CCS)*.

\begin{tabular}{ccccc}
\hline $\begin{array}{c}\text { CCS no Leite } \\
(\times \mathbf{1 . 0 0 0 / m L})\end{array}$ & $\begin{array}{c}\text { Densidade } \\
\left(\mathbf{1 5}{ }^{\circ} \mathbf{C}\right)\end{array}$ & Acidez $\left({ }^{\circ} \mathrm{D}\right)$ & $\mathbf{p H}$ & IC $\left({ }^{\circ} \mathrm{H}\right)$ \\
\hline$<\mathbf{4 0 0}$ & $28,65 \pm 0,69$ & $17,00 \pm 1,10$ & $6,65 \pm 0,05$ & $0,544 \pm 0,02$ \\
$\mathbf{4 0 0 - 8 0 0}$ & $29,32 \pm 0,77$ & $17,33 \pm 0,82$ & $6,65 \pm 0,02$ & $0,538 \pm 0,01$ \\
$>\mathbf{8 0 0}$ & $29,70 \pm 1,57$ & $17,50 \pm 0,84$ & $6,62 \pm 0,15$ & $0,542 \pm 0,01$ \\
\hline
\end{tabular}

${ }^{1}$ Resultados relativos à média \pm desvio padrão das amostras de seis lotes, analisadas em duplicata.

* Não foram observadas diferenças significativas $(P>0,05)$ nos resultados apresentados nesta tabela.

Os valores relativos à proteína total do leite cru apresentaram diferenças estatisticamente significativas $(P<0,05)$, com maiores concentrações no leite contendo mais de 800.000 células $/ \mathrm{mL}$, fato que está de acordo com a afirmação de vários autores (MILLER et al, 1983; AULDIST et al, 1995; KLEl et al., 1998; URECH et al., 1998; MARQUES et al., 2002; SOMERS et al., 2003) de que a concentração de proteína total do leite aumenta quando de uma elevada CCS.

Tabela 3. Percentuais de proteína, gordura, sólidos totais (ST) e sólidos não gordurosos (SNG) do leite $\mathrm{cru}^{1}$, de acordo com a contagem de células somáticas (CCS).

\begin{tabular}{ccccc}
\hline $\begin{array}{c}\text { CCS no Leite } \\
(\times 1.000 / \mathrm{mL})\end{array}$ & Proteína (\%) & Gordura (\%) & ST (\%) & SNG (\%) \\
\hline$<\mathbf{4 0 0}$ & $2,90 \pm 0,16 \mathrm{a}^{*}$ & $3,43 \pm 0,36 \mathrm{a}$ & $11,83 \pm 0,56 \mathrm{a}$ & $8,40 \pm 0,23 \mathrm{a}$ \\
$\mathbf{4 0 0 - 8 0 0}$ & $3,00 \pm 0,20 \mathrm{ab}$ & $3,38 \pm 0,24 \mathrm{a}$ & $11,93 \pm 0,47 \mathrm{a}$ & $8,56 \pm 0,24 \mathrm{a}$ \\
$>\mathbf{8 0 0}$ & $3,19 \pm 0,12 \mathrm{~b}$ & $3,38 \pm 0,53 \mathrm{a}$ & $12,03 \pm 0,75 \mathrm{a}$ & $8,65 \pm 0,41 \mathrm{a}$ \\
\hline
\end{tabular}


${ }^{1}$ Resultados relativos à média \pm desvio padrão das amostras de seis lotes, analisadas em duplicata.

* Em uma mesma coluna, médias seguidas de letras desiguais diferem estatisticamente $(P<0,05)$.

Os resultados microbiológicos do leite cru são apresentados na Tabela 4. Os níveis médios de mesófilos e psicrotróficos nos três tipos de leite não apresentaram diferenças significativas, variando de 6,11 a 7,23 log ufc/mL de leite e de 4,39 a 4,92 $\log$ ufc/mL, respectivamente. A semelhança entre os valores dos três tratamentos permitiu considerar o leite como satisfatório para a utilização na produção dos iogurtes.

Tabela 4. Valores de mesófilos e psicrotróficos do leite $\mathrm{cru}^{1}$, de acordo com a contagem de células somáticas (CCS)*.

\begin{tabular}{ccc}
\hline $\begin{array}{c}\text { CCS no Leite } \\
(\times \mathbf{1 . 0 0 0 / m L})\end{array}$ & $\begin{array}{c}\text { Mesófilos } \\
(\log \text { UFC/mL) }\end{array}$ & $\begin{array}{c}\text { Psicrotróficos } \\
(\log \text { UFC/mL) }\end{array}$ \\
\hline $\mathbf{4} \mathbf{4 0 0}$ & $6,11 \pm 0,50$ & $4,39 \pm 1,00$ \\
$\mathbf{4 0 0 - 8 0 0}$ & $6,52 \pm 0,27$ & $4,92 \pm 0,91$ \\
$>\mathbf{8 0 0}$ & $7,23 \pm 1,73$ & $4,37 \pm 0,85$ \\
\hline
\end{tabular}

${ }^{1}$ Resultados relativos ao log da média de amostras de seis lotes, analisadas em duplicata.

* Não foram observadas diferenças significativas $(P>0,05)$ nos resultados apresentados nesta tabela.

A Tabela 5 apresenta os resultados microbiológicos do leite pasteurizado. Estes resultados podem ser considerados satisfatórios para a elaboração dos diferentes tipos de iogurte. Os níveis médios de mesófilos e psicrotróficos variaram de 2,07 a 2,72 log ufc/mL de leite e de 1,13 a 1,71 log ufc/mL, respectivamente. Os valores médios de coliformes totais variaram de 0,93 a 11,46 NMP/mL, e coliformes fecais somente foram detectados somente em dois lotes de leite pasteurizado contendo mais de 800.000 células $/ \mathrm{mL}$, com média de 2,0 NMP/mL. Os valores de 
mesófilos e psicrotróficos foram semelhantes entre os tratamentos, porém os valores de coliformes totais foram progressivamente maiores com o aumento da CCS.

Tabela 5. Valores de mesófilos, psicrotróficos e coliformes totais do leite pasteurizado ${ }^{1}$, de acordo com a contagem de células somáticas (CCS)*.

\begin{tabular}{cccc}
\hline $\begin{array}{c}\text { CCS no Leite }(x \\
\mathbf{1 . 0 0 0 / m L})\end{array}$ & $\begin{array}{c}\text { Mesófilos } \\
(\log \text { ufc/mL) }\end{array}$ & $\begin{array}{c}\text { Psicrotróficos } \\
(\log \text { ufc } / \mathbf{m L})\end{array}$ & $\begin{array}{c}\text { Coliformes Totais } \\
(\mathrm{NMP} / \mathrm{mL})\end{array}$ \\
\hline $\mathbf{4 0 0}$ & $2,07 \pm 0,56$ & $1,13 \pm 0,32$ & $0,93 \pm 1,69$ \\
$\mathbf{4 0 0 - 8 0 0}$ & $2,60 \pm 0,70$ & $1,71 \pm 0,75$ & $8,96 \pm 18,20$ \\
$>\mathbf{8 0 0}$ & $2,72 \pm 1,00$ & $1,15 \pm 0,38$ & $11,46 \pm 12,06$ \\
\hline
\end{tabular}

${ }^{1}$ Resultados relativos à média de amostras de seis lotes, analisadas em duplicata.

* Não foram observadas diferenças significativas $(P>0,05)$ nos resultados apresentados nesta tabela.

\section{2 logurte}

\subsubsection{Avaliação Físico-química}

A Tabela 6 apresenta as médias dos resultados das análises físico-químicas dos iogurtes nos dias 1, 10, 20 e 30 após a fabricação. Não foram observadas diferenças significativas $(P>0,05)$ entre os valores de $\mathrm{pH}$, acidez, gordura, ST e SNG obtidos nos iogurtes produzidos com os três tipos de leite, similarmente ao constatado nas análises físico-químicas do leite cru (Tabelas 2 e 3). Houve aumento na acidez e queda no $\mathrm{pH}$ para todos os lotes ao longo do período de armazenamento. A média de acidez variou de $0,69 \%$ de ácido lático no $1^{\circ}$ dia após a fabricação, para $0,72 \%$ no iogurte de baixa CCS no $30^{\circ}$ dia de armazenamento, e de $0,70 \%$ para $0,76 \%$ no iogurte produzido com leite contendo mais de 800.000 células $/ \mathrm{mL}$. 
Os valores de gordura (Tabela 6) mantiveram-se relativamente estáveis durante o armazenamento, assim como os valores de ST e SNG. A concentração de gordura variou de $3,63 \%$ para $3,58 \%$ e de $3,57 \%$ para $3,63 \%$ nos produtos de baixa e alta CCS, nos dias 1 e 30, respectivamente. Os valores semelhantes de ST no $1^{\circ}$ dia, $13,14 \%, 13,20 \%$ e $13,40 \%$ para os iogurtes de baixa, média e alta CCS, respectivamente, confirmam a eficiência da padronização dos sólidos no leite através da adição de leite em pó desnatado. O SNG não apresentou diferenças, visto que este valor é obtido da diferença entre os parâmetros ST e teor de gordura, os quais foram semelhantes entre os três tipos de iogurte.

ROGERS e MITCHELL (1994), em estudo relacionando CCS e iogurte, concluíram que as médias dos parâmetros $\mathrm{pH}$, gordura e sólidos totais do iogurte produzido com leite de vários níveis de CCS não são significativamente diferentes. OLIVEIRA et al. (2002) também não encontraram diferenças significativas nos parâmetros físico-químicos (acidez, pH, proteína, gordura, ST e SNG) entre os iogurtes produzidos com leite contendo diferentes níveis de CCS.

\subsubsection{Avaliação da Proteólise}

Os resultados das análises referentes à proteína encontram-se na Tabela 7 . Os valores obtidos das concentrações de nitrogênio das amostras foram utilizados para o cálculo da concentração da proteína verdadeira e da caseína. Apesar de no leite cru terem sido observadas concentrações mais elevadas de proteína total, no iogurte os valores obtidos para a concentração de proteína total não apresentaram diferenças significativas $(P>0,05)$ entre os tratamentos, além de se observar uma diminuição na concentração, para os iogurtes dos três tratamentos, com valores de $3,52 \%$ e 3,99 no dia 1 e de $3,33 \%$ e $3,71 \%$ no dia 30 , para os iogurtes de baixa e alta CCS, respectivamente. 
Tabela 6. Valores de acidez, pH, gordura, sólidos totais (ST) e sólidos não gordurosos (SNG) do iogurte ${ }^{1}$, de acordo com a contagem de células somáticas (CCS)*.

\begin{tabular}{|c|c|c|c|c|c|}
\hline $\begin{array}{l}\text { CCS no Leite } \\
(\times 1.000 / \mathrm{mL})\end{array}$ & $\begin{array}{c}\text { Acidez } \\
\text { (\% ác. Lático) }\end{array}$ & $\mathrm{pH}$ & Gordura (\%) & ST (\%) & SNG (\%) \\
\hline \multicolumn{6}{|l|}{ Dia 1 de } \\
\hline \multicolumn{6}{|c|}{ armazenamento } \\
\hline$<400$ & $0,69 \pm 0,11$ & $4,62 \pm 0,11$ & $3,63 \pm 0,35$ & $13,14 \pm 0,61$ & $9,51 \pm 0,86$ \\
\hline $400-800$ & $0,68 \pm 0,05$ & $4,49 \pm 0,06$ & $3,57 \pm 0,25$ & $13,20 \pm 0,41$ & $9,63 \pm 0,64$ \\
\hline$>800$ & $0,70 \pm 0,05$ & $4,54 \pm 0,12$ & $3,57 \pm 0,67$ & $13,40 \pm 0,67$ & $9,83 \pm 0,73$ \\
\hline \multicolumn{6}{|l|}{ Dia 10 de } \\
\hline \multicolumn{6}{|c|}{ armazenamento } \\
\hline$<400$ & $0,71 \pm 0,05$ & $4,37 \pm 0,11$ & $3,62 \pm 0,31$ & $12,75 \pm 0,45$ & $9,14 \pm 0,66$ \\
\hline $400-800$ & $0,74 \pm 0,05$ & $4,27 \pm 0,09$ & $3,60 \pm 0,27$ & $13,20 \pm 0,20$ & $9,60 \pm 0,41$ \\
\hline$>800$ & $0,75 \pm 0,06$ & $4,34 \pm 0,10$ & $3,62 \pm 0,66$ & $13,24 \pm 0,67$ & $9,63 \pm 0,59$ \\
\hline \multicolumn{6}{|l|}{ Dia 20 de } \\
\hline \multicolumn{6}{|c|}{ armazenamento } \\
\hline$<400$ & $0,69 \pm 0,06$ & $4,24 \pm 0,15$ & $3,56 \pm 0,27$ & $12,96 \pm 0,43$ & $9,40 \pm 0,66$ \\
\hline $400-800$ & $0,74 \pm 0,06$ & $4,25 \pm 0,06$ & $3,48 \pm 0,35$ & $13,18 \pm 0,41$ & $9,69 \pm 0,70$ \\
\hline$>800$ & $0,75 \pm 0,03$ & $4,22 \pm 0,14$ & $3,63 \pm 0,68$ & $13,20 \pm 0,77$ & $9,58 \pm 0,87$ \\
\hline \multicolumn{6}{|l|}{ Dia 30 de } \\
\hline \multicolumn{6}{|c|}{ armazenamento } \\
\hline$<400$ & $0,72 \pm 0,06$ & $4,26 \pm 0,14$ & $3,58 \pm 0,36$ & $12,78 \pm 0,31$ & $9,30 \pm 0,41$ \\
\hline $400-800$ & $0,75 \pm 0,05$ & $4,22 \pm 0,21$ & $3,53 \pm 0,26$ & $12,97 \pm 0,31$ & $9,44 \pm 0,42$ \\
\hline$>800$ & $0,76 \pm 0,06$ & $4,25 \pm 0,11$ & $3,63 \pm 0,70$ & $13,53 \pm 0,83$ & $9,90 \pm 0,77$ \\
\hline
\end{tabular}

${ }^{1}$ Resultados expressos em médias \pm desvio padrão, para amostras de seis lotes analisadas em duplicata nos dias $1^{\circ}, 10^{\circ}, 20^{\circ}$ e $30^{\circ}$ após a fabricação.

* Não foram observadas diferenças significativas $(P>0,05)$ nos resultados apresentados nesta tabela. 
Tabela 7. Percentuais de proteína total, proteína verdadeira e caseína do iogurte ${ }^{1}$, de acordo com a contagem de células somáticas (CCS)*.

\begin{tabular}{|c|c|c|c|}
\hline $\begin{array}{l}\text { CCS no Leite } \\
(\times 1.000 / \mathrm{mL})\end{array}$ & $\begin{array}{l}\text { Proteína Total } \\
\qquad(\%)\end{array}$ & $\begin{array}{c}\text { Proteína Verdadeira } \\
\qquad(\%)\end{array}$ & $\begin{array}{c}\text { Caseína } \\
(\%)\end{array}$ \\
\hline \multicolumn{4}{|l|}{ Dia 1 de } \\
\hline \multicolumn{4}{|l|}{ armazenamento } \\
\hline$<400$ & $3,52 \pm 0,53$ & $3,24 \pm 0,51$ & $3,10 \pm 0,48$ \\
\hline $400-800$ & $3,74 \pm 0,38$ & $3,47 \pm 0,38$ & $3,31 \pm 0,34$ \\
\hline$>800$ & $3,99 \pm 0,30$ & $3,70 \pm 0,30$ & $3,53 \pm 0,18$ \\
\hline \multicolumn{4}{|l|}{ Dia 10 de } \\
\hline \multicolumn{4}{|l|}{ armazenamento } \\
\hline$<400$ & $3,60 \pm 0,39$ & $3,32 \pm 0,37$ & $3,19 \pm 0,38$ \\
\hline $400-800$ & $3,59 \pm 0,44$ & $3,31 \pm 0,42$ & $3,18 \pm 0,40$ \\
\hline$>800$ & $4,03 \pm 0,41$ & $3,73 \pm 0,42$ & $3,56 \pm 0,33$ \\
\hline \multicolumn{4}{|l|}{ Dia 20 de } \\
\hline \multicolumn{4}{|l|}{ armazenamento } \\
\hline$<400$ & $3,51 \pm 0,38$ & $3,23 \pm 0,36$ & $3,10 \pm 0,36$ \\
\hline $400-800$ & $3,55 \pm 0,24$ & $3,23 \pm 0,18$ & $3,11 \pm 0,17$ \\
\hline$>800$ & $3,72 \pm 0,16$ & $3,43 \pm 0,17$ & $3,28 \pm 0,15$ \\
\hline \multicolumn{4}{|l|}{ Dia 30 de } \\
\hline \multicolumn{4}{|l|}{ armazenamento } \\
\hline$<400$ & $3,33 \pm 0,25$ & $3,04 \pm 0,22$ & $3,02 \pm 0,13$ \\
\hline $400-800$ & $3,42 \pm 0,15$ & $3,12 \pm 0,13$ & $3,17 \pm 0,16$ \\
\hline$>800$ & $3,71 \pm 0,19$ & $3,42 \pm 0,15$ & $3,26 \pm 0,18$ \\
\hline
\end{tabular}

${ }^{1}$ Resultados expressos em médias \pm desvio padrão, para amostras de seis lotes, analisadas em duplicata nos dias $1^{\circ}, 10^{\circ}, 20^{\circ}$ e $30^{\circ}$ após a fabricação.

* Não foram observadas diferenças significativas $(P>0,05)$ nos resultados apresentados nesta tabela.

Os resultados referentes aos teores de proteína verdadeira e caseína também não apresentaram diferenças significativas $(P>0,05)$, observando-se uma 
diminuição dos valores ao longo do período de armazenamento. Estes resultados estão de acordo com os obtidos por VERDI et al. (1987), em que as porcentagens de proteína verdadeira e caseína no leite não foram afetadas pelo nível de CCS.

A relação caseína:proteína total manteve-se constante para os três tratamentos em todos os dias de análises, contrariando os resultados obtidos por HAENLEIN et al. (1972), nos quais amostras de leite com maiores níveis de CCS apresentaram menores valores para caseína total e menor relação caseína:proteína total. SCHULTZ (1977) e BALLOU et al. (1995) também afirmam que no leite com alta CCS há menores concentrações de caseína em relação ao leite com baixas contagens.

A partir dos valores das concentrações de proteína verdadeira e de caseína obteve-se o índice de proteólise no iogurte, apresentado na Tabela 8. Adicionalmente, foram determinadas as relações entre as concentrações de NNC e NNP e o valor de NT (Tabela 8). Os valores obtidos para o índice de proteólise foram muito semelhantes entre os tipos de iogurte e muito constantes no decorrer do armazenamento. Os valores da relação NNC/NT e NNP/NT também não apresentaram diferenças significativas, e não foram observadas correlações significativas (Tabela 9) entre a CCS e os parâmetros índice de proteólise, relação NNC/NT e NNP/NT, confirmando que a proteólise nos iogurtes foi semelhante e não se observando, portanto, qualquer efeito adicional da concentração de células somáticas sobre este parâmetro.

OKELLO-UMA e MARSHALL (1986) constataram que altas CCS no leite não ocasionam diferenças significativas no crescimento dos microrganismos da cultura starter utilizada para a fabricação de iogurtes, não alterando, portanto, a quantidade de proteólise no produto que poderia ser atribuída à atividade da cultura. No entanto, segundo TAMIME e DEETH (1980), altos níveis de AGL no leite podem prejudicar a proteólise originada da atividade da cultura starter. 
Tabela 8. Valores obtidos no cálculo do índice de proteólise e relações NNC I NT e NNP / NT do iogurte ${ }^{1}$, de acordo com a contagem de células somáticas (CCS)*.

\begin{tabular}{|c|c|c|c|}
\hline $\begin{array}{l}\text { CCS no Leite } \\
(\times 1.000 / \mathrm{mL})\end{array}$ & Índice de Proteólise & NNC / NT & NNP / NT \\
\hline
\end{tabular}

\section{Dia 1 de}

armazenamento

$\begin{array}{clll}<400 & 0,96 \pm 0,01 & 0,12 \pm 0,02 & 0,08 \pm 0,01 \\ 400-800 & 0,96 \pm 0,01 & 0,11 \pm 0,02 & 0,07 \pm 0,01 \\ >800 & 0,95 \pm 0,03 & 0,12 \pm 0,02 & 0,07 \pm 0,01\end{array}$

\section{Dia 10 de}

armazenamento

$\begin{array}{cccc}<400 & 0,96 \pm 0,01 & 0,12 \pm 0,02 & 0,08 \pm 0,01 \\ 400-800 & 0,96 \pm 0,01 & 0,12 \pm 0,01 & 0,08 \pm 0,01 \\ >800 & 0,96 \pm 0,02 & 0,12 \pm 0,02 & 0,08 \pm 0,02\end{array}$

\section{Dia 20 de}

armazenamento

$\begin{array}{clll}<400 & 0,96 \pm 0,01 & 0,12 \pm 0,01 & 0,08 \pm 0,01 \\ 400-800 & 0,96 \pm 0,01 & 0,11 \pm 0,01 & 0,08 \pm 0,01 \\ >800 & 0,96 \pm 0,02 & 0,12 \pm 0,02 & 0,08 \pm 0,01\end{array}$

Dia 30 de

armazenamento

$\begin{array}{cccc}<400 & 0,96 \pm 0,01 & 0,12 \pm 0,01 & 0,08 \pm 0,01 \\ 400-800 & 0,96 \pm 0,01 & 0,12 \pm 0,02 & 0,08 \pm 0,01 \\ >800 & 0,95 \pm 0,01 & 0,13 \pm 0,02 & 0,08 \pm 0,01\end{array}$

${ }^{1}$ Resultados expressos em médias \pm desvio padrão, para amostras de seis lotes analisadas em duplicata nos dias $1^{\circ}, 10^{\circ}, 20^{\circ}$ e $30^{\circ}$ após a fabricação.

* Não foram observadas diferenças significativas $(P>0,05)$ nos resultados apresentados nesta tabela.

NNC: Nitrogênio não caseinoso; NNP: Nitrogênio não protéico; NT: Nitrogênio total. 
Tabela 9. Correlação ( $r$ ) entre a contagem de células somáticas (log) e o índice de proteólise e as razões NNC I NT e NNP I NT do iogurte*.

\begin{tabular}{cccc}
\hline Dia de & \multicolumn{3}{c}{$r$} \\
\cline { 2 - 4 } Armazenamento & Índice de Proteólise & NNC / NT & NNP/ NT \\
\hline Dia 1 & $-0,38$ & $-0,07$ & $-0,45$ \\
Dia 10 & $-0,17$ & 0,04 & $-0,16$ \\
Dia 20 & $-0,01$ & $-0,14$ & $-0,05$ \\
Dia 30 & $-0,24$ & 0,04 & $-0,33$ \\
\hline
\end{tabular}

* Não foram observadas correlações significativas $(P>0,05)$ nos resultados apresentados nesta tabela.

NNC: Nitrogênio não caseinoso; NNP: Nitrogênio não protéico; NT: Nitrogênio total.

\subsubsection{Avaliação da Lipólise}

A Figura 8 ilustra a curva de calibração obtida na análise de AGL, construída com ácido palmítico e com resultados expressos em meq/L. A respectiva equação de regressão, que apresentou o coeficiente de determinação $\left(R^{2}\right)$ de 0,9874 , foi utilizada para calcular as concentrações de AGL nas amostras de iogurte.

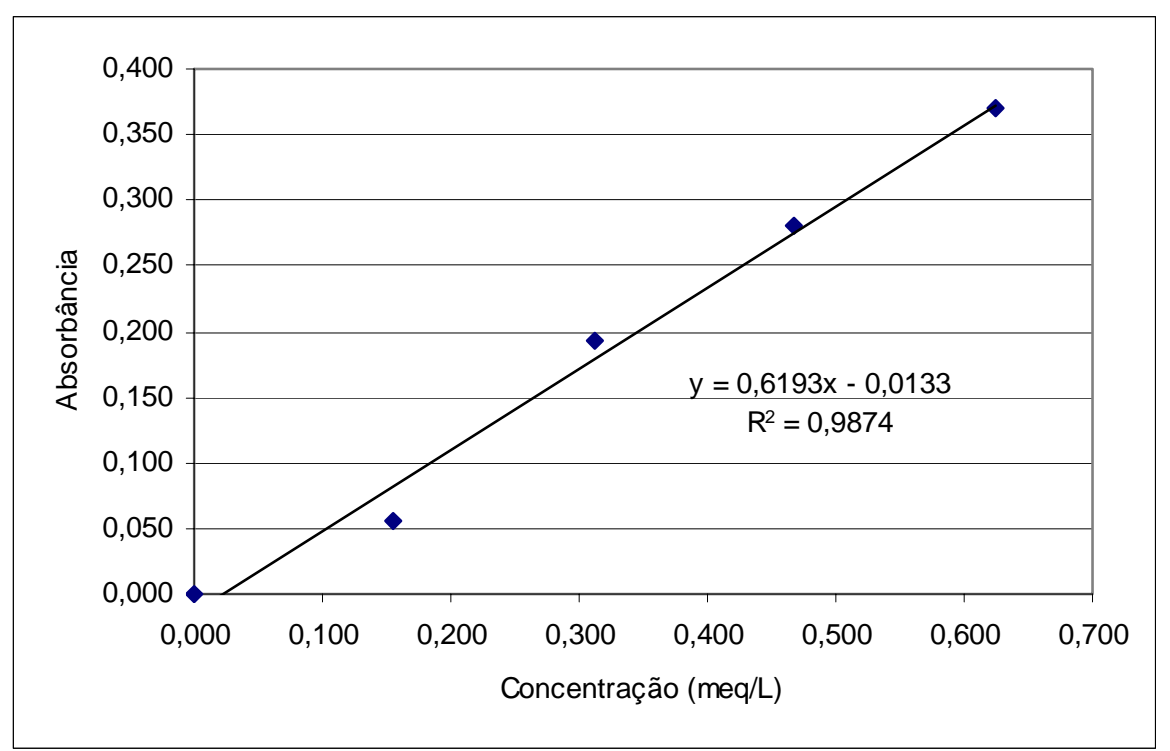

Figura 8. Curva de calibração construída com o padrão de ácido palmítico, obtida na análise de ácidos graxos livres nos iogurtes. 
A Tabela 10 apresenta os resultados referentes às concentrações de AGL no iogurte. Pode-se observar que as concentrações de AGL do iogurte produzido com leite contendo alta CCS foram sempre maiores que as concentrações dos demais iogurtes, e significativamente maiores $(P<0,05)$ nos dias 1 e 30 após a fabricação. A Figura 9 ilustra o incremento nas concentrações de AGL, para todos os tipos de iogurte, até o $30^{\circ}$ dia de armazenamento.

Tabela 10. Concentrações de ácidos graxos livres (AGL) do iogurte ${ }^{1}$, de acordo com a contagem de células somáticas (CCS).

\begin{tabular}{ccccc}
\hline & \multicolumn{4}{c}{ Concentração de AGL (meq/L) ${ }^{2}$} \\
\cline { 2 - 5 } CCS no Leite & $\begin{array}{c}\text { Dia 1 de } \\
\text { (x 1.000/mL) }\end{array}$ & $\begin{array}{c}\text { Dia 10 de } \\
\text { armazenamento }\end{array}$ & $\begin{array}{c}\text { Dia 20 de } \\
\text { armazenamento }\end{array}$ & $\begin{array}{c}\text { Dia 30 de } \\
\text { armazenamento }\end{array}$ \\
\hline$<400$ & $0,18 \pm 0,08 \mathrm{a}^{*}$ & $0,22 \pm 0,10 \mathrm{a}$ & $0,30 \pm 0,19 \mathrm{a}$ & $0,30 \pm 0,01 \mathrm{a}$ \\
$400-800$ & $0,27 \pm 0,11 \mathrm{ab}$ & $0,31 \pm 0,16 \mathrm{a}$ & $0,43 \pm 0,30 \mathrm{a}$ & $0,46 \pm 0,12 \mathrm{ab}$ \\
$>800$ & $0,42 \pm 0,15 \mathrm{~b}$ & $0,31 \pm 0,10 \mathrm{a}$ & $0,52 \pm 0,25 \mathrm{a}$ & $0,56 \pm 0,19 \mathrm{~b}$ \\
\hline
\end{tabular}

${ }^{1}$ Resultados expressos em médias \pm desvio padrão, para amostras de seis lotes analisadas em duplicata nos dias $1^{\circ}, 10^{\circ}, 20^{\circ}$ e $30^{\circ}$ após a fabricação.

${ }^{2}$ Expresso em ácido palmítico.

* Em uma mesma coluna, médias seguidas de letras desiguais diferem estatisticamente $(P<0,05)$.

Os resultados obtidos no presente trabalho sugerem uma maior atividade lipolítica associada à CCS durante o armazenamento do iogurte. Esta observação está de acordo com a afirmação de alguns autores de que a concentração de AGL no leite de vacas com mastite é mais alta (TALLAMY \& RANDOLPH, 1969; RANDOLPH \& ERWIN, 1974), havendo correlação com a CCS (SALIH \& ANDERSON, 1979; BACHMAN et al., 1988). DOWNEY (1980) reportou que contagens acima de $10^{6}$ ou $10^{7}$ ufc/mL são requeridas no leite para que apenas as enzimas microbianas causem significativa lipólise e, como nos leites pasteurizados utilizados para a produção do iogurte as contagens foram semelhantes entre si e 
inferiores a estes valores, pode-se concluir que a atividade lipolitica observada teve origem, em grande parte, nas enzimas lipolíticas intrínsecas do leite. Estas enzimas podem ser de origem das células somáticas ou a LLP, que, segundo AZZARA e DIMICK (1985a), tem atividade aumentada no leite mastítico.

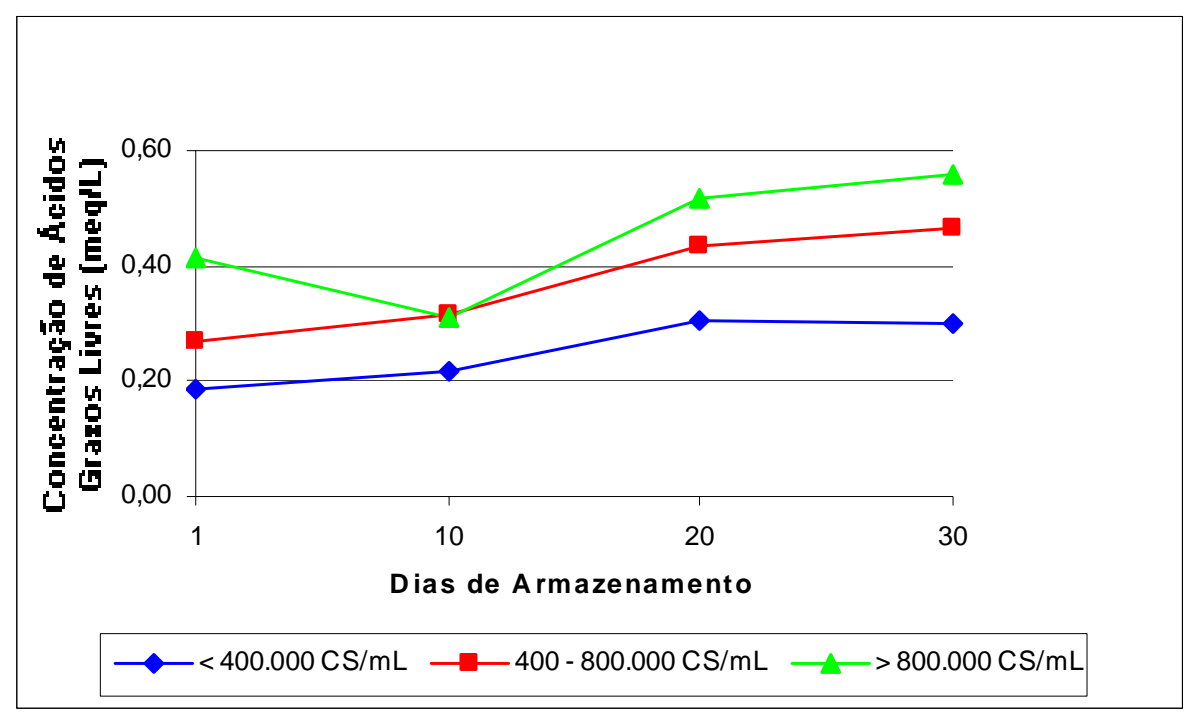

Figura 9. Evolução das concentrações de ácidos graxos livres (expresso em ácido palmítico) dos iogurtes nos dias 1, 10, 20 e 30 após a fabricação.

A correlação entre os valores de $\log$ CCS e concentração de AGL nos iogurtes encontra-se na Tabela 11. Observou-se uma correlação positiva significativa $(P<0,05)$ entre estas variáveis nos dias 1 e 30 de armazenamento. TAMIME e DEETH (1980) afirmam que, apesar de a lipólise no iogurte ocorrer em pequeno grau, esta pode ser atribuída às enzimas lipolíticas das bactérias starter, sendo a lipase natural do leite completamente inativada pela pasteurização. Assim, considerando que no presente experimento utilizou-se a mesma cultura starter para a produção dos iogurtes de todos os tratamentos, em quantidades idênticas, conclui-se que a maior lipólise observada nos iogurtes produzidos com leite contendo alta CCS durante o armazenamento foi devida exclusivamente à CCS no 
leite original. A relação entre os valores de log CCS e de AGL nos iogurtes analisados nos dias 1 e 30 de armazenamento pode ser observada nas Figuras 10 e 11, respectivamente.

Tabela 11. Correlação ( $r$ ) entre a contagem de células somáticas (log) e a concentração de ácidos graxos livres do iogurte.

\begin{tabular}{ccc}
\hline $\begin{array}{c}\text { Dia de } \\
\text { armazenamento }\end{array}$ & $r$ & $P$ \\
\hline Dia 1 & 0,80 & 0,001 \\
Dia 10 & 0,20 & 0,40 \\
Dia 20 & 0,39 & 0,20 \\
Dia 30 & 0,67 & 0,02 \\
\hline
\end{tabular}

$r$ = Coeficiente de correlação; $P$ = Nível de significância.

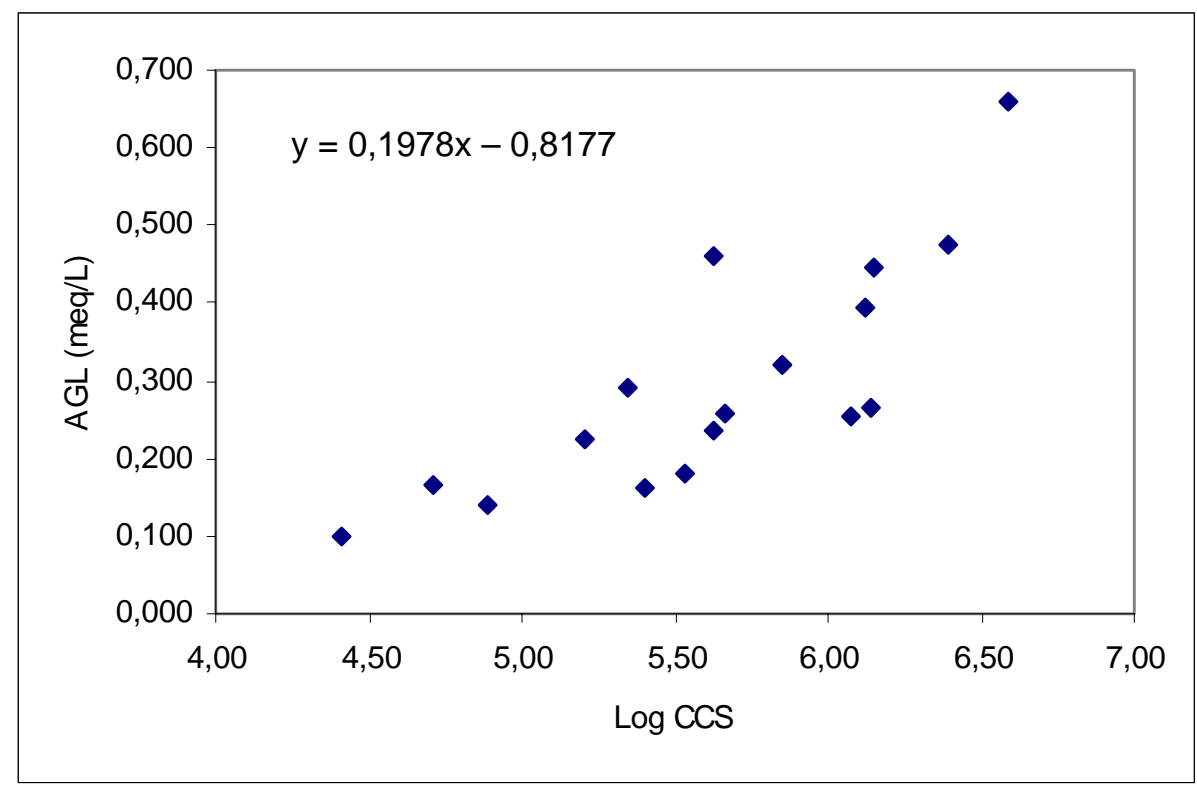

Figura 10. Relação entre a contagem de células somáticas (log CCS) e a concentração de ácidos graxos livres (AGL - expresso em ácido palmítico) no iogurte no $1^{\circ}$ dia após a fabricação. 


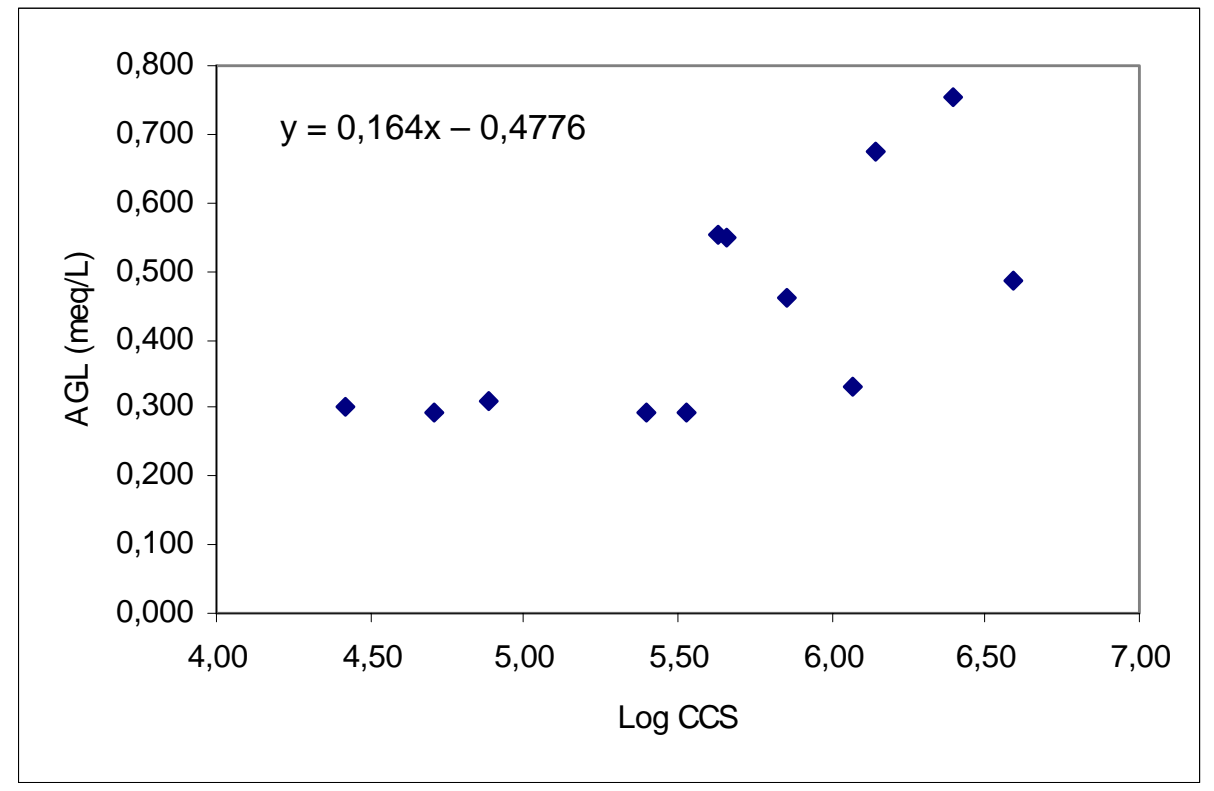

Figura 11. Relação entre a contagem de células somáticas (log CCS) e a concentração de ácidos graxos livres (AGL - expresso em ácido palmítico) no iogurte no $30^{\circ}$ dia após a fabricação.

A maior concentração de AGL encontrada no iogurte produzido com leite contendo altos níveis de CCS pode ser uma possível explicação para as menores notas de sabor atribuídas ao iogurte com mais de 800.000 células $/ \mathrm{mL}$ no estudo de OLIVEIRA et al. (2002), visto que os AGL, sobretudo os de cadeia curta, são responsáveis por defeitos de sabor no leite (DOWNEY, 1980; DEETH, 1993; MUIR, 1996).

\subsubsection{Avaliação da Viscosidade Aparente}

As Figuras 12, 13, 14 e 15 ilustram as curvas de viscosidade aparente média dos iogurtes nos dias 1, 10, 20 e 30 após a fabricação, respectivamente. No $1^{\circ}$ dia, os valores foram próximos entre os três tipos de iogurte, porém, durante o armazenamento, observou-se uma viscosidade proporcionalmente maior dos produtos elaborados com leite contendo média e alta CCS. 


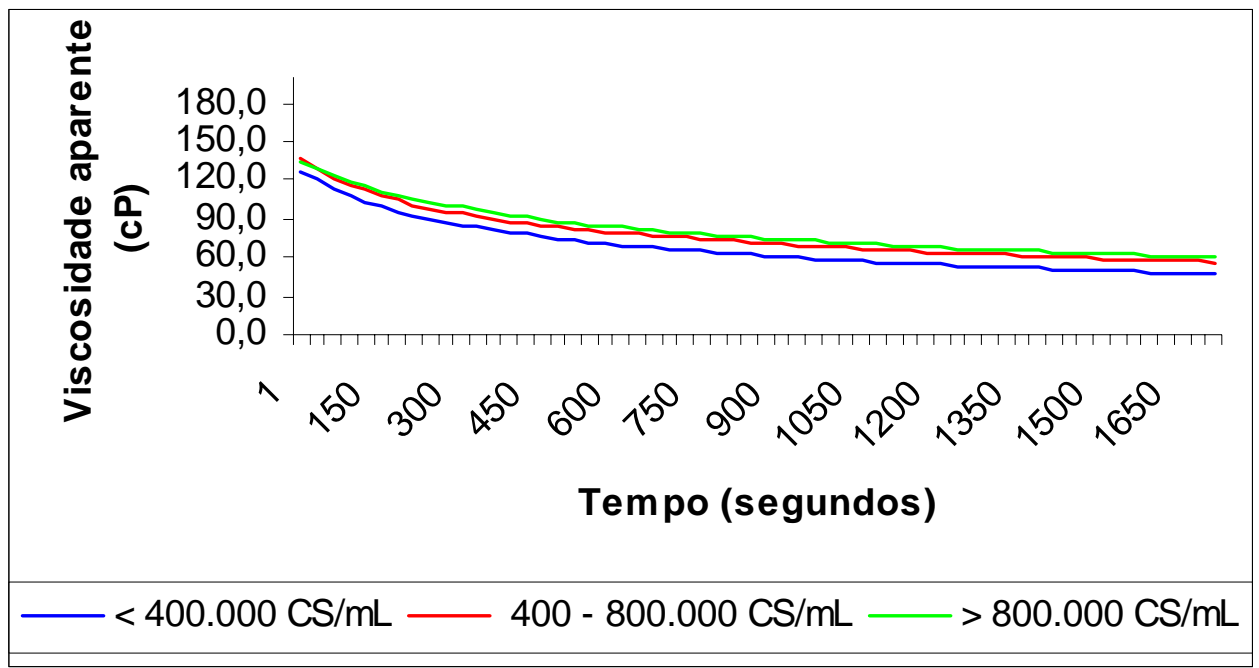

Figura 12. Curva de viscosidade aparente dos iogurtes no dia 1 após fabricação.

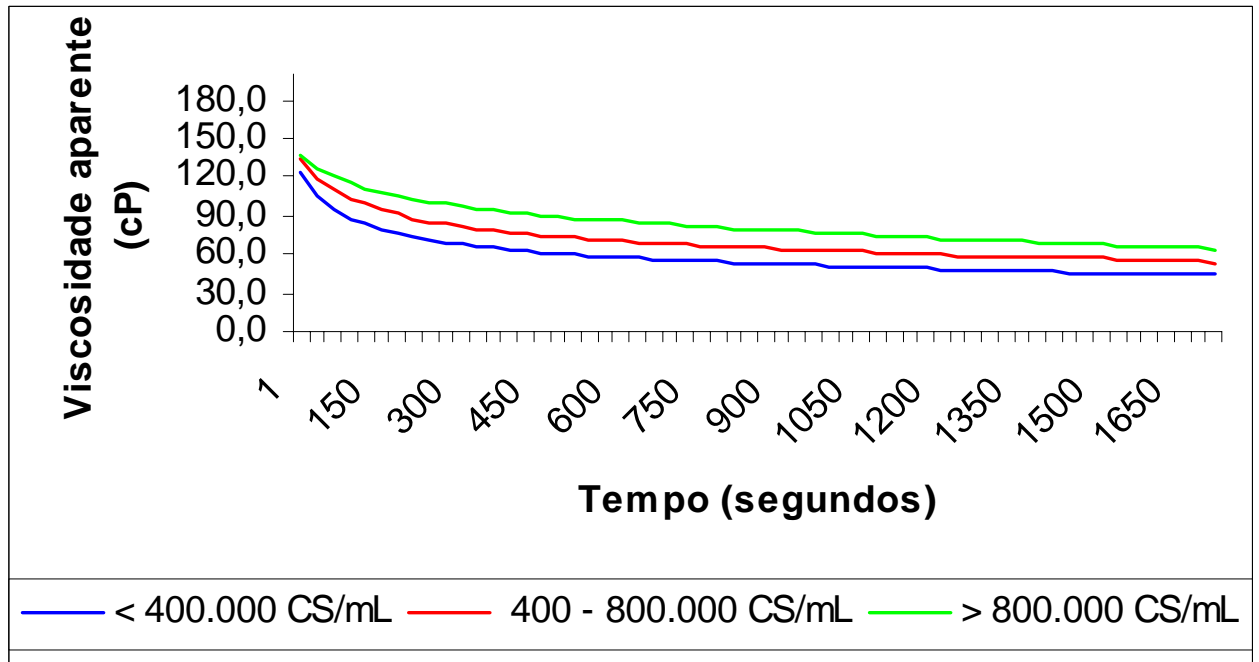

Figura 13. Curva de viscosidade aparente dos iogurtes no dia 10 após fabricação. 


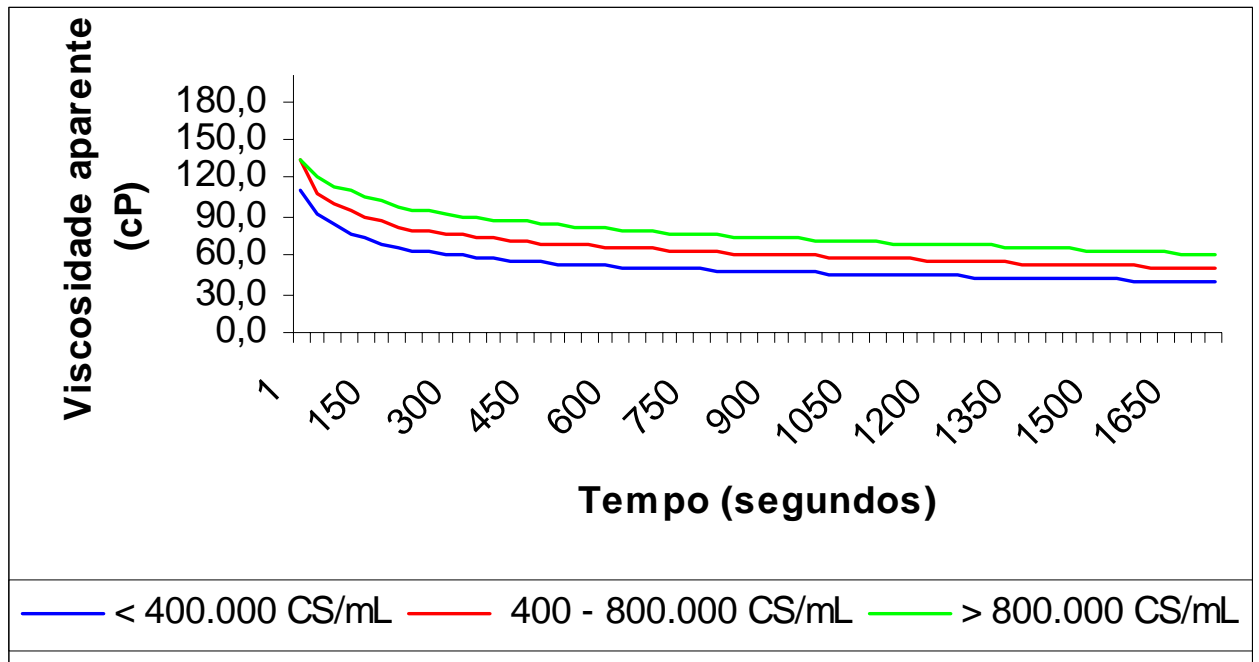

Figura 14. Curva de viscosidade aparente dos iogurtes no dia 20 após fabricação.

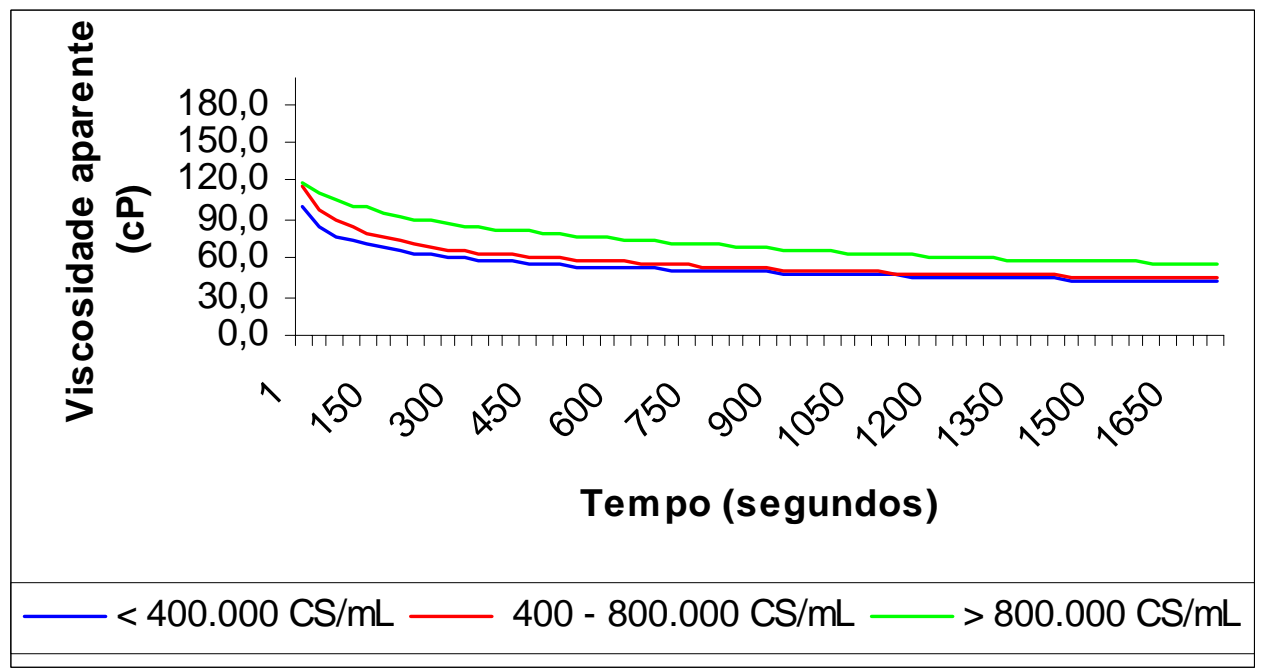

Figura 15. Curva de viscosidade aparente dos iogurtes no dia 30 após fabricação.

As médias obtidas nas análises de viscosidade aparente dos iogurtes estão contidas na Tabela 12. Observou-se que o iogurte produzido com leite contendo altos níveis de CCS apresentou médias de viscosidade aparente significativamente 
maiores $(P<0,05)$ em relação ao iogurte de baixa $\operatorname{CCS}$ no $10^{\circ}$ dia de armazenamento, bem como no $20^{\circ}$ e no $30^{\circ}$ dia de armazenamento. A média de viscosidade aparente do iogurte contendo até 400.000 células $/ \mathrm{mL}$ decresceu no decorrer dos 30 dias de armazenamento, assim como, em menor escala, para o iogurte de CCS intermediária. No entanto, observou-se um comportamento diferente para a média de viscosidade aparente do iogurte contendo mais de 800.000 células $/ \mathrm{mL}$ em relação aos demais produtos, havendo um ligeiro aumento no $10^{\circ}$ dia de armazenamento, com posterior queda no $20^{\circ}$ dia, e mantendo-se constante no $30^{\circ}$ dia (Figura 16). Na Tabela 13 pode-se observar que houve correlação positiva entre a CCS e a média da viscosidade aparente dos iogurtes, sendo que esta correlação foi significativa $(P<0,05)$ nos dias 10 e 20 após a fabricação.

Tabela 12. Viscosidade aparente do iogurte ${ }^{1}$, de acordo com a contagem de células somáticas (CCS).

\begin{tabular}{ccccc}
\hline & \multicolumn{4}{c}{ Viscosidade Aparente (cP) } \\
\cline { 2 - 5 } CCS no Leite & $\begin{array}{c}\text { Dia 1 de } \\
\text { (x 1.000/mL) }\end{array}$ & $\begin{array}{c}\text { Dia 10 de } \\
\text { armazenamento }\end{array}$ & $\begin{array}{c}\text { Dia 20 de } \\
\text { armazenamento }\end{array}$ & $\begin{array}{c}\text { Dia 30 de } \\
\text { armazenamento }\end{array}$ \\
\hline$<400$ & $68,00 \pm 12,38 \mathrm{a}^{*}$ & $58,16 \pm 10,41 \mathrm{a}$ & $51,76 \pm 14,25 \mathrm{a}$ & $53,66 \pm 16,80 \mathrm{a}$ \\
$400-800$ & $77,24 \pm 10,28 \mathrm{a}$ & $70,29 \pm 11,69 \mathrm{ab}$ & $65,53 \pm 11,66 \mathrm{ab}$ & $62,68 \pm 17,25 \mathrm{ab}$ \\
$>800$ & $80,93 \pm 13,47 \mathrm{a}$ & $83,50 \pm 8,30 \mathrm{~b}$ & $78,52 \pm 14,69 \mathrm{~b}$ & $78,73 \pm 12,21 \mathrm{~b}$ \\
\hline
\end{tabular}

${ }^{1}$ Resultados expressos em médias \pm desvio padrão, para amostras de seis lotes analisadas em duplicata nos dias $1^{\circ}, 10^{\circ}, 20^{\circ}$ e $30^{\circ}$ após a fabricação.

* Em uma mesma coluna, médias seguidas de letras desiguais diferem estatisticamente $(P<0,05)$. 


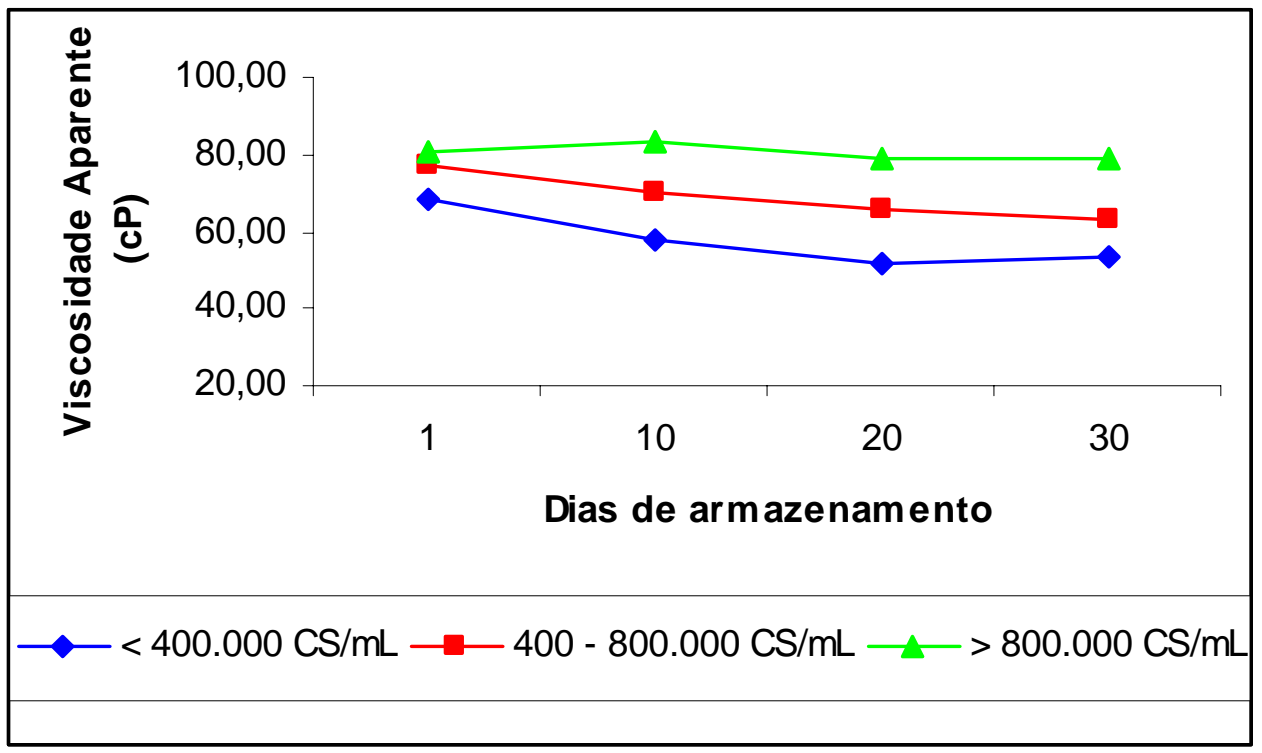

Figura 16. Evolução das médias de viscosidade aparente dos iogurtes nos dias 1, 10, 20 e 30 após a fabricação.

Tabela 13. Correlação ( $r$ ) entre a contagem de células somáticas (log) e a viscosidade aparente do iogurte.

\begin{tabular}{ccc}
\hline $\begin{array}{c}\text { Dia de } \\
\text { armazenamento }\end{array}$ & $r$ & $P$ \\
\hline Dia 1 & 0,22 & 0,40 \\
Dia 10 & 0,54 & 0,04 \\
Dia 20 & 0,54 & 0,04 \\
Dia 30 & 0,41 & 0,10 \\
\hline
\end{tabular}

$r$ = Coeficiente de correlação; $P$ = Nível de significância.

Os resultados obtidos neste estudo contrariam os obtidos por ROGERS e MITCHELL (1994), que observaram uma correlação significativa negativa ( $r=$ 0,61 ) entre a CCS e a viscosidade do iogurte, porém este fato foi observado em apenas uma das duas propriedades nas quais o estudo foi conduzido. OLIVEIRA et al. (2002) afirmaram que a consistência do iogurte batido contendo alta CCS, através de avaliação sensorial por painel treinado, recebeu menores notas a partir do $10^{\circ}$ dia de armazenamento em relação ao produto contendo baixas contagens, e 
PENNA et al. (1996), reportou que as medidas instrumentais e sensoriais se correlacionam entre si.

CHENG et al. (2002) reportaram uma correlação positiva entre a viscosidade do iogurte batido e a concentração de caseína. De fato, as concentrações de caseína no iogurte produzido com leite de alta CCS foram maiores do que as do produto de baixa contagem, porém as diferenças observadas não foram estatisticamente significativas, como ocorreu em relação à viscosidade.

CHRISTEN e NDOMBA (1991), em estudo com leite UHT, concluíram que quanto maior a CCS, menor a viscosidade do produto. Entretanto KOHLMANN et al. (1991) reportaram que a adição de plasmina no leite UHT causa formação de gel a partir de 90 dias de armazenamento, e esta geleificação é acompanhada de aumento na viscosidade aparente. Como as células somáticas estão relacionadas com a conversão de plasminogênio em plasmina no leite (VERDI \& BARBANO, 1991b), sugere-se que a maior viscosidade aparente observada no iogurte contendo mais de 800.000 células/mL é conseqüência de uma possível geleificação do produto.

GASSEM e FRANK (1990) afirmaram que a plasmina pode afetar negativamente a qualidade do iogurte. Em outro trabalho, porém, estes mesmos autores (GASSEM e FRANK, 1991) observaram que o iogurte produzido com leite previamente tratado com proteases microbianas apresentou maior viscosidade aparente, enquanto que o iogurte produzido com leite adicionado de plasmina apresentou menor viscosidade aparente.

\subsubsection{Avaliação Microbiológica}

A Tabela 14 apresenta os resultados microbiológicos obtidos no iogurte. Os resultados de contagem de bactérias láticas foram semelhantes entre os diferentes 
tipos de iogurte ao longo do armazenamento (Figura 17), não evidenciando nenhum efeito aparente das células somáticas sobre este parâmetro, como também relataram OKELLO-UMA e MARSHALL (1986).

Tabela 14. Contagem de bactérias lácticas e coliformes totais do iogurte ${ }^{1}$, de acordo com a contagem de células somáticas (CCS).

\begin{tabular}{ccc}
\hline CCS no Leite & Bactérias Láticas & Coliformes Totais (NMP/mL) \\
$(\times 1.000 / \mathrm{mL})$ & $(\log$ ufc $/ \mathrm{mL})$ & \\
\hline
\end{tabular}

Dia 1 de armazenamento

$\begin{array}{cll}<400 & 6,20 \pm 0,95 & 2,04 \pm 0,84 \\ 400-800 & 6,35 \pm 1,15 & 1,95 \pm 1,06 \\ >800 & 6,85 \pm 0,51 & 2,03 \pm 1,05\end{array}$

Dia 10 de armazenamento

$\begin{array}{cll}<400 & 6,51 \pm 1,64 & 0,49 \pm 0,83 \\ 400-800 & 6,88 \pm 1,49 & 0,47 \pm 0,49 \\ >800 & 6,72 \pm 0,89 & 2,22 \pm 2,07\end{array}$

Dia 20 de armazenamento

$\begin{array}{cll}<400 & 6,03 \pm 1,59 & 0 \\ 400-800 & 6,55 \pm 1,37 & 0 \\ >800 & 6,52 \pm 0,01 & 0\end{array}$

Dia 30 de armazenamento

$\begin{array}{cll}<400 & 6,36 \pm 1,43 & 0 \\ 400-800 & 7,07 \pm 0,73 & 0 \\ >800 & 6,90 \pm 0,51 & 0\end{array}$

1 Resultados expressam a média de amostras de seis lotes (em duplicata) analisadas nos dias $1^{\circ}, 10^{\circ}, 20^{\circ}$ e $30^{\circ}$ após a fabricação.

* Não foram observadas diferenças significativas $(P>0,05)$ nos resultados apresentados nesta tabela.

A presença de coliformes totais foi constatada em alguns lotes nos dias 1 e 10 de armazenamento, assim como coliformes fecais. Porém, estes foram encontrados em níveis bem abaixo do limite estabelecido pela legislação brasileira - 10 NMP/mL (MINISTÉRIO DA SAÚDE, 2001). Observou-se que os coliformes totais não foram mais detectados a partir do $20^{\circ}$ dia de armazenamento, e os 
coliformes fecais, nos iogurtes contendo baixa e média CCS, a partir do $10^{\circ}$ dia de armazenamento, e a partir do $20^{\circ}$ dia para o iogurte com alta CCS, devido, provavelmente, à competição com as bactérias do cultivo lácteo.

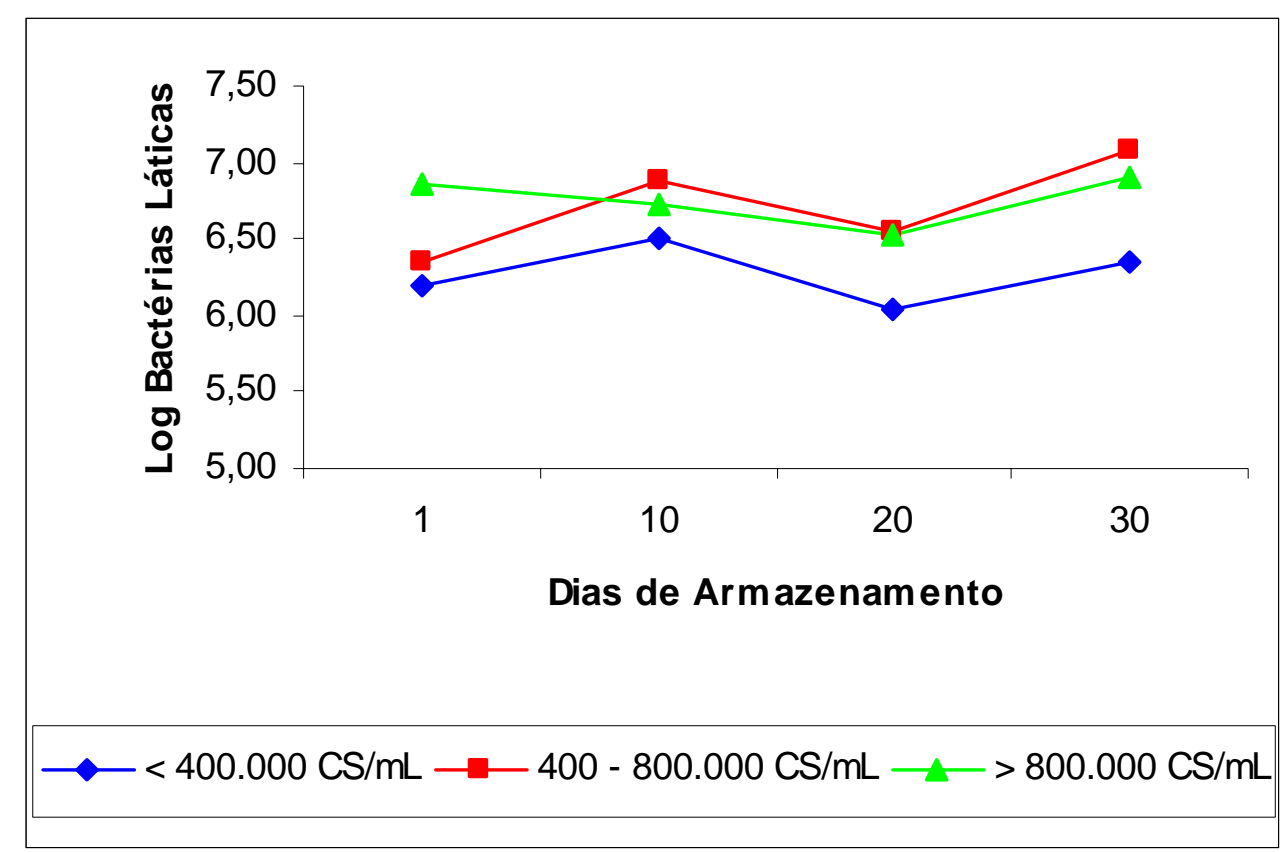

Figura 17. Evolução da contagem de bactérias lácticas dos iogurtes nos dias 1, 10, 20 e 30 a fabricação.

Os resultados apresentados neste estudo indicam um efeito deletério das células somáticas sobre a qualidade do iogurte natural batido, o que comprova a necessidade de regras que limitem sua quantidade no leite destinado à fabricação de produtos lácteos. O cumprimento das novas diretrizes a serem adotadas no país a partir de 2005 deve ser incentivado pelas indústrias de laticínios através de programas de pagamento pela qualidade do leite, incluindo o parâmetro CCS, a exemplo do que vem ocorrendo nos países que já respeitam os limites para a CCS. 


\section{CONCLUSÕES}

De acordo com os resultados obtidos no presente estudo, e considerando os objetivos propostos, pode-se concluir que:

1. O iogurte natural batido produzido com leite contendo mais de 800.000 células somáticas/mL é mais suscetível à lipólise em relação àquele produzido com leite contendo baixos níveis de CCS;

2. A CCS é correlacionada positivamente com a concentração de ácidos graxos livres presentes no iogurte natural batido;

3. A viscosidade aparente do iogurte natural batido produzido com leite contendo mais de 800.000 células somáticas $/ \mathrm{mL}$ apresenta maiores valores, a partir do $10^{\circ}$ dia de armazenamento, quando comparado ao produto de baixa CCS, sugerindo uma possível geleificação do produto associada à CCS;

4. A CCS é correlacionada positivamente à viscosidade aparente do iogurte natural batido no $10^{\circ}$ e $20^{\circ}$ dia de armazenamento do produto;

5. A CCS não exerce influência no grau de proteólise do iogurte natural batido;

6. A CCS não apresenta efeitos sobre o crescimento dos microrganismos da cultura starter utilizada para a fabricação do iogurte natural batido. 


\section{REFERÊNCIAS BIBLIOGRÁFICAS}

ALLISON, J.R.D. Antibiotics residues in milk. British Veterinary Journal, v. 141, p. 9-16, 1995.

[APHA] AMERICAN PUBLIC HEALTH ASSOCIATION. Standard methods for the examination of dairy products. 16. ed. Washington: APHA, 1992.

ANDERSON, M. Source and significance of lysosomal enzymes in bovine milk fat globule membrane. Journal of Dairy Science, v. 60, p. 1217-1222, 1977.

ANDERSON, M. Factors affecting the distribution of lipoprotein lipase activity between serum and casein micelles in bovine milk. Journal of Dairy Research, v. 49, p. 51-59, 1982.

ANDERSON, M.; ANDREWS, A.T. Progressive changes in individual milk protein concentrations associated with high somatic cell counts. Journal of Dairy Research, v. 44, p. 223-235, 1977.

ANDREWS, A.T. Breakdown of caseins by proteinases in bovine milks with high somatic cell counts arising from mastitis or infusion with bacterial endotoxin. Journal of Dairy Research, v. 50, p. 57-66, 1983.

ANUÁRIO MILKBIZZ. 1999/2000. São Paulo: Milkbizz, 1999. 
[AOAC] ASSOCIATION OF OFFICIAL ANALYTICAL CHEMISTS. Official methods of analysis. 16. ed. Arlington, VA: AOAC, 1995.

AULDIST, M.J.; COATS, S.J.; ROGERS, G.L; McDOWELL, G.H Changes in the compositional of milk from normal and mastitic dairy cows during the lactation cycle. Australian Journal of Experimental Agriculture, v. 35, p. 427-436, 1995.

AULDIST, M.J.; COATS, S.J.; SUTHERLAND, B.J.; HARDHAM, J.F.; McDOWELL, G.H.; ROGERS, G.L. Effect of somatic cell count and stage of lactation on the quality and storage life of ultra high temperature milk. Journal of Dairy Research, v. 63, p. 377-386, 1996.

AULDIST, M.J.; HUBBLE, I.B. Effects of mastitis on raw milk and dairy products. Australian Journal of Dairy Technology, v. 53, p. 28-36, 1998.

AZZARA, C.D.; DIMIK, P.S. Leukocytes: a source of Lipolytic enzyme activity in normal and subclinically mastitic bovine milk. Journal of Dairy Science, v. 67, suppl. 1, p. 241, 1984.

AZZARA, C.D.; DIMIK, P.S. Lipoprotein lipase activity of milk from cows with prolonged subclinical mastitis. Journal of Dairy Science, v. 68, p. 3171-3175, 1985a.

AZZARA, C.D.; DIMIK, P.S. Lipolytic enzyme activity of macrophages in bovine mammary gland secretions. Journal of Dairy Science, v. 68, p. 1804-1812,1985b.

BACHMAN, K.C.; HAYEN, M.J.; MORSE, D.; WILCOX, C.J. Effect of pregnancy, milk yield, and somatic cell count on bovine milk fat hydrolysis. Journal of Dairy Science, v. 71, p. 925-931, 1988.

BALLOU, L.U.; PASQUINI, M.; BREMEL, R.D.; EVERSON, T.; SOMMER, D. Factors affecting herd milk composition and milk plasmin at four levels of somatic cell counts. Journal of Dairy Science, v. 78, p. 2186-2195, 1995. 
BARBANO, D.M.; RASMUSSEN, R.R.; LYNCH, J.M. Influence of milk SCC and milk age on cheese yield. Journal of Dairy Science, v. 74, p. 369-388, 1991.

BARRY, J.G.; DONNELLY, W.J. Casein compositional studies. II. the effect of secretory disturbance on casein composition in freshly drawn and aged bovine milks. Journal of Dairy Research, v. 48, p. 437-446, 1981.

BASTIAN, E.D.; BROWN, R.J. Plasmin in milk and dairy products: an update. International Dairy Journal, v. 6, p. 435-457, 1996.

BENEZECH, T.; MAINGONNAT, J.F. Characterization of the reological properties of yoghurt: a review. Journal of Food Engineering, v. 21, p. 447-472, 1994.

BIBALKE, D. The effect of high somatic cell count on the quality of dairy products. Dairy Food Sanitation, v. 4, p. 67-68, 1984.

BOBBIO, F.O.; BOBBIO, P.A. Manual de laboratório de química de alimentos. São Paulo: Varela, 1995. 129 p.

BRANDÃO, S.C.C. Tecnologia da produção industrial de iogurte. Leite e Derivados, v. 25, p. 24-38, 1995.

BRAMLEY, A. J. Current concepts on bovine mastitis. 4. ed. Arlington, VA: National Mastitis Council USA, 1996.

BROOKFIELD. More solutions to stick problems. Brookfield Engineering, Inc. [s.d.].

BROWN, R.J. Milk coagulation and protein denaturation. In: WONG, N.P.; JENNESS, R.; KEENEY, M.; MARTH, E.H. Fundamentals of dairy chemistry. 3. ed. New York: Van Nostrand Reinhold, 1988. p. 583-607 
CAFFIN, J.P.; POUTREL, B.; RAINARD, P. Physiological and pathological factors influencing bovine $\alpha$-lactoglobulin concentrations in milk. Journal of Dairy Science, v. 68, p. 1087-1094, 1985.

CARTIER, P.; CHILLIARD, Y. Spontaneous lipolysis in bovine milk: combined effects of nine characteristics in native milk. Journal of Dairy Science, v. 73, p. 1178-1186, 1990.

CASTBERG, H.B. Lipase activity. Bulletin of the International Dairy Federation, v. 271, p. 18-20, 1992.

CHENG, L.J.; CLARKE, P.T.; AUGUSTIN, M.A. Seasonal variation in yogurt properties. Australian Journal of Dairy Technology, v. 57, p. 187-191, 2002.

CHRISTEN, G.L.; NDOMBA, A.A.J. Evaluation of procedures to predict the keeping quality of ultra-high temperature processed skim milk. Journal of Dairy Science, $v$. 74, suppl. 1, p. 303, 1991.

COONEY, S.; TIERNAN, D.; JOYCE, P.; KELLY, A.L. Effect of somatic cell count and polymorphonuclear leucocyte content of milk on composition and proteolysis during ripening of Swiss-type cheese. Journal of Dairy Research, v. 67, p. 301-307, 2000.

DE RHAM, O.; ANDREWS, A.T. Qualitative and quantitative determination of proteolysis in mastitic milks. Journal of Dairy Science, v. 49, p. 587-596, 1982.

DEETH, H.C. Lipase activity and its effects on milk quality. Australian Journal of Dairy Technology, v. 48, p. 96-98, 1993.

DOWNEY, W.K. Review of the progress of dairy science: flavour impairment from pre- and post-manufacture lipolysis in milk and dairy products. Journal of Dairy Research, v. 47, p. 237-252, 1980. 
EL-DEEB, S.A.; HASSAN, H.N. Changes in the cow's milk composition as affected with mastitis infection. Alexandria Journal of Agricultural Research, v. 32, p. 163174, 1987.

ERWIN, R.E.; RANDOLPH, H.E. Influence of mastitis on properties of milk XI. fat globule membrane. Journal of Dairy Science, v. 58, p. 9-12, 1975.

FERNANDES, A.M.; OLIVEIRA, C.A.F.; TAVOLARO, P. The relationship between composition and somatic cell counts of milk from individual Holstein cows. Australian Journal of Dairy Technology, 2003. (submitted).

FIGUEIREDO, M.G.; PORTO, E. Avaliação do impacto da qualidade da matériaprima no processamento industrial do iogurte natural. Caderno Fazer Melhor, set./out., 2002. p. 76-80.

FITZ-GERALD, C.H.; DEETH, H.C.; KITCHEN, B.J. The relationship between the levels of free fatty acids, lipoprotein lipase, carboxylesterase, $N$-acetyl- $\beta$-Dglucosaminidase, somatic cell count and other mastitis indices in bovine milk. Journal of Dairy Research, v. 48, p. 253-265, 1981.

FOOD AND AGRICULTURE ORGANIZATION Disponível em <http://www. fao.org> Acesso em 16/10/2003.

FONSECA, L.F.L.; SANTOS, M.V. Contagem de células somáticas. In: Qualidade do leite e controle de mastite, São Paulo: Lemos, 2000. p. 44-58.

FOX, P.F.; GUINEE, T.P.; COGAN, T.M.; McSWEENEY, P.L.H. Fundamentals of cheese science. New York: Aspen, 2000. 587 p.

GACULA, J.R.; SINGH, J. Statistical methods in food and consumer research. Orlando: Academic, 1984. 
GASSEM, M.; FRANK, J.F. Effect of protein degradation of milk on the physical and chemical properties of yogurt. Journal of Dairy Science, v. 73, suppl. 1, p. 114, 1990.

GASSEM, M.; FRANK, J.F. Physical properties of yogurt made from milk treated with proteolytic enzymes. Journal of Dairy Science, v. 74, p. 1503-1511, 1991.

GRANDISON, A.S.; FORD, G.D. Effects of variations in somatic cell count on the rennet coagulation properties of milk and on the yield, composition and quality of cheddar cheese. Journal of Dairy Research, v. 53, p. 645-655, 1986.

GRIEVE, P.A.; KITCHEN, B.J. Proteolysis in milk: the significance of proteinases originating from milk leucocytes and a comparison of the action of leucocyte, bacterial and natural milk proteinases on casein. Journal of Dairy Research, v. 52, p. 101-112, 1985.

HAENLEIN, G.F.W.; SCHULTZ, L.H.; ZIKAKIS, J.P. Composition of proteins in milk with varying leucocyte contents. Journal of Dairy Science, v. 56, p. 1017-1024, 1973.

HELLINGA, C.; SOMSEN, D.J.; KOENRAADS, J.P.J.M. Viscosity of stirred yogurt: modern techniques useful in analysing and improving routine measurements. Netherlands Milk Dairy Journal, v. 40, p. 217-240, 1986.

INSTITUTO ADOLFO LUTZ. Normas analíticas do Instituto Adolfo Lutz, 1. 3. ed. São Paulo: IAL, 1985.

[IDF] INTERNATIONAL DAIRY FEDERATION. Bovine mastitis: definition and guidelines for diagnosis. Bulletin of International Dairy Federation, v. 211, p. 7 , 1987.

JURCZAK, M.E.; SCIUBISZ, A. Studies on the lipolytic changes in milk from cows with mastitis. Milchwissenschaft, v. 36, p. 217-219, 1981. 
KITCHEN, B.J. Review of the progress of dairy science: bovine mastitis: milk compositional changes and related diagnostic tests. Journal of Dairy Research, v. 48, p. 167-188, 1981.

KLEI, L.; YUN, J.; SAPRU, A.; LYNCH, J.; BARBANO, D.M.; SEARS, P.; GALTON, D. Effects of milk SCC on Cottage cheese yield and quality. Journal of Dairy Science, v. 81, p. 1205-1213, 1998.

KOHLMANN, K.L.; NIELSEN, S.S.; LADISCH, M.R. Effects of a low concentration of added plasmin on ultra-high temperature processed milk. Journal of Dairy Science, v. 74, p. 1151-1156, 1991.

KORYCKA-DAHL, M.; RIBADEAU DUMAS, B.; CHENE, N.; MARTAL, J. Plasmin activity in milk. Journal of Dairy Science, v. 66, p. 704-711, 1983.

KROGER, M. Quality of yogurt. Journal of Dairy Science, v. 59, p. 344-50, 1976.

LARANJA, L.F.; AMARO, F. Contagem de células somáticas: conceitos e estratégias de controle. Balde Branco, v. 35, p. 28-34, 1998.

LE ROUX, Y.; COLIN, O.; LAURENT, F. Proteolysis in samples of quarter milk with varying somatic cell counts. 1. comparison of some indicators of endogenous proteolysis in milk. Journal of Dairy Science, v. 78, p. 1289-1297, 1995.

LEE, S.J.; SHERBON, J.W. Chemical changes in bovine milk fat globule membrane caused by heat treatment and homogeneization of whole milk. Journal of Dairy Research, v. 69, p. 555-567, 2002.

LEWIS, M.J. Physical properties of dairy products. In: Robinson, R.K. Modern Dairy Technology, 2. ed. London, Chapman \& Hall, 1993. p. 331-380,

LYNCH, J.M.; BARBANO, D.M. Indirect and direct determination of the casein content of milk by Kjeldahl nitrogen analysis: collaborative study. Journal AOAC International, v. 81, p. 763-774, 1998. 
MA, Y.; RYAN, C.; BARBANO, D.M.; GALTON, D.M.; RUDAN, M.A.; BOOR, K.J. Effects of somatic cell count on quality and shelf-life of pasteurized fluid milk. Journal of Dairy Science, v. 83, p. 264-274, 2000.

MACHADO, P.F.; BARANCELLI, G.; RIBEIRO, A. CCS: leite com mais qualidade e melhor rendimento industrial. Indústria de laticínios, 2, p. 65-68, 1998.

MARQUES, L.T.; BALBINOTTI, M.; FISCHER, V. Variations in the milk chemical composition according to somatic cell count. In: PANAMERICAN CONGRESS ON MILK QUALITY AND MASTITIS CONTROL, 2., 2002, Ribeirão Preto, Brazil.

MILKPOINT. Disponível em www.milkpoint.com.br. Acesso em 19/10/2002.

MILLER, R.H.; EMANUELSSON, U.; PERSSON, E.; BROLUND, L.; PHILIPSSON, J.; FUNKE,H. Relationships of somatic cell counts to daily milk yield and composition. Acta Agriculturae Scandinavica, v. 33, p. 209-223, 1983.

MINISTÉRIO DAAGRICULTURA. Regulamento da inspeção industrial e sanitária de produtos de origem animal. Brasília: MA, 1980.

MINISTÉRIO DA AGRICULTURA. Instrução normativa $n$. 51, de 18 de setembro de 2002. Disponível em www.agricultura.gov.br/sda/dipoa/index.htm. Acesso em 24/10/2003.

MINISTÉRIO DA SAÚDE. Agência Nacional de Vigilância Sanitária. Resolução $\operatorname{RDC} n^{0}$ 12, de 02 de janeiro de 2001. [Aprova o Regulamento Técnico sobre Padrões Microbiológicos para Alimentos]. Diário Oficial da União, Seção I, Brasília, 02 de janeiro de 2001.

MITCHELL,G.E.; FEDRICK, I.A.; ROGERS, S.A. The relationship between somatic cell count, composition and manufacturing properties of bulk milk. 2. cheddar cheese from farm bulk milk. Australian Journal of Dairy Technology, v. 41, p. 12-14, 1986. 
MOTTAR, J.; BASSIER, A.; JONIAU, M.; BAERT, J. Effect of heat-induced association of whey proteins and casein micelles on yoghurt texture. Journal of Dairy Science, v. 72, p. 2247-2256, 1989.

MUIR, D.D. The shelf-life of dairy products: 1 . factors influencing raw milk and fresh products. Journal of the Society of Dairy Technology, v. 49, p. 24-32, 1996.

MUNRO, G.L.; GRIEVE, P.A.; KITCHEN, B.J. Effects of mastitis on milk yield, milk composition, processing properties and yield and quality of milk products. Australian Journal of Dairy Technology, v. 39, p. 7-16, 1984.

MURPHY, S.C.; CRANKER, K.; SENYK, G.F.; BARBANO, D.M.; SAEMAN, A.I.; GALTON, D.M. Influence of bovine mastitis on lipolysis and proteolysis in milk. Journal of Dairy Science, v. 72, p. 620-626, 1989.

NEEDS, E.C.; ANDERSON, M. Lipid composition of milks from cows with experimentally induced mastitis. Journal of Dairy Research, v. 51, p. 239-249, 1984.

NEEDS, E.C.; ANDERSON, M.; MORANT, S.V. Interaction of factors which influence the extent of lipolysis during milking and storage of raw milk. Journal of Dairy Research, v. 53, p. 203-210, 1986.

NEVILLE, M.C.; WATTERS, C.D. Secretion of calcium into milk: review. Journal of Dairy Science, v. 66, p. 371-380, 1983.

NICKERSON, S.C. Bovine mammary gland: structure and function; relationship to milk production and immunity to mastitis. Agri-Practice, v. 15, p. 11-18, 1994.

OKELLO-UMA, I.; MARSHALL, V.M.E. Influence of mastitis on growth of starter organisms used for the manufactured of fermented milks. Journal of Dairy Research, v. 53, p. 631-637, 1986.

OLIVEIRA, C.A.F.; FERNANDES, A.M.; CUNHA NETO, O.C.; FONSECA, L.F.L.; SILVA, E.O.T.; BALIAN, S.C. Composition and sensory evaluation of whole yogurt 
produced from milk with different somatic cell count. Australian Journal of Dairy Technology, v. 57, p. 192-196, 2002.

OLIVEIRA, C.A.F.; FONSECA, L.F.L.; GERMANO, P.M.L. Fatores relacionados à produção que influenciam a qualidade do leite. Higiene Alimentar, v. 13, p. 10-16, 1999.

PACKARD, V.S.; GINN, R.E. Interelationships between select quality test and levels of milk components. Dairy, Food and Environmental Sanitation, v. 11, p. 577-81, 1991.

PELEGRINE, D.H.; VIDAL, J.R.M.B.; GASPARETTO, C.A. Estudo da viscosidade aparente das polpas de manga (Keitt) e abacaxi (Pérola). Ciência e Tecnologia de Alimentos, v. 20, n. 1, p. 128-31, 2000.

PENNA, A.L.B.; BARUFFALDI, R.; OLIVEIRA, M.N. Análise da consistência do iogurte: comparação entre medida instrumental e sensorial. In: CONGRESSO BRASILEIRO DE CIENNCIA E TECNOLOGIA DE ALIMENTOS, 1996, Campinas, SBTA.

PHILPOT, W.N. Milk quality and mastitis control: past, present and future. In: PANAMERICAN CONGRESS ON MILK QUALITY AND MASTITIS CONTROL, 2., 2002, Ribeirão Preto.

PHILPOT, W.N.; NICKERSON, S.C. Origem e significado das células somáticas. In: Vencendo a luta contra a mastite. Naperville: Milkbizz, 2002. p. 28-37.

POLITIS, I.; BARBANO, D.M.; GOREWIT, R.C. Distribution of plasminogen and plasmin in fractions of bovine milk. Journal of Dairy Science, v. 75, p. 1402-1410, 1992.

POLITIS, I.; NG-KWAI-HANG, K.F. Effects of somatic cell counts and milk composition on cheese composition and cheese making efficiency. Journal of Dairy Science, v. 71, p. 1711-1719, 1988a. 
POLITIS, I.; NG-KWAI-HANG, K.F. Effects of somatic cell counts and milk composition on the coagulating properties of milk. Journal of Dairy Science, v. 71, p. $1740-1746,1988 b$.

POLITIS, I.; NG-KWAI-HANG, K.F.; GIROUX, R.N. Environmental factors affecting plasmin activity in milk. Journal of Dairy Science, v. 72, p. 1713-1718, 1989.

POUTREL, B.; CAFFIN, J.P.; RAINARD, P. Physiological and pathological factors influencing bovine serum albumin content of milk. Journal of Dairy Science, v. 66, p. 535-541, 1983.

RANDOLPH, H.E.; ERWIN, R.E. Influence of mastitis on properties of milk. X. fatty acid composition. Journal of Dairy Science, v. 57, p. 865-869, 1974.

RANDOLPH, H.E.; ERWIN, R.E.; RICHTER, R.L. Influence of mastitis on properties of milk. VII. Distribution of milk proteins. Journal of Dairy Science, v. 57, p. 15-18, 1974.

RENEAU, J.K.; PACKARD, V.S. Monitoring mastitis, milk quality and economic losses in dairy fields. Dairy, Food and Environmental Sanitation, v. 11, p. 4-11, 1991.

RICHARDSON, B.C. The proteinases of bovine milk and the effect of pasteurization on their activity. New Zealand Journal of Dairy Science and Technology, v. 18, p. 233-245, 1983.

ROBINSON, R.K.; TAMIME, A.Y. Manufacture of yogurt and other fermented milks. In: Robinson, R.K.. Modern dairy technology. 2. ed. London: Chapman \& Hall, 1993. p. 1-47.

ROGERS, S.A.; MITCHELL, G.E. The relationship between somatic cell count, composition and manufacturing properties of bulk milk 6 . cheddar cheese and skim milk yoghurt. Australian Journal of Dairy Technology, v. 49, p. 70-74, 1994. 
ROGERS, S.A.; SLATTERY, S.L.; MITCHELL, G.E.; HIRST, P.A.; GRIEVE, P.A. The relationship between somatic cell count, composition and manufacturing properties of bulk milk 3. individual proteins. Australian Journal of Dairy Technology, v. 44, p. 49-52, 1989a.

ROGERS, S.A.; MITCHELL, G.E.; BARTLEY, J.P. The relationship between somatic cell count, composition and manufacturing properties of bulk milk 4. non-protein constituents. Australian Journal of Dairy Technology, v. 44, p. 49-52, 1989b.

ROHM, H. Viscosity determination of stirred yoghurt. Lebensm.-Wiss. U.-Technol., v. 25, p. 297-301, 1992.

SAEMAN, A.I.; VERDI, R.J.; GALTON, D.M. Effect of mastitis on proteolytic activity in bovine milk. Journal of Dairy Science, v. 71, p. 505-512, 1988.

SALIH, A.M.A.; ANDERSON, M. Observations on the influence of high cell count on lipolysis in bovine milk. Journal of Dairy Research, v. 46, p. 453-462, 1979.

SANTOS, M.V.; MA, Y.; BARBANO, D.M. Effect of somatic cell count on proteolysis and lipolysis in pasteurized fluid milk during shelf-life storage. Journal of Dairy Science, v. 86, p. 2491-2503, 2003a.

SANTOS, M.V.; MA, Y.; CAPLAN, Z.; BARBANO, D.M. Sensory threshold of offflavors caused by proteolysis and lipolysis in milk. Journal of Dairy Science, v. 86, p. $1601-1607,2003 b$.

SAS Institute. SAS ${ }^{\circledR}$ user's guide: statistics. Cary, NC: SAS Institute Inc., 1992.

SCHULTZ, L.H. Somatic cell in milk: physiological aspects and relationship to amount and composition of milk. Journal of Food Protection, v. 40, p. 125-131, 1977.

SENYK, G.F.; BARBANO, D.M.; SHIPE, W.F. Proteolysis in milk associated with increasing somatic cell counts. Journal of Dairy Science, v. 68, p. 2189-2194, 1985. 
SHAAR, J.; FUNKE, H. Effect of subclinical mastitis on milk plasminogen and plasmin compared with that on sodium, antitrypsin and $N$-acetyl- $\beta-D$ glucosaminidase. Journal of Dairy Research, v. 53, p. 515-528, 1986.

SHAKER, R.R.; JUMAH, R.Y.; ABU-JDAYIL, B. Rheological properties of plain yogurt during coagulation process: impact of fat content and preheat treatment of milk. Journal of Food Engineering, v. 44, p. 175-180, 2000.

SHARMA, K.K.; RANDOLPH, H.E. Influence of mastitis on properties of milk: VIII. distribution of soluble and micellar casein. Journal of Dairy Science, v. 57, p. 19-23, 1974.

SHIPE, W.F.; SENYK, G.F. Effects of processing conditions on lipolysis in milk. Journal of Dairy Science, v. 64, p. 2146-2149, 1981.

SHIPE, W.F.; SENYK, G.F.; FOUNTAIN, K.B. Modified copper soap solvent extraction for measuring free fatty acids in milk. Journal of Dairy Science, v. 63, p. 193-198, 1980.

SHUSTER, D.E.; HARMON, R.J.; JACKSON, J.A.; HEMKEN, R.W. Suppression of milk production during endotoxin-induced mastitis. Journal of Dairy Science, v. 74, p. 3763-3774, 1991.

SINGH, L.N.; GANGULI, N.C. Alterations in the micellar, soluble and other casein fractions in the abnormal bovine milk secretions. Indian Journal of Dairy Science, v. 28, p. 151-158, 1975.

SOMERS, J.M.;O'BRIEN, B.; MEANEY, W.J.; KELLY, A.L. Heterogeneity of proteolytic enzyme activities in milk samples of different somatic cell count. Journal of Dairy Research, v. 70, p. 45-50, 2003.

SOUZA, G. Fatores de qualidade do iogurte. Coletânea do Instituto de Tecnologia de Alimentos, v. 21, p. 20-27, 1991. 
SPREER, E. Lactologia industrial. 2. ed., Zaragoza: Acribia, 1991. 617 p.

SUNDHEIN, G.;BENGTSSON-OLIVECRONA, G. Isolated milk fat globule as substrate for lipoprotein lipase: study of factors relevant to spontaneous lipolysis in milk. Journal of Dairy Science, v. 70, p. 499-505, 1987.

TALLAMY, P.T.; RANDOLPH, H.E. Influence of mastitis on properties of milk. IV. hydrolytic rancidity. Journal of Dairy Science, v. 52, p. 1569-1572, 1969.

TALLAMY, P.T.; RANDOLPH, H.E. Influence of mastitis on properties of milk. V. total and free concentrations of major minerals in skim milk. Journal of Dairy Science, $v$. 53, p. 1386-1388, 1970.

TAMIME, A.Y;; DEETH, H.C. Yogurt: technology and biochemistry. Journal of Food Protection, v. 43, p. 937-977, 1980.

TAMIME, A.Y.; ROBINSON, R.K. Fermented milks and their future trends. part II. technological aspects. Journal of Dairy Research, v. 55, p. 281-307, 1988.

TAMIME, A.Y.; ROBINSON, R.K. Yogur: ciencia y tecnología. Zaragoza: Acribia, 1991. $368 \mathrm{p}$.

URECH, E.; PUHAN, Z.; SCHÄLLIBAUM, M. Changes in milk protein fraction as affected by subclinical mastitis. Journal of Dairy Science, v. 82, p. 2402-2411, 1998.

VARNAM, A.H.; SUTHERLAND, J.P. Leches fermentadas. In: Leches y productos lácteos. Zaragoza: Acribia, 1994. 476 p.

VERDI, R.J.; BARBANO, D.M.; DELLAVALLE, M.E.; SENYK, G.F. Variability in true protein, casein, nonprotein nitrogen, and proteolysis in high and low somatic cell milks. Journal of Dairy Science, v. 70, p. 230-242, 1987. 
VERDI, R.J.; BARBANO, D.M. Preliminary investigation of the properties of somatic cell proteases. Journal of Dairy Science, v. 71, p. 534-538, 1988.

VERDI, R.J.; BARBANO, D.M. Properties of proteases from milk somatic cells and blood leucocytes. Journal of Dairy Science, v. 74, p. 2077-2081, 1991a.

VERDI, R.J.; BARBANO, D.M. Effect of coagulants, somatic cell enzymes, and extracellular bacterial enzymes on plasminogen activation. Journal of Dairy Science, v. 74, p. 772-782, 1991b.

WEAVER, J.C.; KROGER, M. Protein, casein and noncasein protein percentages in milk with high somatic cell counts. Journal of Dairy Science, v. 60, p. 878-881, 1976.

WOLFSCHOON-POMBO, A.F.; GRANZINOLLI, G.G.M.; FERNANDES, R.M. Sólidos totais do leite, acidez, $\mathrm{pH}$ e viscosidade do iogurte. Revista do Instituto de Laticínios Cândido Tostes, v. 38, p. 19-24, 1983.

ZACHOS, T.; POLITIS, J.; GOREWIT, R.C.; BARBANO, D.M. Effect of mastitis on plasminogen activator activity of milk somatic cells. Journal of Dairy Research, $v$. 59, p. 461-467, 1992. 